
of Engineers ${ }_{\circledast}$

Engineer Research and Development Center

\title{
Simulation of Vegetation Recovery from Military Disturbances on Fort Bliss
}

Tamara Hochstrasser, Debra Peters,

November 2005

and Jeffrey S. Fehmi

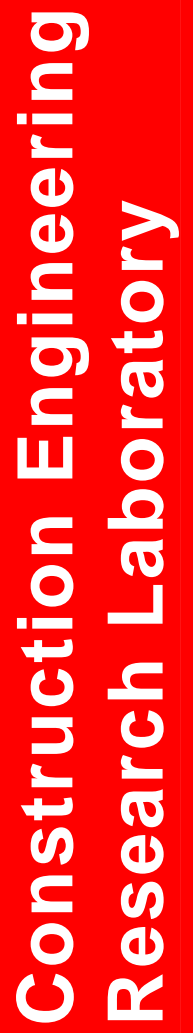




\section{Simulation of Vegetation Recovery from Military Disturbances on Fort Bliss}

Tamara Hochstrasser and Debra Peters

USDA-ARS Jornada Experimental Range

Box 30003, MSC 3 JER

New Mexico State University

Las Cruces, NM 88003

Jeffrey S. Fehmi

Construction Engineering Research Laboratory

PO Box 9005

Champaign, IL 61826-9005

Approved for public release; distribution is unlimited.

Prepared for U.S. Army Corps of Engineers

Washington, DC 20314-1000 


\section{ABSTRACT}

This report covers two years of work by the Jornada Experimental Range Department at New Mexico State University and the U.S.Army ERDC/CERL. The overall goal of the project was to enhance the vegetation simulation modeling capabilities of Fort Bliss, Texas, for evaluating the effects of military disturbances on arid land vegetation. The aim of this work was to mechanistically predict shifts from one community type to another by determining primary linkages between community types.

DISCLAIMER: The contents of this report are not to be used for advertising, publication, or promotional purposes. Citation of trade names does not constitute an official endorsement or approval of the use of such commercial products. All product names and trademarks cited are the property of their respective owners. The findings of this report are not to be construed as an official Department of the Army position unless so designated by other authorized documents. 


\section{CONTENTS}

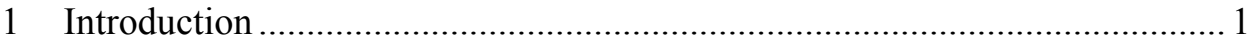

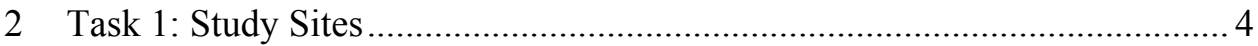

Identification of site-level data................................................................. 4

Description and comparison of sites....................................................... 7

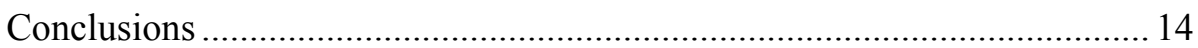

3 Task 2. Ecological characteristics of dominant species .............................. 14

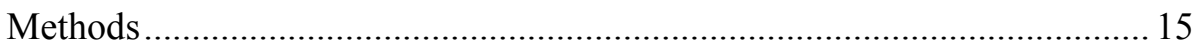

Differences between grasses and shrubs ................................................... 16

Species characteristics of the dominants .................................................... 17

4 Task 3. Conceptual model of disturbances in shrublands versus grasslands. 20

5 Task 4. Simulation model used: ECOTONE................................................ 21

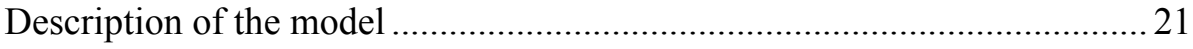

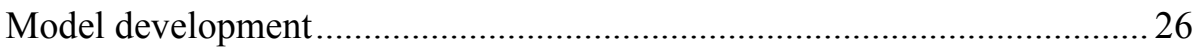

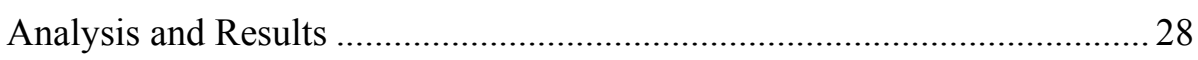

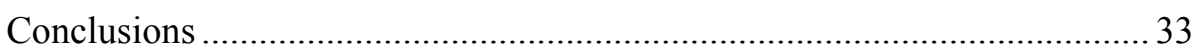

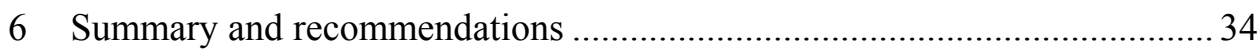

Research needs and recommendations .......................................................... 34

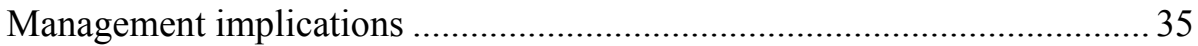

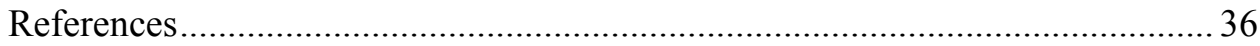

Appendix A. Keywords for literature database on dominant species at the Jornada

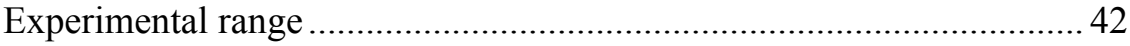

Appendix B. Species characteristics of the dominant species at the Jornada

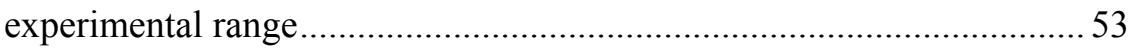

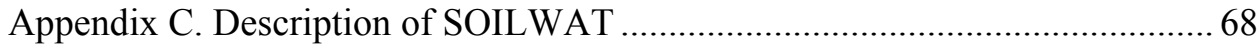

Appendix D. Trampling disturbance routine developed for ECOTONE............. 76 


\section{ILLUSTRATIONS}

Figure 1. Conceptual model of linkages between community types .................... 2

Figure 2. Vegetation map of the Jornada Experimental Range and the Chihuahuan Desert Rangeland Research Center ......................................5

Figure 3. Major vegetation types of the Jornada Experimental Range and the Chihuahuan Desert Rangeland Research Center ................................9

Figure 4. Comparison of the climate patterns in each season with the long-term average precipitation .................................................... 9

Figure 5. Vegetation map of Fort Bliss ............................................................ 10

Figure 6. Soils map of Fort Bliss .................................................................... 14

Figure 7. Climate data from weather stations near Fort Bliss ........................... 13

Figure 8. Comparison of weather data from Fort Bliss and the JES ................... 18

Figure 9. Soil properties by depth of five vegetation types at the Jornada ......... 18

Figure 10. Conceptual model of disturbances in grasslands and shrublands.........20

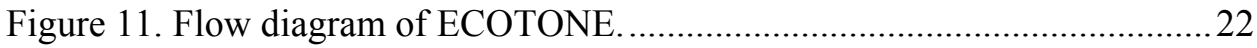

Figure 12. Root distribution of shallow-rooted grasses ....................................2 24

Figure 13. Variation of transpiration with amount of above-ground

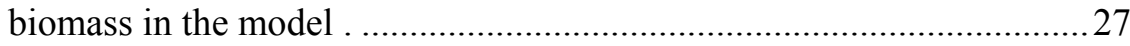

Figure 14. Temperature effect on plant activity and transpiration ...................... 31

Figure 15. Model output: Recovery after a range of disturbance intensities of individual black grama and mesquite plants .................... 32

Figure 16. Recovery after a disturbance of high intensity

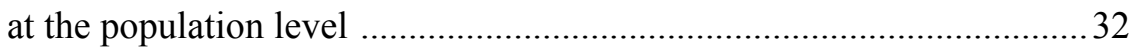

\section{TABLES}

Table 1. Elevational range of the five main vegetation types at the Jornada

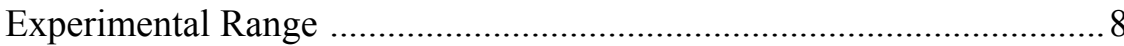

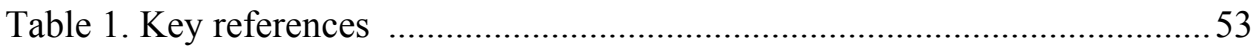

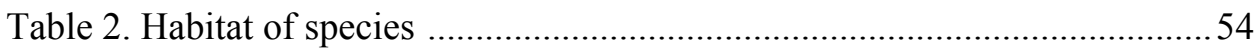

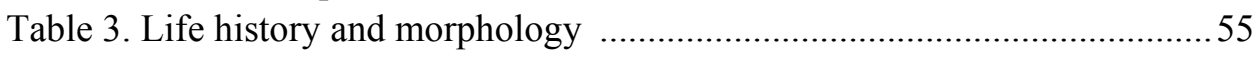

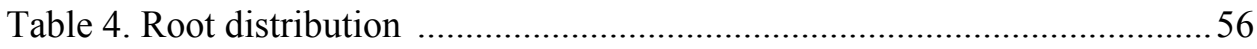

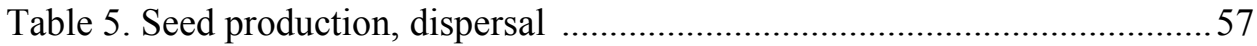

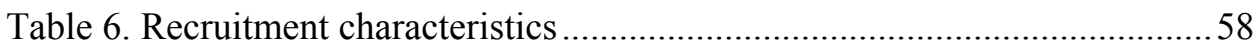

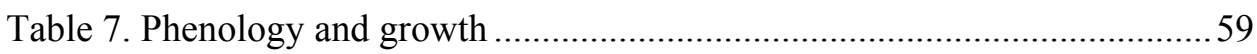




\section{PREFACE}

This study was conducted for the Office of the Directorate of Environmental Programs (DAIM), Assistant Chief of Staff (Installation Management) (ACS[IM]) under project 622720896, "Environmental Quality Technology"; Work Unit CNN-T081. The technical monitor was Dr. Vic Diersing, DAIM-EDN.

The Construction Engineering Research Laboratory (CERL) Principal Investigator was Dr. Jeffrey S. Fehmi. The managers at Fort Bliss were Kevin vonFinger and Brett Russell. The work was performed under contract by Debra P. C. Peters and Tamara Hochstrasser in association with New Mexico State University and USDA-ARS Jornada Experimental Range. The technical editor was Gloria J. Wienke, Information Technology Laboratory. Mr. Stephen Hodapp is Chief, CEERD-CN-N, and Dr. John T. Bandy is Chief, CEERD-CN. The associated Technical Director was Dr. William D. Severinghaus, CEERD-CV-T. The Director of CERL is Dr. Alan W. Moore.

CERL is an element of the U.S. Army Engineer Research and Development Center (ERDC), U.S. Army Corps of Engineers. The Commander and Executive Director of ERDC is COL John Morris III, EN and the Director of ERDC is Dr. James R. Houston. 


\title{
Simulation of Vegetation Recovery from Military Disturbances on Fort Bliss
}

\author{
TAMARA HOCHSTRASSER, DEBRA P.C. PETERS, AND JEFFREY S. FEHMI
}

\section{INTRODUCTION}

This report covers two years of work by the Jornada Experimental Range Department at New Mexico State University and the U.S. Army ERDC/CERL. The overall goal of the project was to enhance the vegetation simulation modeling capabilities of Fort Bliss, Texas, for evaluating the effects of military disturbances on arid land vegetation. The project, conducted by the Jornada Experimental Range (JER), where research on arid land vegetation dynamics has been conducted for 90 years, was crucial to transferring scientific knowledge on vegetation dynamics to Fort Bliss.

The aim of this contract work was to mechanistically predict shifts from one community type to another by determining primary linkages between community types. Both community types and linkages between community types can be defined in different ways. For the purposes of this project, we use the following definitions:

Community type: A community was defined based on the most important plant species ( $>50 \%$ of total cover). A shift from one community type to another was defined as a shift in the composition of plant species that constitute $>50 \%$ of the total cover of the vegetation. This definition has become more acceptable in ecological research, as the biotic structure of ecosystems is predominantly due to the presence of plants, the majority of which belong to the dominant plant species (by definition).

Linkages between community types: Community types are linked by mortality and recruitment events of dominant plants. A decrease in the population of one dominant species and an increase in the population of another one was defined as a shift in community type as defined above (Fig. 1). In arid environments, mortality and recruitment events of plants are affected by water availability, seed dispersal, competition with existing vegetation, and disturbance. 


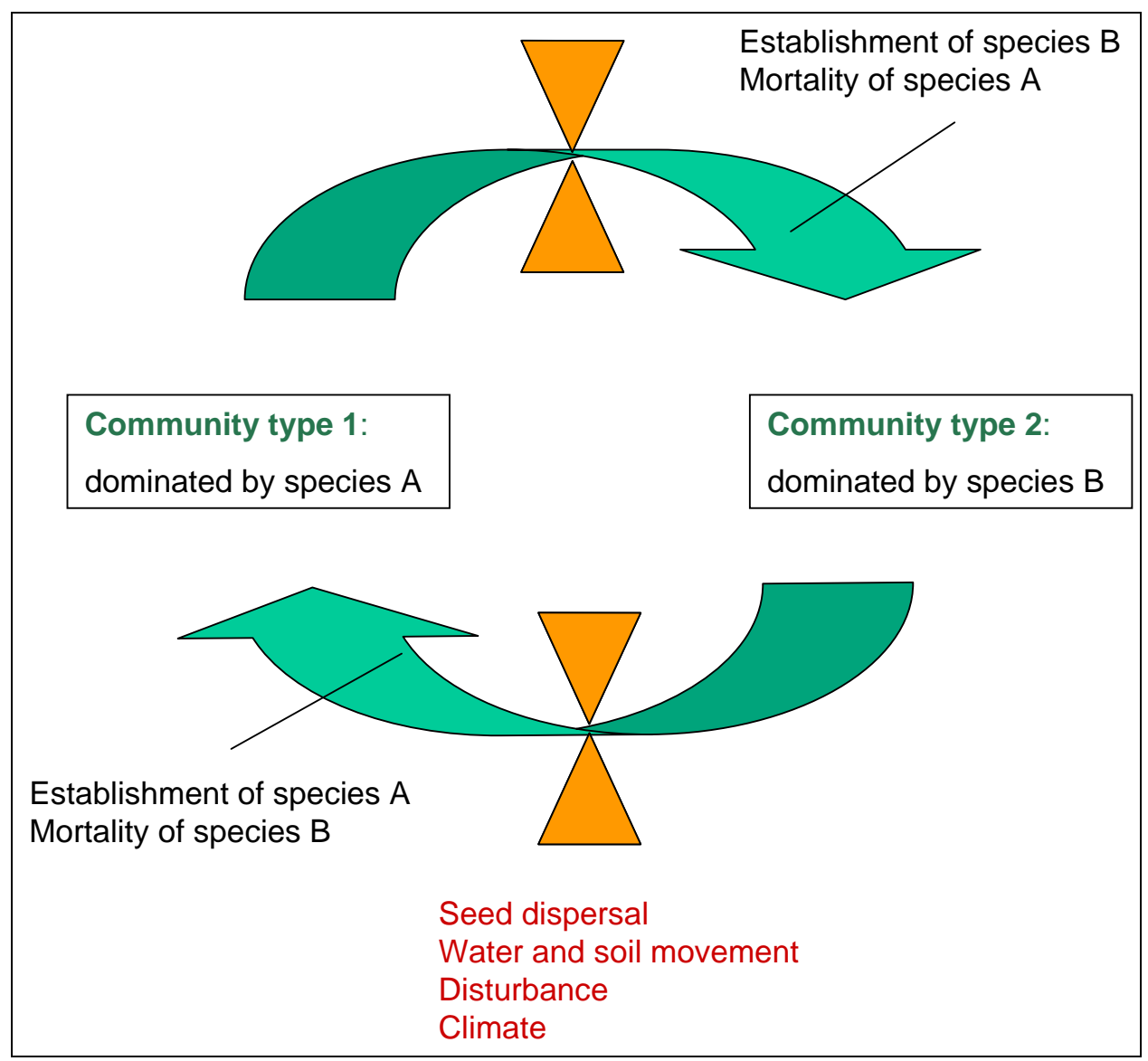

Figure 1. Conceptual model of linkages between community types.

While the ultimate goal of this project was to predict transitions between all community types, the primary focus was to predict shifts between grass- and shrub-dominated systems. A shift in the dominant lifeform leads to more significant ecological changes in the system than a shift between dominant species of the same lifeform (Archer et al. 2001). In arid ecosystems, a shift in the dominant lifeform affects water dynamics (Schlesinger et al. 1990), leads to a redistribution of nutrients in the landscape (Schlesinger et al. 1990; Schlesinger et al. 1996), and influences functional group composition of subdominant plant species (Hochstrasser and Peters, submitted). Furthermore, the distribution and abundance of animals in the ecosystem may also be affected (Parmenter and MacMahon 1983; Whitford 1997; Pidgeon et al. 2001). Therefore, disturbances that alter the dominance from grasses to shrubs (or vice versa) affect the system more fundamentally than disturbances under which the system maintains the dominant lifeform. For the purposes of this project, it was therefore important to understand the ecological mechanisms that change the dominant lifeform, and how human-induced disturbances can influence these mechanisms. 
The three major objectives for understanding and minimizing the ecological impacts of military training activities are compliance with the law, maintenance of the landscape for effective training, and reduction of off-site environmental pollution (Goran et al. 1983). The laws that regulate the management of ecological impacts on military lands are the National Environmental Policy Act (NEPA), Army Regulations 200-285, and the Endangered Species Act. Military training is less effective if there is a lack of cover for people and vehicles, and if severe environmental degradation reduces the trainability of the area. Dust from the training area may potentially impact the air quality of communities downwind, and sediment in streams eroded from degraded land may affect water quality downstream.

Recovery from disturbance in arid lands generally takes a long time. In the Mojave Desert, recovery from soil compaction in abandoned mining town sites can take over 100 years (Webb et al. 1986). Mechanisms for recovery of compacted soil could be freezing and thawing cycles and the activity of termites (Taylor Soltero 1996). For managing arid lands, it is crucial to estimate recovery times from disturbances. Generally, estimating recovery time of the vegetation has been done using linear extrapolation (Lathrop 1983; Webb et al. 1986). However, recovery dynamics may not be linear over time, and a process-based approach to extrapolation may be more insightful. The goal of this project was to provide process-based approximations of recovery times from disturbances of desert grasslands and shrublands.

A previous effort at creating a simulation model for evaluating the effects of military disturbances on vegetation at Fort Bliss was the EDYS model (Childress et al. 2002). This model focused at the landscape scale but incorporated a multilevel spatial nesting structure from the plant to the plot to the landscape. The relative performance of individual plants given a certain climate and disturbance regime was evaluated at the plant scale. The composition of the vegetation at the plot scale was then translated into a vegetation type. Once the vegetation composition sufficiently changed, the plot shifted to a new vegetation type. The authors of this model concluded that it is the combination of grazing, drought or fire suppression, and military training that makes it difficult for the vegetation to recover from military disturbances. Our goal was to provide an alternative modeling approach using an individual-plant-based model (ECOTONE) developed for arid and semiarid ecosystems (Peters 2002). 


\section{TASK 1: STUDY SITES}

The first task was to determine similarities in major plant communities and soil properties between Ft. Bliss and the JER and to quantitatively identify those plant communities that are most similar between sites.

\section{Identification of site-level data}

Identifying site-level data was not easy at either site, although we had more support for finding data on the Jornada Experimental Range. A list of long-term data sets from the JER was compiled by D.P.C. Peters in connection with other projects (http://usda-ars.nmsu.edu/data-info/data_index.htm). For each site, we were interested in identifying soils, vegetation, and climate information.

\section{Jornada Experimental Range}

The vegetation types at the JER are well described. There is a vegetation map that was created in 1998 by R.P. Gibbens (Fig. 2). It is common in semi-arid areas that vegetation types are strongly dominated by just one species. Based on the first dominant species, five major vegetation types have been identified: two grassland types and three shrubland types (Fig. 3). The two grassland types are dominated by tobosa (Pleuraphis mutica) for playa grasslands and black grama (Bouteloua eriopoda) for upland grasslands. The shrubland types are dominated by honey mesquite (Prosopis glandulosa), creosotebush (Larrea tridentata), and tarbush (Flourensia cernua). There are a few shrublands at the JER that are dominated by a variety of other species, but none of these shrub species is dominant in a very big area, so vegetation types dominated by these species are not recognized separately. Amongst the mesquite shrublands, R.P. Gibbens distinguished three types (mesquite shrublands, mesquite dunelands, and mesquite sandhills) according to the heights of the sandy hummocks formed around the base of the shrubs. For this project, we focused on mesquite shrublands that have not yet formed significant hummocks around the base of the shrub, since the hydrological implications of dune formation are not completely understood.

Soils information for the JER is available at the landscape scale. The soil conservation survey of Dona Ana county lists only ten major soil associations for the JER (Bulloch and Neher 1980). Out of these ten, four soil associations cover the majority of the area [the Onite-Pintura complex (OR), the Wink-Pintura complex (WP), the Dona Ana-Reagan Association (DR), and the SimonaHarrisburg association (SH)]. The others are OP, ST, BJ, NU, BK, WH. Three of these minor soil types (NU, OP, WH) cover the majority of the area at the 


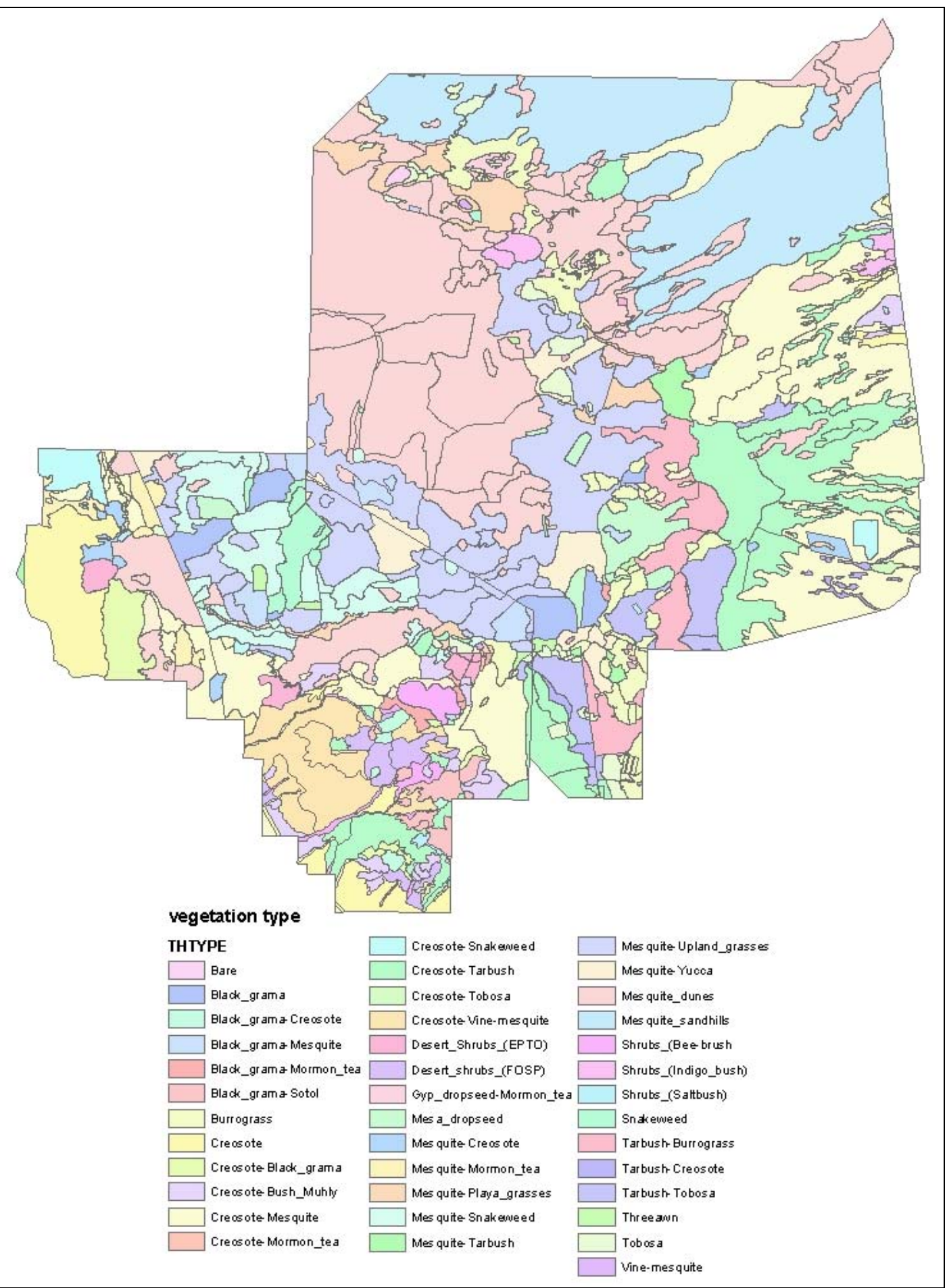

Figure 2. Vegetation map of the Jornada Experimental Range and the Chihuahuan Desert Rangeland Research Center. (Unpublished data by R.P. Gibbens, figure by D.P.C. Peters DACA42-01-P-0160.) 


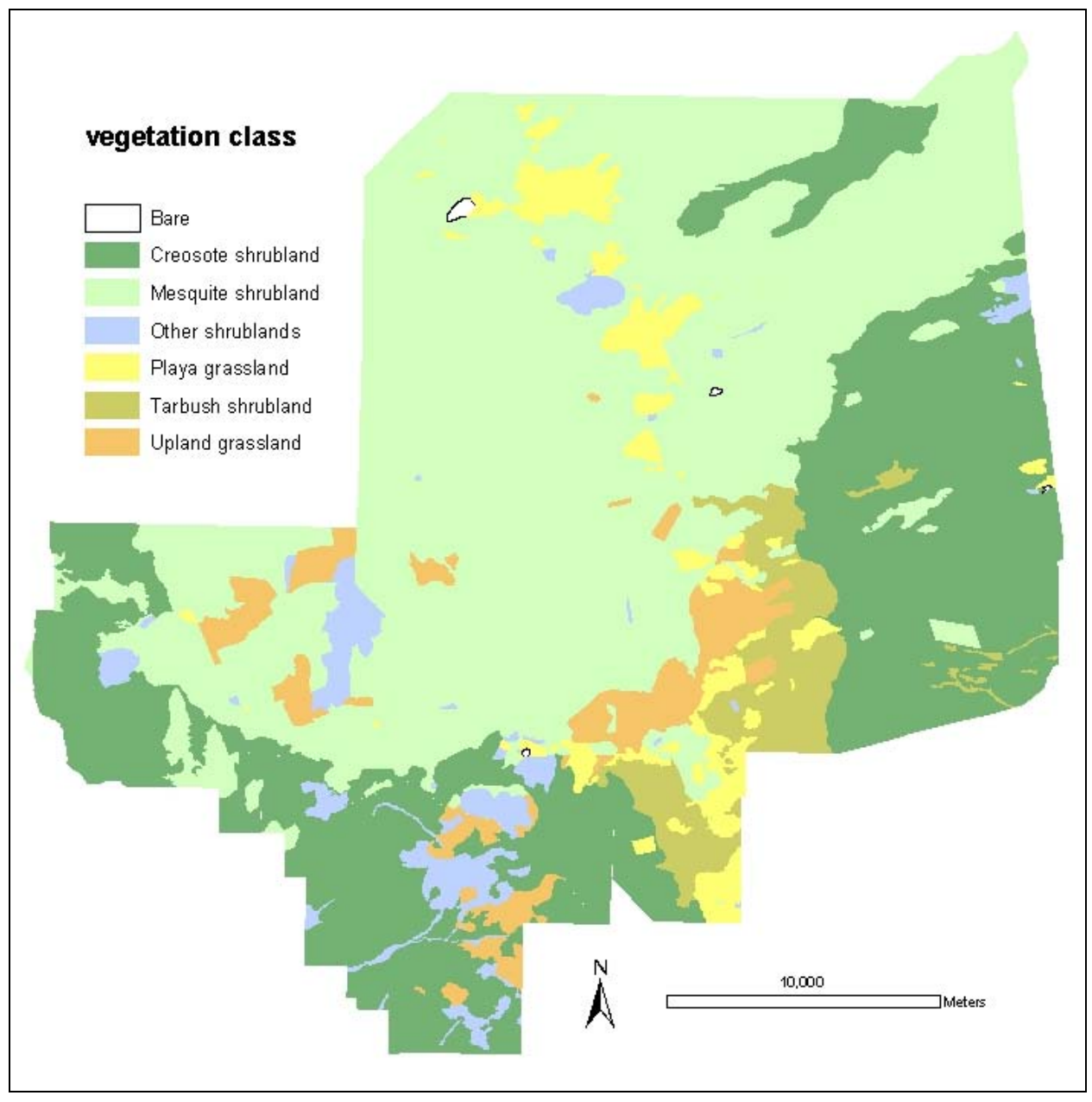

Figure 3. Major vegetation types of the Jornada Experimental Range and the Chihuahuan Desert Rangeland Research Center.

Chihuahuan Desert Rangeland Research Site operated by NMSU. We also found a more detailed map of soil types at the JER created in 1962. This soil map lists 20 soil types for the JER. Unfortunately, the description of these soil types does not contain details for soil texture needed for parametrization of ECOTONE.

Additional information on soil texture is available through our collaboration with the Jornada LTER program, where detailed soils studies were conducted along a transect running through a bajada (Wierenga et al. 1987). Furthermore, the Desert Project (Gile and Grossman 1997) has assembled a large amount of detailed soils information, and B. Bestelmeyer (JER-ARS) is working on correlating some of these data with vegetation data to develop a vegetation-soils map.

A long-term series of climate data is available from the USDA headquarters located in the middle of the Jornada Experimental Range (1915-present). We are 
using 80 years of these historical weather data for model parametrization (19181997). Because we were interested in the effect of drought on vegetation, we compared precipitation during the winter (October-May) and the growing season (June-September) for each year to the long-term average.

\section{Fort Bliss}

Data from Fort Bliss were assembled with the help of J.S. Fehmi, and they were stored on a CD. This CD contains data from previous experimental work as well as from work conducted for the parametrization and verification of the EDYS model. It is appended to the second report for the project between NMSU and CERL (Hochstrasser et al., in prep.). However, the data are of limited use since metadata are lacking and some data are in raw format, i.e. they would need to be transformed for comparison with other sites. Soils information on Fort Bliss can be obtained from the USDA-National Resource Conservation Service in El Paso, TX, which has completed a soil survey of Fort Bliss and published it on line in 2002 (http://soildatamart.nrcs.usda.gov/Survey.aspx?County=NM013).

Climate data were obtained from the National Climatic Data Center (http://www.ncdc.noaa.gov/oa/ncdc.html) for weather stations located near the military reservation [El Paso International Airport, TX (latitude: $31: 49^{\circ} \mathrm{N}$, longitude: $106: 23^{\circ} \mathrm{W}$, elevation: $1194.2 \mathrm{~m}$ asl); Dell City, TX (latitude: $31: 53^{\circ} \mathrm{N}$, longitude: $105: 14^{\circ} \mathrm{W}$, elevation: $1149.1 \mathrm{~m}$ asl); and Orogrande, NM (latitude: $32: 23^{\circ} \mathrm{N}$, longitude: $106: 05^{\circ} \mathrm{W}$, elevation: $1274.7 \mathrm{~m}$ asl)]. Daily minimum and maximum temperature as well as precipitation (as needed for model input) are available for E1 Paso Airport for 1948-2002, for Dell City for 1980-2002, and for Orogrande for 1996-2002.

\section{Description and comparison of sites}

\section{Jornada Experimental Range (JER)}

The Jornada Experimental Range is a 78,266-ha area operated as a ranch and research station by the USDA since 1912 . The site has been moderately grazed by domestic livestock. Over the past century, numerous management techniques for minimizing shrub encroachment have been tested at this site, and some practices are still continued (e.g. herbicide treatment of shrubs). Nevertheless, shrub dominance increased from $63 \%$ in 1918 to $92 \%$ in 1998 (R.P. Gibbens, unpublished data). The JER lies in an internal drainage basin, the Jornada del Muerto. Elevations range from 1,000 to 2,000 m asl, with desert grasslands and shrublands occurring between 1,300 and 1,650 m asl (Table 1, unpublished data by Jin Yao). The vegetation is representative of the northern Chihuahuan Desert. 
The climate of the Jornada is semi-arid with mainly summer monsoon rainfall. The mean annual precipitation is $248 \mathrm{~mm}(\mathrm{SD}=87)$, and the average monthly temperature ranges from $3.8^{\circ} \mathrm{C}$ in January to $26.1^{\circ} \mathrm{C}$ in July. Periods with no rainfall over 40 days occur on average about once or twice a year (Hochstrasser et al. 2002a). The analysis of the precipitation pattern for the winter (October-May) and the growing season (June-September) revealed the following patterns (Fig. 4): between 1950 and 1956 and between 1963 and 1968 both the growing season and winter precipitation were lower than the long-term average, which resulted in severe droughts at the Jornada during which significant mortality of plants was observed (Herbel et al. 1972). Between 1984 and 1987, precipitation was higher than the long-term average in both seasons. During a number of years the winter was wet but the summer was dry (using a 15\% threshold of the long-term average) $(1923,1931,1979,1980,1983,1992)$ (Fig. 4), whereas a number of years also had a wet summer following a dry winter (using a 30\% threshold of the long-term average) (1938, 1959, 1974, 1982, 1996).

Table 1. Elevational range of the five main vegetation types at the Jornada Experimental Range [Unpublished data from Jin Yao (08/13/03)].

\begin{tabular}{|l|c|c|c|c|}
\hline $\begin{array}{c}\text { Dominant } \\
\text { species }\end{array}$ & $\begin{array}{c}\text { Minimum } \\
\text { elevation }\end{array}$ & $\begin{array}{c}\text { Maximum } \\
\text { elevation }\end{array}$ & $\begin{array}{c}\text { Mean } \\
\text { elevation }\end{array}$ & $\begin{array}{c}\text { Number of 30- } \\
\text { x 30-m cells }\end{array}$ \\
\hline $\begin{array}{l}\text { Bouteloua } \\
\text { eriopoda }\end{array}$ & 1313.2 & 1634.8 & 1361.6 & 11,274 \\
\hline $\begin{array}{l}\text { Pleuraphis } \\
\text { mutica }\end{array}$ & 1308.2 & 1492.1 & 1330.5 & 5,143 \\
\hline $\begin{array}{l}\text { Larrea } \\
\text { tridentata }\end{array}$ & 1352.1 & 1530.5 & 1368.6 & 10,247 \\
\hline $\begin{array}{l}\text { Prosopis } \\
\text { glandulosa }\end{array}$ & 1319.8 & 1613.1 & 1349.0 & 12,285 \\
\hline $\begin{array}{l}\text { Flourensia } \\
\text { cernua }\end{array}$ & 1306.4 & 1490.2 & 1329.0 & 10,785 \\
\hline
\end{tabular}




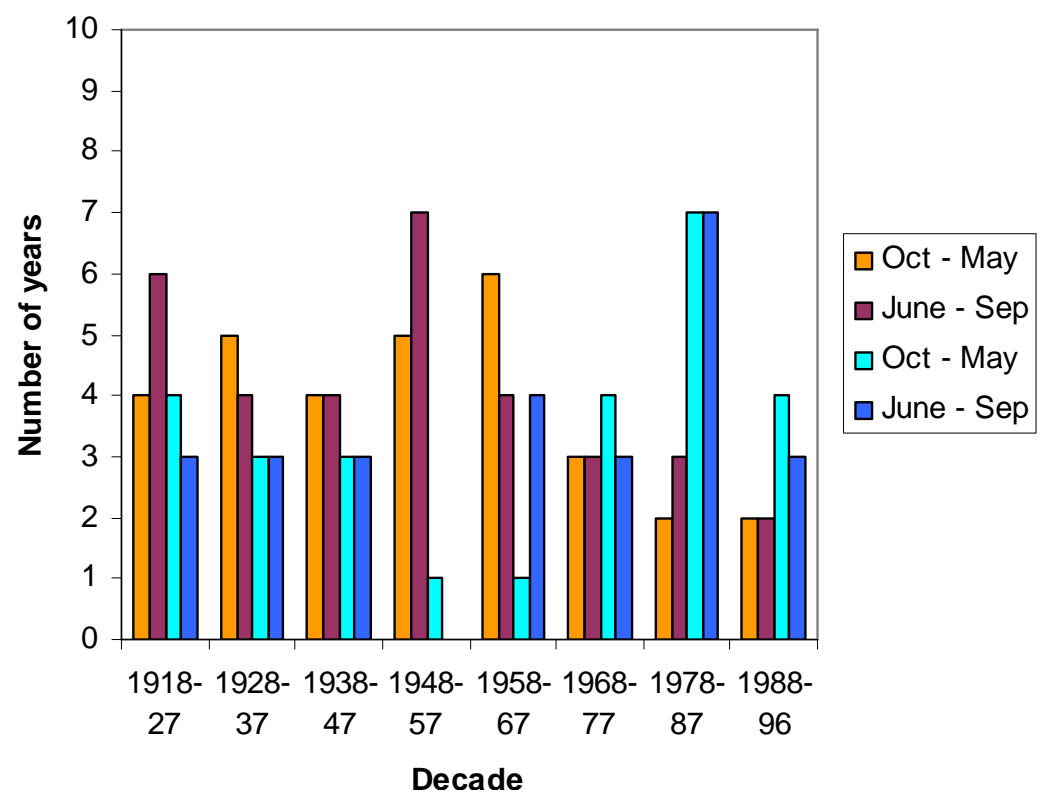

a. Years with $15 \%$ above/below average precipitation.

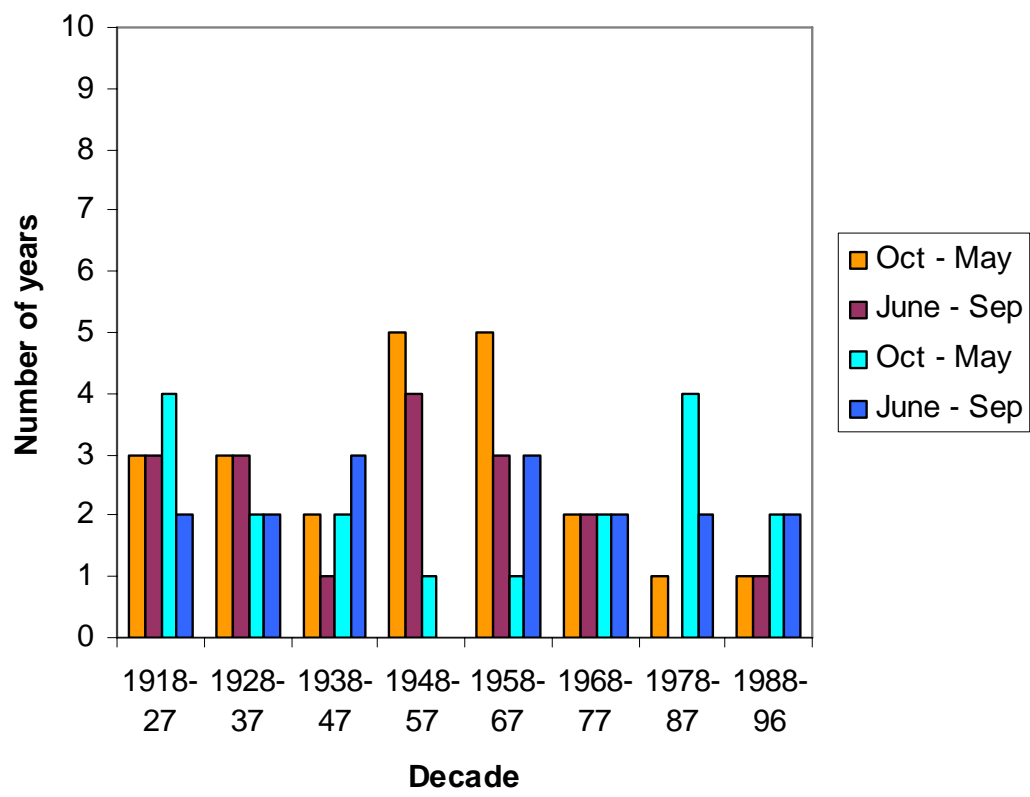

b. Years with $30 \%$ above/below average precipitation.

Figure 4. Comparison of the climate patterns in each season (winter: October-May, growing season: June-September) with the long-term average precipitation. The number of years that were above (blue) and below (red) the long-term average is depicted for each decade. 


\section{Fort Bliss}

Fort Bliss military reservation comprises an area of 445,154 ha in northwestern Texas and southern New Mexico. It has been operated by the military since 1889. The Bureau of Land Management is leasing parts of Fort Bliss for grazing. Military training occurs on the reservation. Fort Bliss includes many different habitats because of the size of the installation and the range of elevation $(1,164$ 2,692 $\mathrm{m}$ asl). This diversity includes Chihuahuan Desert shrublands and grasslands of several types and Rocky Mountain shrublands and montane forests (http://www.npwrc.usgs.gov/resource/othrdata/chekbird/r2/fortblis.htm). Seven major vegetation types have been distinguished: Pinyon juniper, Mesa grassland, Black grama grasslands, Whitethorn acacia, Creosotebush, Sandsage, and Mesquite (Pidgeon 2000). However, a GIS vegetation map from the installation shows only a gradation from lowland to upland vegetation (Fig. 5).

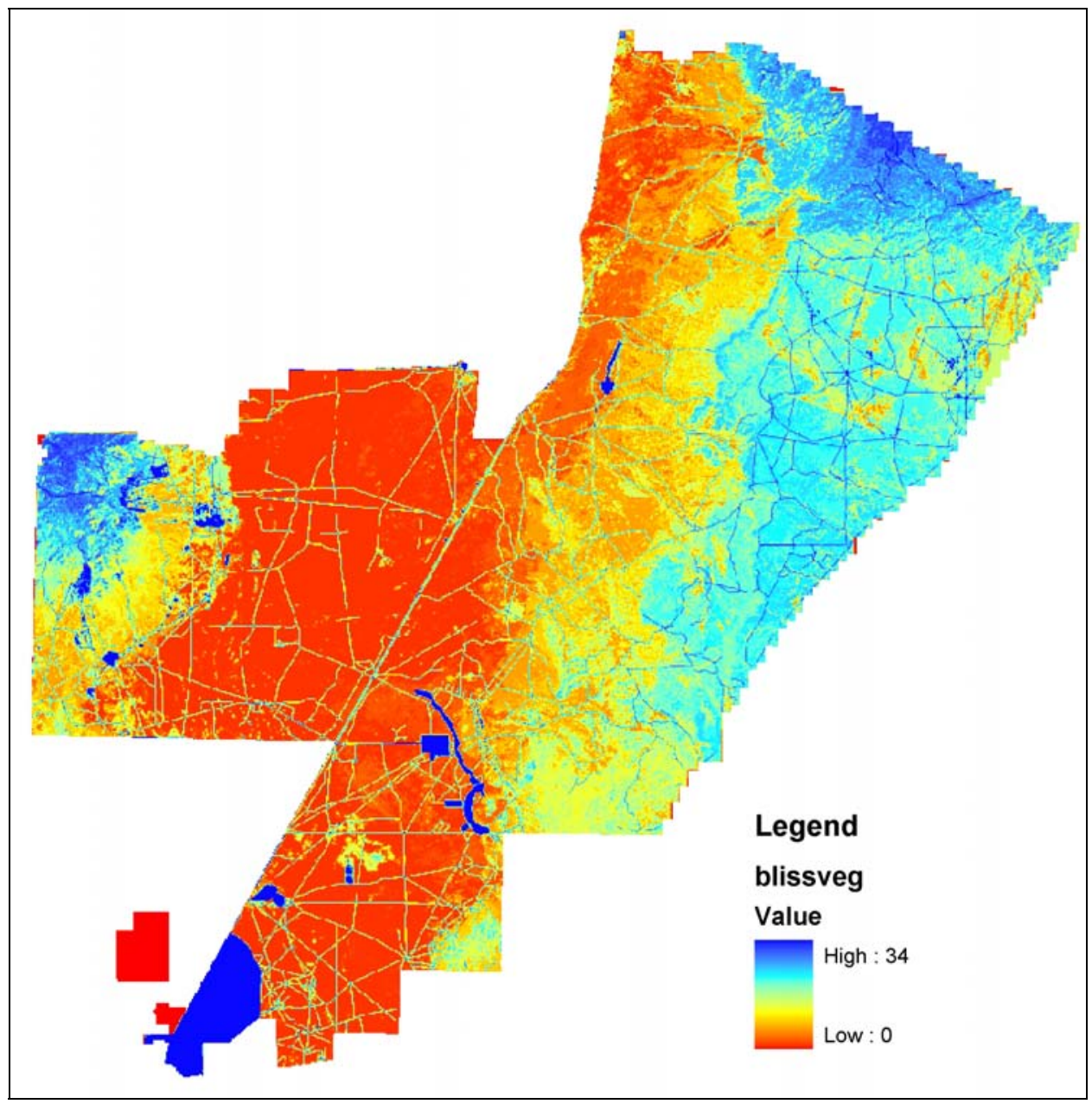

Figure 5. Vegetation map of Fort Bliss. 
Soils information on Fort Bliss is very detailed and up to date because the NRCS completed a new soil survey in 2002 (Fig. 6). The habitat diversity of Fort Bliss sustains a large number of plants and animals. Over 300 species of birds are found in the various habitats on Fort Bliss (http://www.npwrc.usgs.gov/resource/ othrdata/chekbird/r2/fortblis.htm). Notable mammals include the mountain lion, bobcat, ringtail cat, badger, bat, deer, and pronghorn antelope.

The climate of Fort Bliss is similar to the Jornada Experimental Range in that it receives predominantly summer rains (Fig. 7). The main difference between the Fort Bliss climate and the Jornada climate is that minimum temperatures are generally lower at the Jornada (Fig. 8). Variation in climate exists between different parts of Fort Bliss.

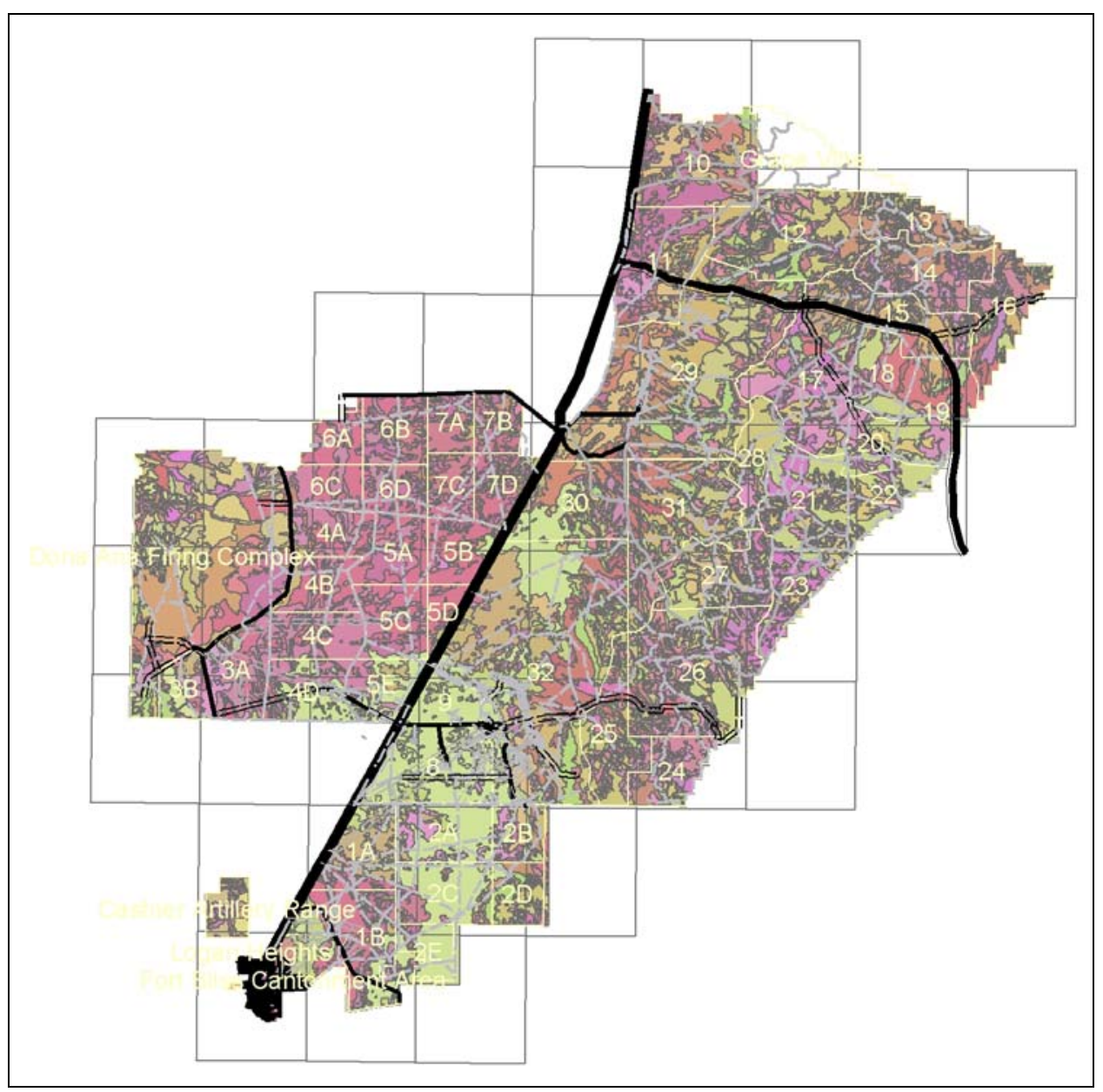

Figure 6. Soils map of Fort Bliss (USDA-NRCS 2002). 


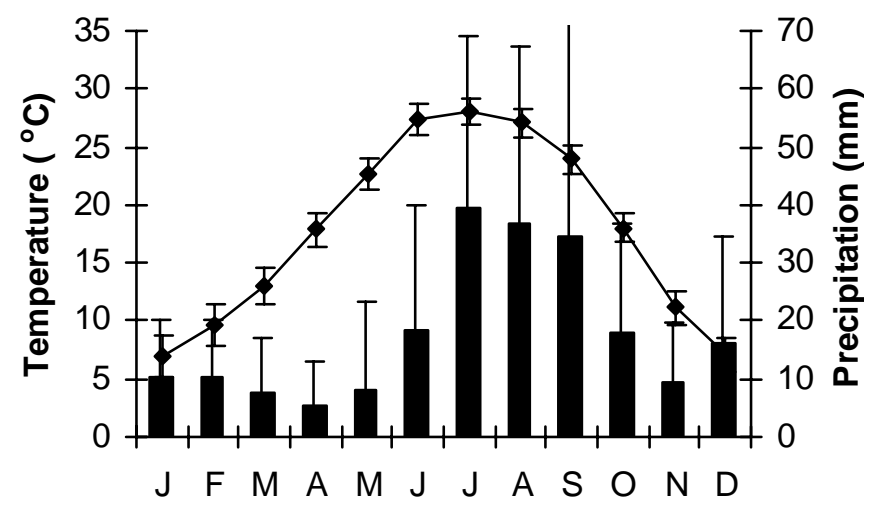

a. EI Paso International Airport.

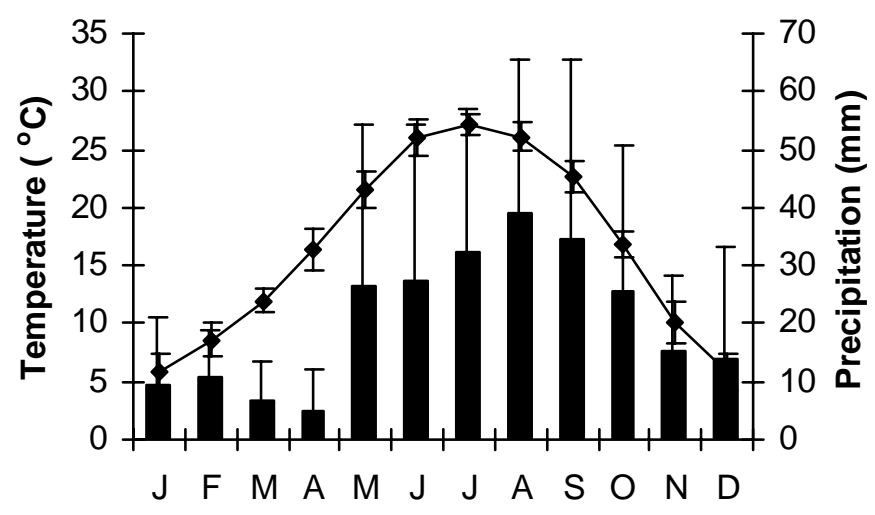

b. Dell City, TX.

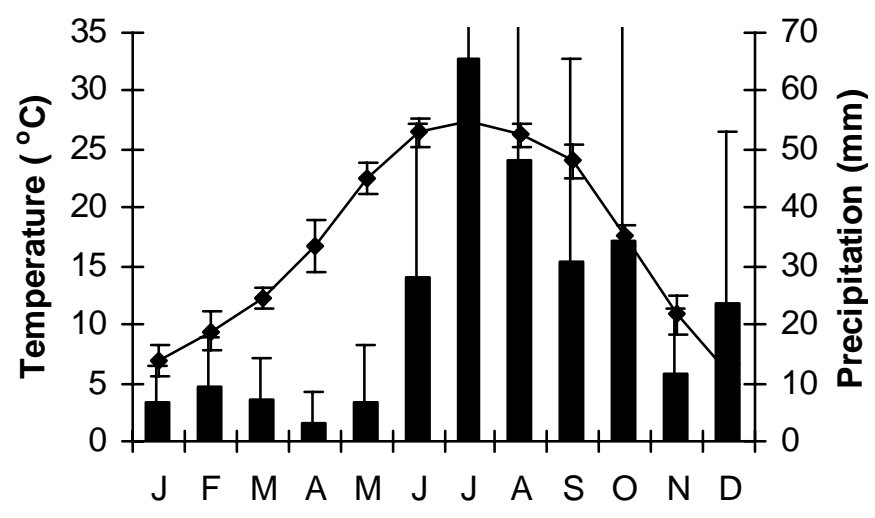

c. Orogrande, NM.

Figure 7. Climate data from weather stations near Fort Bliss. 


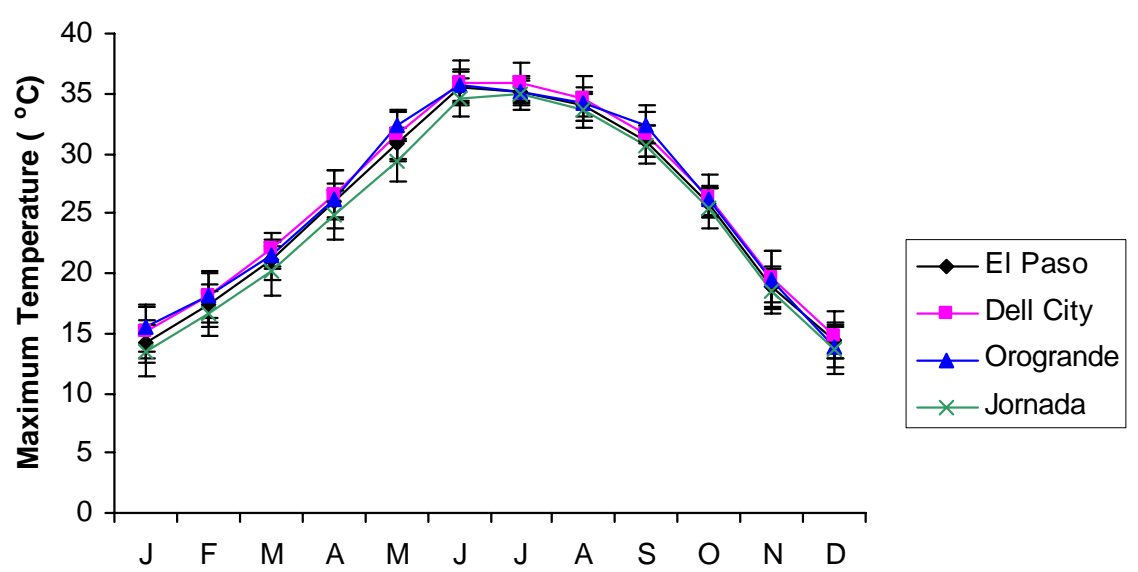

a. Mean monthly maximum temperature.

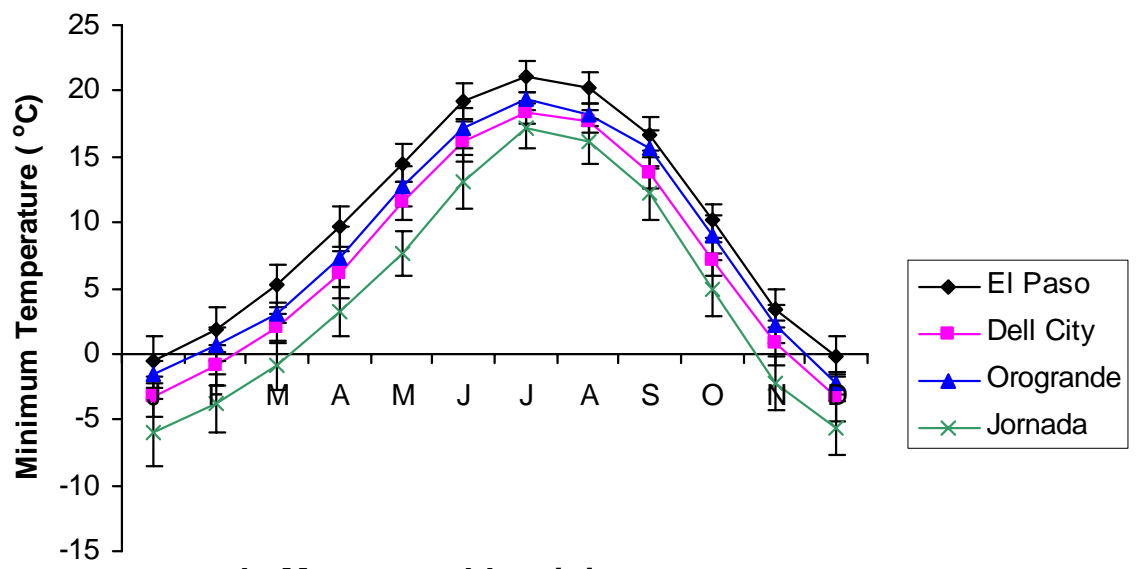

b. Mean monthly minimum temperature.

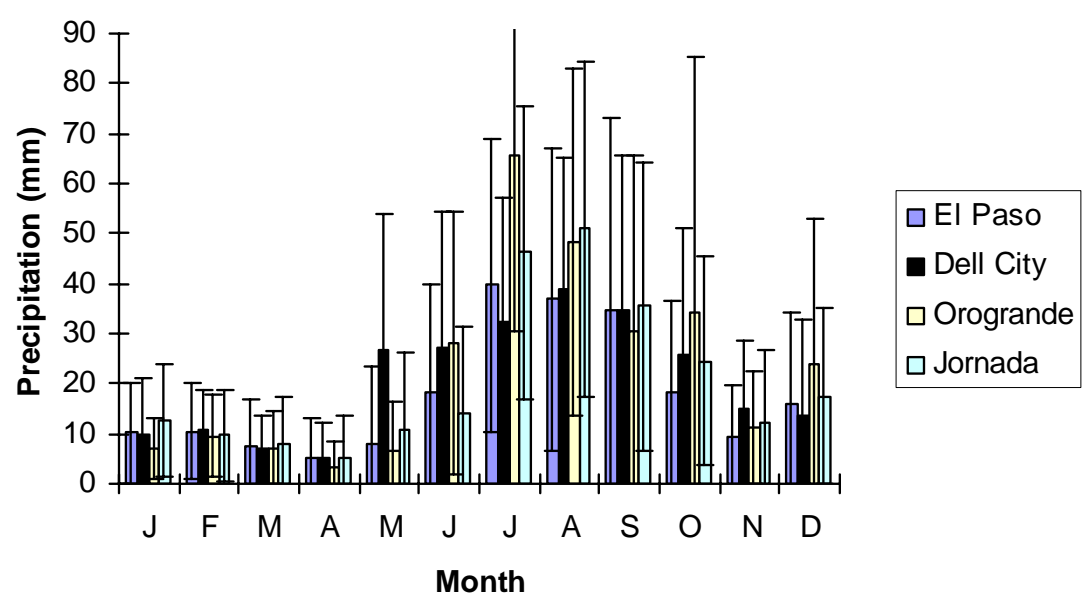

c. Mean monthly precipitation.

Figure 8. Comparison of weather data from Fort Bliss and the JES. 


\section{Conclusions}

Because of the lack of detailed information about Fort Bliss, it is difficult to compare the two sites. However, the climate is comparable between the two sites. More vegetation types are found at Fort Bliss than the Jornada, but prevalent vegetation types at the Jornada can also be found at Fort Bliss. 


\section{TASK 2. ECOLOGICAL CHARACTERISTICS OF DOMINANT SPECIES}

The second task was to conduct a search of existing data, peer-reviewed literature, and gray literature to determine available information on plants and soils identified in Task 1 and to assemble the results into tables for each plant species.

\section{Methods}

We searched online electronic databases available at New Mexico State University (NMSU) and through the USDA-ARS (AGRICOLA, BIOSIS, Current Contents) to compile a bibliography for the five dominant species at the JER; these species are also important at Fort Bliss. The bibliography was compiled in ProCite, a bibliography program that allows flexible formatting of references and that is commonly used by ecologists. Furthermore, the Jornada publications archive and the Jornada LTER bibliographic database were searched for references not found in the above resources. A total of approximately 800 references concerning the dominant species were identified. We also conducted interviews with a number of researchers who have experience with the ecology of these species (e.g., E. Fredrickson, R.P. Gibbens, L. Abbott, J. Anderson). Other sources of previous attempts to summarize ecological characteristics of species are also available. For example, we found extensive ecological information on a number of arid lands species at http://www.fs.fed.us/database/feis/.

Because the focus of this project was on species reactions to disturbances in arid lands, we used a previously completed bibliography (Fehmi et al. 2001) that contains general information on species reactions to disturbances (but not specific to the species of interest in this project). This information had to be adapted to the species of interest to be useable for this project. Recently, characteristics of plant species that contribute to their species-specific reaction to disturbance have been studied and identified (McIntyre et al. 1999; Weiher et al. 1999). Among these characteristics, we focused on those that are easy to measure. For some difficult to measure characteristics, we used correlated and easier-to-measure species attributes (Weiher et al. 1999).

For easy access to the references, we developed a hierarchical classification system of keywords to help researchers find information in the compiled bibliography (Appendix A). This resource has long been needed by ecologists in arid lands, since past attempts to assemble and gain an overview of ecological characteristics of these species have been limited by a lack of resources.

For the description of the relation of dominant species with soil characteristics, we relied on preliminary research results from B. Bestelmeyer (JER-ARS), 
who is studying vegetation-soil associations in southern New Mexico. In particular, he has gathered information on vegetation at sites where the soil was described by the Desert Project Soil Monograph (Gile and Grossman 1997). This preliminary information is the most comprehensive and best information currently available on vegetation-soil associations in southern New Mexico.

\section{Differences between grasses and shrubs}

Much has been written about ecological differences between woody plants and grasses (Belsky 1990; Wilson 1998; Peltzer and Köchy 2001). Often the difference in their ecological characteristics is further accentuated by their direct and indirect effects on the biotic and abiotic environment (Schlesinger et al. 1990; Wilson and Agnew 1992). One of the earliest works proposed that shrubs have access to deep soil water that grasses cannot access (Walker and Noy-Meir 1982). This hypothesis of vertical niche separation between the two lifeforms has been supported by experimental evidence (e.g. Jackson et al. 1996; Sala et al. 1997; Dodd et al. 1998). In environments where shallow water is common, woody plants have roots in both shallow and deep soil layers, and the niche separation between grasses and shrubs is not as clear (Wilson 1998). However, grasses and woody plants differ in other ecological characteristics, such as their root:shoot ratio, the amount of perennial tissue, their competitive effects on subdominant plants, their phenology, and their reaction and susceptibility to disturbances (Belsky 1994; Wilson 1998; Peltzer and Köchy 2001; Hochstrasser and Peters, submitted).

Because root competition is central to ECOTONE, we surveyed the literature on how root structure and function differ between grasses and shrubs. In particular, we were interested in how root distribution changes over time and how this change affects the competitive abilities of grasses and shrubs. A change in root distribution over time can be observed if there is root turnover (i.e. if old roots die and new roots grow in different places). Changes in root distribution over time therefore depend on factors that influence root growth and mortality. Root growth is a function of carbon supply, but environmental factors such as temperature and soil water distribution can be important (Luo et al. 1995). Root mortality is a function of the remaining above-ground biomass, temperature, and soil water (Luo et al. 1995). Generally, root turnover increases with temperature (with a Q10 relationship) (Gill and Jackson 2000). The phenological pattern of root growth also differs between grasses and woody plants: root production is high at the beginning of a growing season under aspen forest and declines over the growing season, whereas for mixed-grass prairie, root production increases until the peak of the growing season and then declines (Partel and Wilson 2002); roots in prairies seem to live about twice as long as in forests. Root turnover is $34 \%$ for total roots in shrublands, $53 \%(30-60 \%)$ for fine roots in grasslands, $50-250 \%$ 
for fine roots in forest (Gill and Jackson 2000), 20\% for fine roots in mixed-grass prairie, and $49 \%$ for fine roots in aspen forest (Partel and Wilson 2002). In blue grama, root turnover may range anywhere from $86 \% /$ year (according to production) to $35 \% / y e a r$ (according to mortality) (Gill et al. 2002). The longevity of roots depends on their diameter: the likelihood of mortality decreased approximately $6 \%$ with a $0.10-\mathrm{mm}$ increase in root diameter, controlling for the effect of depth in the soil profile (Gill et al. 2002).

The competitive ability of grasses and shrubs depends on root characteristics. In particular, differences in root surface area and rates of resource uptake are important determinants of competitive ability (Eissenstat and Caldwell 1988). Specific root length is ten times higher for grasses than for trees (Jackson et al. 1997), and total root length is twice as long in mixed-grass prairie than in aspen forest (Partel and Wilson 2002). Furthermore, the morphological and physiological plasticity in response to nutrient enrichment is an important characteristic of plants contributing to their competitive ability. Generally, the architecture of roots changes in nutrient-rich patches (herringbone structure) to increase root density (Fitter 1994). When comparing different lifeforms, it is important to consider that plasticity in biomass allocation and plasticity in root architecture are not necessarily related (Fitter 1994). Species with large rooting areas are less able to grow roots selectively in high-nutrient patches, suggesting a trade-off between the ability to explore large soil volumes and the ability to exploit nutrient-rich patches (Campbell et al. 1991). Spatial and temporal resource partitioning also influence competitive relationships between lifeforms.

\section{Species characteristics of the dominants}

Tobosa (Pleuraphis mutica) and tarbush (Flourensia cernua) occur on finertextured soil than the other species (creosotebush, mesquite and black grama) at the Jornada Experimental Range (Fig. 9). However, the distinction in terms of soil differences is not so clear (Fig. 9). Below we summarize the main ecological differences and similarities between the two dominant grasses, tobosa (Pleuraphis mutica) and black grama (Bouteloua eriopoda), and the two dominant shrubs, creosotebush (Larrea tridentata) and mesquite (Prosopis glandulosa). Tarbush (Flourensia cernua) was no included in this comparison because very little is know about the ecology of this species (Hochstrasser et al. 2002b).

\section{Comparison of black grama and tobosa}

Black grama and tobosa occur on very different soils: black grama tends to occur on upland sandy soils, while tobosa occurs in heavy clay soils, often in playas that receive run-in water (Fig. 9) (Neuenschwander et al. 1975; Wondzell et al. 1996). Black grama is relatively long lived (Wright and Van Dyne 1976; 


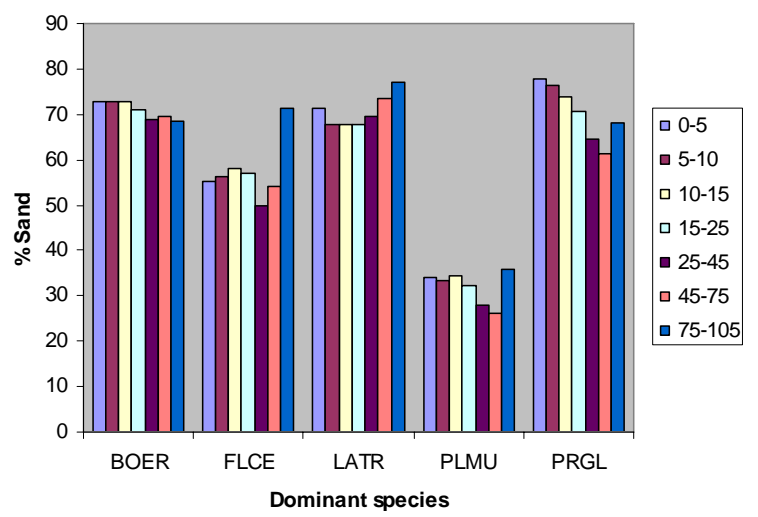

a. Percent sand.

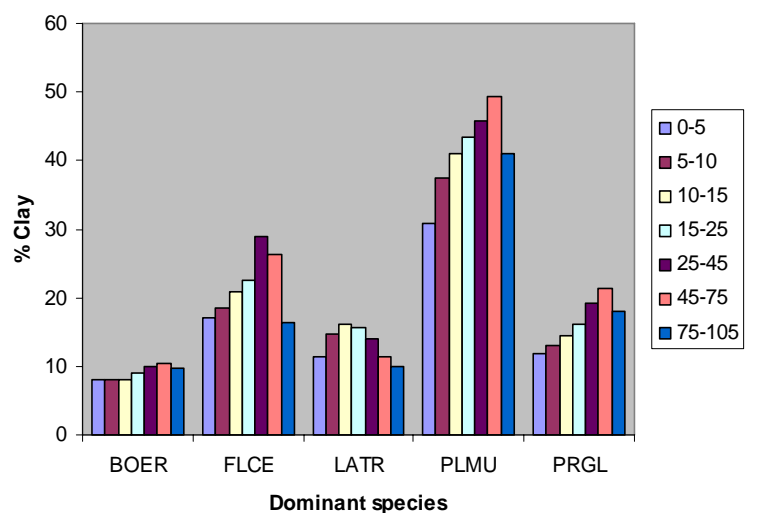

c. Percent clay.

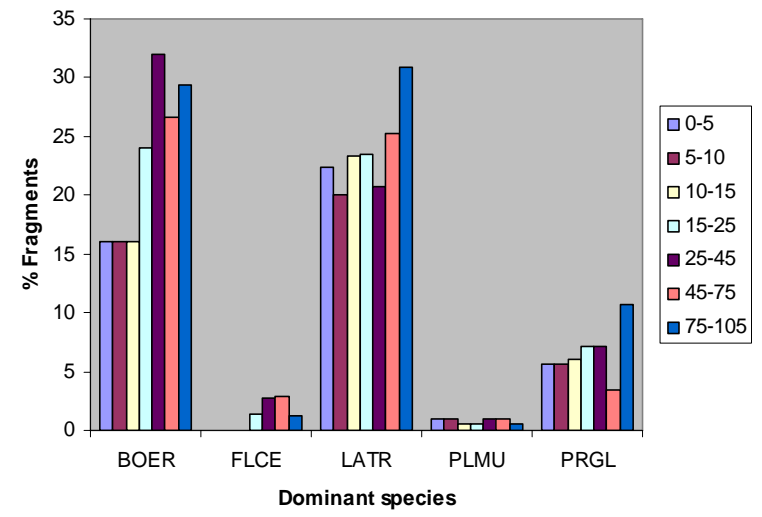

b. Percent fragments $>2 \mathrm{~mm}$.

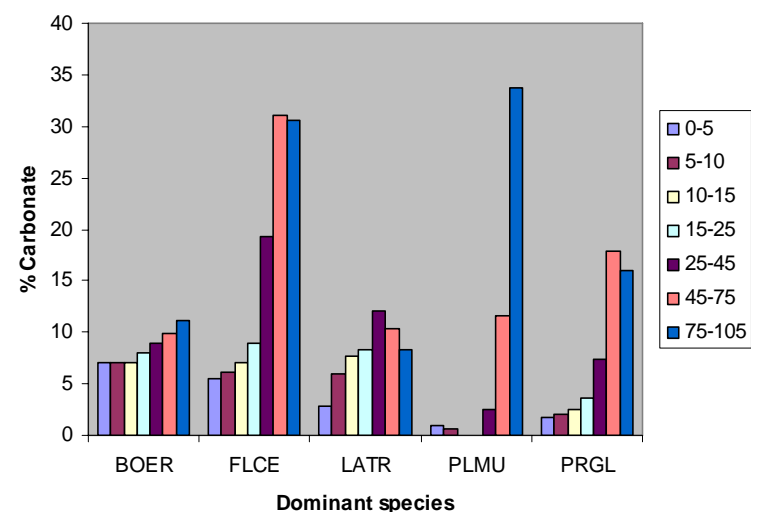

d. Percent carbonate.

Figure 9. Soil properties by depth of five vegetation types at the Jornada named after their dominant species: Bouteloua eriopoda (BOER), Flourensia cernua (FLCE), Larrea tridentata (LATR), Pleuraphis mutica (PLMU), and Prosopis glandulosa (PRGL). (Soils data from (Gile and Grossman 1997); vegetation data from B. Bestelmeyer (pers. comm.).

Canfield 1957), whereas tobosa is shorter lived (Wright and Van Dyne 1976). However, tobosa vegetation can be very persistent through time (Gibbens and Beck 1988). The roots of both species can spread over $1 \mathrm{~m}$ in depth (Gibbens and Lenz 2001). Both grasses have vigorous vegetative reproduction; black grama produces stolons, whereas tobosa produces rhizomes (Nelson 1934; Paulsen and Ares 1962). Reproduction from seed is limited in both species (Neuenschwander 1975; Neilson 1986). Black grama is more palatable to livestock than tobosa. The latter is only palatable during the growing season (Paulsen and Ares 1962).

\section{Comparison of mesquite and creosotebush}

Mesquite and creosotebush both expanded their range on the Jornada Experimental Range over the past 150 years (Buffington and Herbel 1965). They 
both occur on a wide range of different soil types. ${ }^{*}$ It is therefore difficult to link their distribution to differences in soil characteristics. Creosotebush is an evergreen shrub, whereas mesquite loses its leaves over the winter (NovemberMarch). Mesquite is a nitrogen fixer. Both species are long lived, although estimates of mesquite's lifespan [around 200 years (Archer et al. 1988)] are about half of creosotebush's lifespan [430 years (Miller and Huenneke 2000)].

Creosotebush seeds do not have any particular adaptation for seed dispersal, but can be transported by water and wind and in the fur of animals (Boyd and Brum 1983; Grover and Musick 1990). In contrast, mesquite pods are commonly consumed by livestock, and the germinability of the seeds is increased by scarification as they pass through the digestive system of animals (Brown and Archer 1989; Archer et al. 1988). In both species, establishment from seeds occurs infrequently. Both species can resprout after the above-ground biomass is removed. Both species have a wide root system that can reach to several meters deep (Gibbens and Lenz 2001). Creosote started growth within three days of a simulated rainfall, whereas mesquite did not green up (BassiriRad et al. 1999). A more detailed description of the ecological characteristics of each species can be found in Appendix B.

\footnotetext{
* Personal communication, B. Bestelmeyer.
} 


\section{TASK 3. CONCEPTUAL MODEL OF DISTURBANCES IN SHRUBLANDS VERSUS GRASSLANDS.}

The third task was to build a conceptual model and flow chart of plant and soil interactions and dynamics for each location using the information from Task 2.

Grasslands and shrublands differ by the kind and amount of feedbacks between soil resources and plants (Schlesinger et al. 1990; Wilson and Agnew 1992). In grasslands, plants are short lived, and therefore long-term storage occurs mostly in soil resources, whereas shrubs accumulate resources in their biomass (Fig. 10). In the absence of disturbance, grass morphology and function minimize resource loss from the soil, whereas the presence of shrubs leads to a redistribution and loss of soil resources (Schlesinger et al. 1990). Disturbance that impacts plants directly (e.g. trampling or off-road vehicle disturbance) accentuates the loss of resource from plants but not from the soil. Grasslands, where most of the resources are stored in the soil, are therefore likely to be less impacted by these disturbances than shrublands. However, if disturbances lead to erosional processes, they greatly affect grasslands and interrupt the regeneration cycle of grasses (Fig. 10). Furthermore, drought and grazing have a greater impact on grasses than on shrubs. Grazing selectively affects grasses, and drought often shortens their lifespan (Herbel et al. 1972). Therefore, to preserve grasslands it is very important to minimize erosion and disturbances that selectively affect grasses, such as grazing. For further conceptual models on how plants are affected by disturbances, see Hochstrasser et al., in prep.).

Grassland

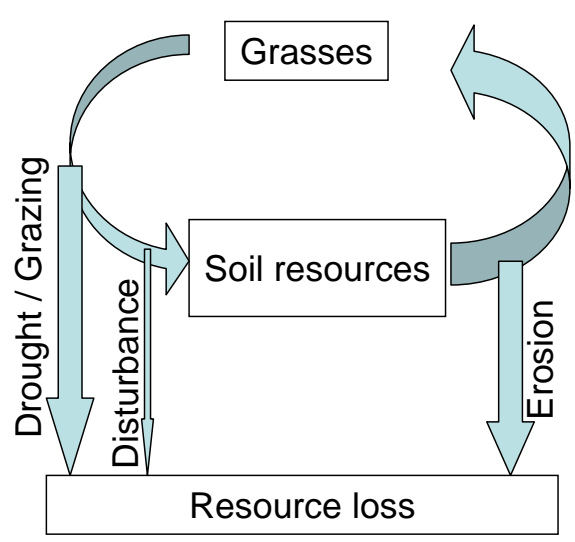

Shrubland

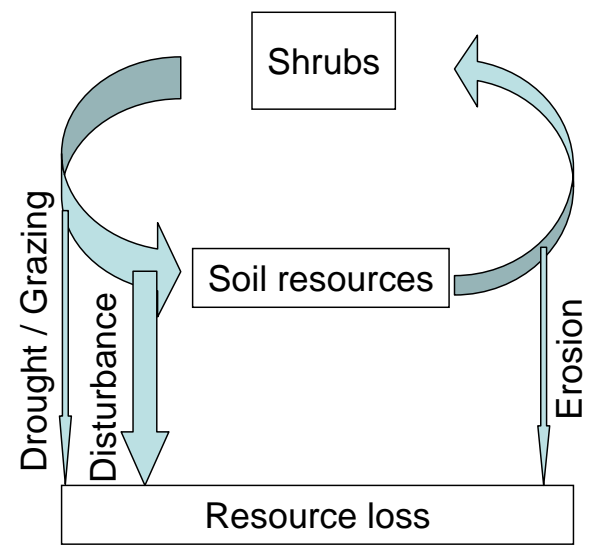

Figure 10. Conceptual model of disturbances in grasslands and shrublands. 


\section{TASK 4. SIMULATION MODEL USED: ECOTONE}

The fourth task was to develop and validate a simulation model to predict the most likely future plant communities using existing plants, high/low/average weather conditions, high/low/average/no military training, and soil slope and aspect for selected sites in Task 1.

An existing model (ECOTONE) was modified for this project (Peters 2002). ECOTONE is a gap-dynamics, individual-based model in that the recruitment, growth, and mortality of each plant in a given vegetation type are simulated explicitly based on life-history traits of the species or functional group; 10-20 species or functional groups are typically simulated in the model. A previous version of this model (STEPPE) was used to study the impact of small-scale disturbances in the shortgrass steppe (Coffin and Lauenroth 1988). More recently, ECOTONE has been used to predict changes in vegetation that may occur in New Mexico and Colorado with directional changes in climate (Peters 2002; Peters and Herrick 2002).

\section{Description of the model}

ECOTONE is a spatially interactive, individual-plant-based, gap-dynamics simulation model that simulates the recruitment, growth, and mortality of individual plants on a small plot (Peters 2002) (Fig. 11). Recruitment and mortality have stochastic elements, and growth is determined by competition for belowground resources (currently water). Plot size is determined by the resource space associated with a full-size individual of the dominant species, and it typically ranges from 0.5 to $2 \mathrm{~m}^{2}$ in desert grasslands and shrublands. ECOTONE can be run either with a spatially explicit connection between plots (dependent landscape, ltype $=2-$ runs.in) or with no spatially explicit connection between plots (independent landscape, ltype $=1$ - runs.in). If ECOTONE is run with a spatially explicit connection between plots, the seed availability in any given plot depends on seed dispersal to that plot. Input parameters include plant life history traits as well as environmental variables (daily precipitation and temperature, soil texture, and disturbance characteristics). A daily time-step soil-water model (SOILWAT) (Parton 1978) has been incorporated into ECOTONE to represent seasonal variation in plant growth as a result of daily temperature and water availability by depth in the soil profile. Growth and mortality of plants occurs on a yearly time step. Output includes species composition; plant density; above- and belowground biomass and production by species, size, and age distributions; and mortality statistics. In what follows we present details on the processes in ECOTONE as depicted in Figure 11. SOILWAT is described in Appendix C. 


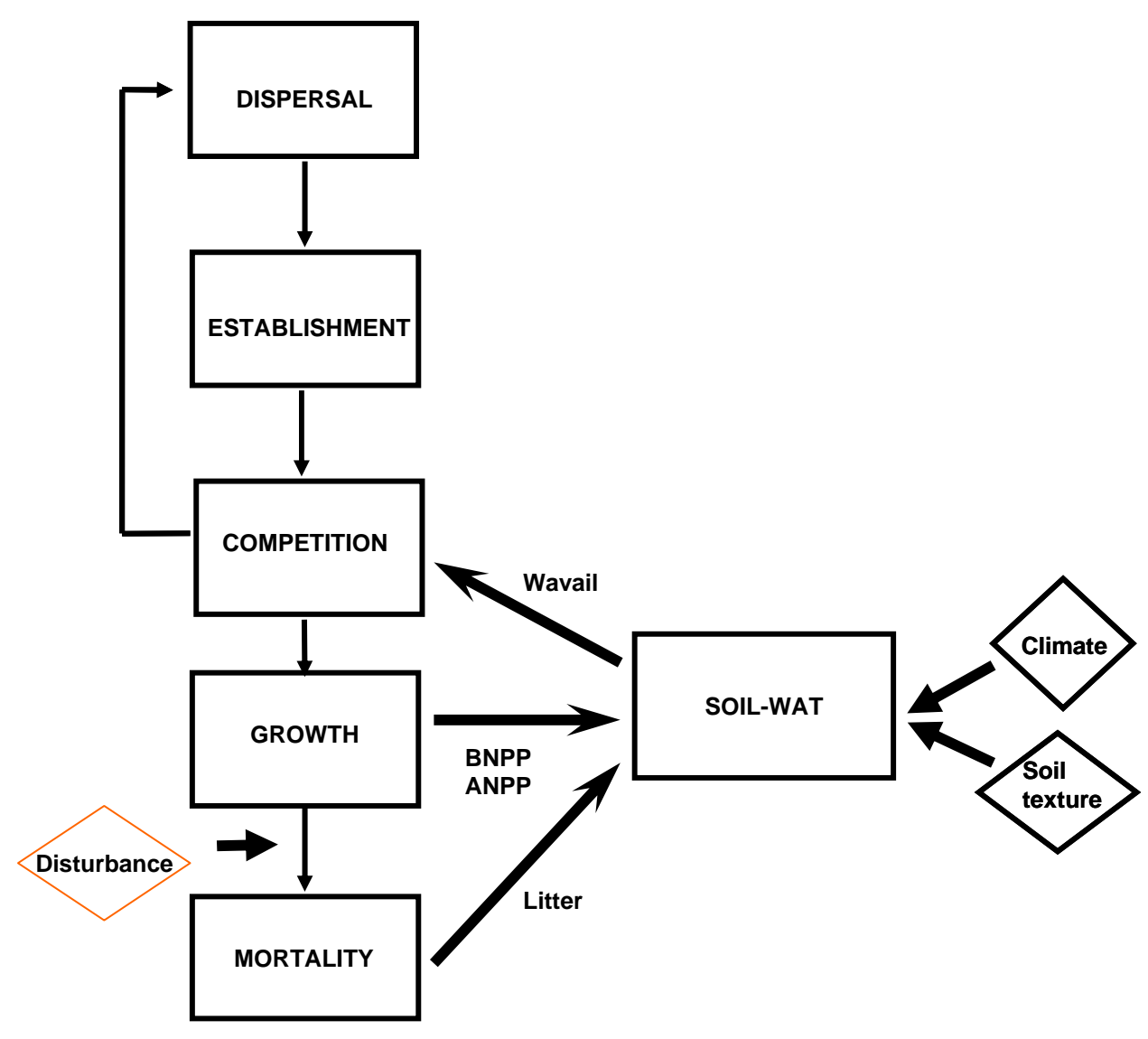

Figure 11. Flow diagram of ECOTONE.

\section{Dispersal}

The dispersal function used in ECOTONE was developed in 1989 (Coffin and Lauenroth 1989), mainly with a focus on grass seed dispersal. The dispersal function calculates the probability that a seed can reach a plot, given its distance from a plot with that species occurring on it, according to an exponential decay function. The user input is the maximum seed dispersal distance (SDDIST species.in). When calculating this distance, the user should take into account the release height and falling velocity of the seeds and the average wind speed at the study site (Peters 2002) After the probability of seed dispersal to a plot is calculated, it is stochastically determined if the seed reached the plot or not (i.e. seeds will either be available or not for recruitment in this year). If ECOTONE is run with a spatially independent landscape (ltype $=1-$ runs.in), the seed availability in the plot is 1 (i.e. seeds are always available). 


\section{Establishment}

Establishment in ECOTONE is determined stochastically. Each year, a number (between MINREC and MAXREC - species.in) of one-year-old plants can be recruited from a user-defined number of species (between mnrsp and mxrsp runs.in). The total number of recruits on each plot in each year cannot exceed a user-defined number (mxrec - runs.in). Each species has a probability of recruitment that depends on seed availability (see Dispersal) and a user-defined establishment probability (SDECOF - species.in). The probability of recruitment is normalized to 1.0 for all species eligible for establishment. Species are stochastically chosen for establishment according to their probabilities of establishment until the maximum number of species is drawn (or the maximum number of recruits has been reached, whichever comes first). Each plant recruited is given an initial biomass (corresponding to a one-year-old plant), which is determined as a percentage of the biomass of the full-grown plant [SDFRAT - species.in, the full-grown biomass being input by FULBIOA (above-ground biomass) and FULBIOB (below-ground biomass) - species.in].

\section{Competition}

Plant-available water in each soil layer (the soil layer structure of ECOTONE can be defined in soils.in) and each month is simulated using soils and weather data in SOILWAT (transpiration by layer by month). This information is then passed to ECOTONE, and plants compete in ECOTONE for this water. The proportion of water from each soil layer in each month that is distributed to each plant depends on its root surface area in that layer as well as its phenological activity. This proportion is computed based the current root biomass, the biomass-to-surface ratio (SAREAC for coarse roots, SAREAF for fine roots species.in), the fine-to-coarse root biomass ratio (as specified in speclyr.in), and the phenological activity of the plant. The latter is a scaling factor between 0 and 1 that is determined based on the optimal temperature for growth (TMPCOF2 species.in) and the average temperature of the month [equation 10 in Peters (2002)]. The relative amount of active root surface area in a given layer for each plant determines the proportion of the water the plant receives, i.e. the competition is symmetric to the active surface area of the roots.

\section{Growth}

The plant-available water that each plant receives is summed for the year and is the amount of water the plant can use to grow and maintain its biomass. The amount of biomass that can be grown given the water captured is determined by a biomass conversion factor (WUECNST - species.in). Before growth can occur, the perennial biomass of the plant has to be maintained. The amount of water 
required to maintain the perennial biomass of the plant corresponds to a fraction (MTNMODF - species.in) of how much water was needed to grow the biomass initially. If the water captured by the plant is less than the water required to maintain its perennial biomass, then clonal plants (CLONTYP $=1-$ species.in) can reduce in biomass, and other plants are tagged for slow growth. If there is more water available than the plant needs to maintain its tissue, then the plant grows. The new biomass is allocated to different plant compartments according to user-defined ratios: the root-to-shoot ratio (PRATIO - species.in) determines how much of the new growth is allocated above vs. below ground, the leaf-tostem ratio (PARATIO - species.in) determines how much biomass is allocated to annual vs. perennial tissue above ground, and the fine-root-to-coarse root ratio (speclyr.in) determines how much biomass is allocated to fine vs. coarse roots.

\section{Root distribution}

Before the new growth below ground is allocated to fine and coarse roots, the new biomass is distributed among layers according to relative amount of roots in each layer. The relative amount of roots per layer is calculated according to a user-defined, species-specific root distribution function at the beginning of each ECOTONE run. The user inputs for this function are the depth of maximum root biomass [RTDEPTH(1) - species.in] and the maximum rooting depth [RTDEPTH(2) - species.in] (Fig. 12). The root distribution is calculated accord-

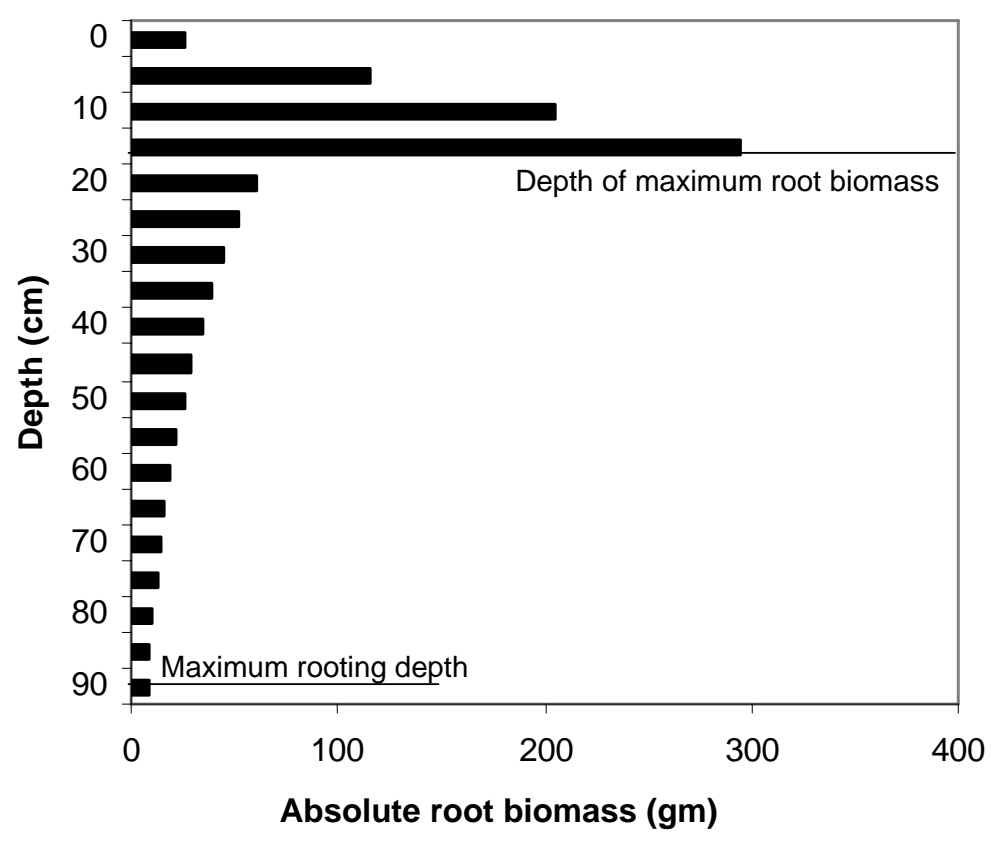

Figure 12. Root distribution of shallow-rooted grasses (Sun et al. 1997, Table 7). 
ing to a linear function from the soil surface to the depth of maximum root biomass and according to an allometric function from the depth of maximum root biomass [RTDEPTH(1)] to the maximum rooting depth [RTDEPTH(2)] (Sun et al. 1997) (Fig. 12). The user also inputs the relative amount of root biomass at the depth of maximum root biomass [BMAXD(1) - species.in] and the relative amount of root biomass at maximum rooting depth [BMAXD(2) - species.in].

\section{Mortality}

At the end of each year the entire annual and a certain percentage of the perennial biomass senesces. The percentage of perennial biomass that is lost is defined for each plant compartment: turnover percentage for coarse roots (CRTORATE - species.in), turnover rate for fine roots (FRTORATE species.in), turnover percentage of above-ground perennial biomass (LTORATE - species.in), and all of the annual above-ground biomass. The above-ground biomass lost from living plants is added to the litter.

Mortality of plants can have one of four sources: slow growth, size below minimum size, old age, and disturbance (Peters 2002). The mortality due to slow growth occurs after the plant has been growing less than expected [i.e. less than a certain percentage of its size (SLOINC - species.in)] for more than two years. Up to an age corresponding to half of the species' maximum lifespan (AGEMAX species.in), plants are exempt from mortality due to age. After this age the probability of mortality increases linearly until the maximum age is reached. If the probability is greater than zero, then it is stochastically determined if a plant dies of old age or not. The above-ground biomass of plants that died is added to the litter.

\section{Disturbance}

There are two kinds of disturbances currently in the model: natural and trampling. The natural disturbances occur stochastically at a user-defined frequency and have a user-defined size (disturbances.in). All plants are killed in natural disturbances, except if they can sprout. The probability of sprouting after disturbance is user defined (VEGGROW - species.in). If the plant sprouts after disturbance, then it regains $50 \%$ of its above-ground biomass and reduces its belowground biomass to $75 \%$ of its size before the disturbance occurred. The trampling disturbance routine is described in Appendix D.

\section{Feedback to SOILWAT}

Each year a number of plant parameters are passed to SOILWAT to calculate the plant-available water as a function of vegetation characteristics (Fig. 11). 
When plants have reached their maximum size for the year, the cumulative above-ground biomass (standardized for area) of all plants on a plot is passed to SOILWAT. After mortality and turnover, the amount of litter is recorded, and at the end of the year the root distribution in the plot is averaged between plants of the plot. The latter determines where in the soil the plants take up water.

\section{Model development}

The development of the model was done as a group effort involving the senior research scientist, the post-doc, and the programmer working on the model, as well as experts in fields researching different processes built into the model. We had regular meetings for this development.

Understanding the model structure and function is difficult and timeconsuming because of the large number of variables involved and multiple functions of these variables. Initially, the algorithms of ECOTONE had to be tested and the readability of the code had to be improved in order to make changes to the model. Once this work was completed, we developed a disturbance routine for trampling and vehicle disturbances. The initial testing of ECOTONE revealed that there were problems in the growth routine, the feedback between the vegetation and soil module of ECOTONE, and the root distribution routine. All of these problems were fixed for this project.

ECOTONE simulates a vegetation patch (i.e. a small grid of square plots that are the size of individual plants) by keeping track of all individual plants within this patch. This can involve handling and storing a large amount of data, and it imposes large demands on computation time. We therefore tested how long it would take to run ECOTONE with different spatial resolution for soil water availability. We found that the soil-water model (SOILWAT) coupled with ECOTONE was indeed the limiting factor in the speed of the simulation model because SOILWAT runs on a daily time step. In the current version of ECOTONE, we run SOILWAT only once for the entire patch per year and not for each individual plot in the vegetation patch simulated. Running SOILWAT once per plot and per year would have improved the correspondence of water availability with vegetation characteristics of the plot, but the costs in computation time did not warrant this change to the model.

\section{Mortality function}

We improved the mortality function to make it more compatible with the rest of the model. The function that determined the vulnerability of plants to mortality as they get older was based on a mortality function that included ALL sources of mortality (Shugart 1984). Since we have four sources of mortality (age, slow growth, smaller than minimum size, and disturbance) in the model, we changed 
the function to reflect increasing vulnerability to disease etc. with increasing age in the plants. We also rewrote some of the output routines to make output from the model more compatible with standard database formats.

\section{Disturbance routine}

We developed a trampling disturbance routine for ECOTONE (Appendix D).

\section{Sensitivity analyses}

We checked the sensitivity of the model to the amount of biomass present on the plots, the activity of the vegetation, and several other species characteristics. When checking the portioning between transpiration and evaporation, we found that the amount of transpiration increases with the amount of active biomass and litter in the model up to some maximum, after which it decreases because most of the precipitation is intercepted by the plant canopy and never reaches the soil (Fig. 13). Transpiration is a critical driver in model dynamics.

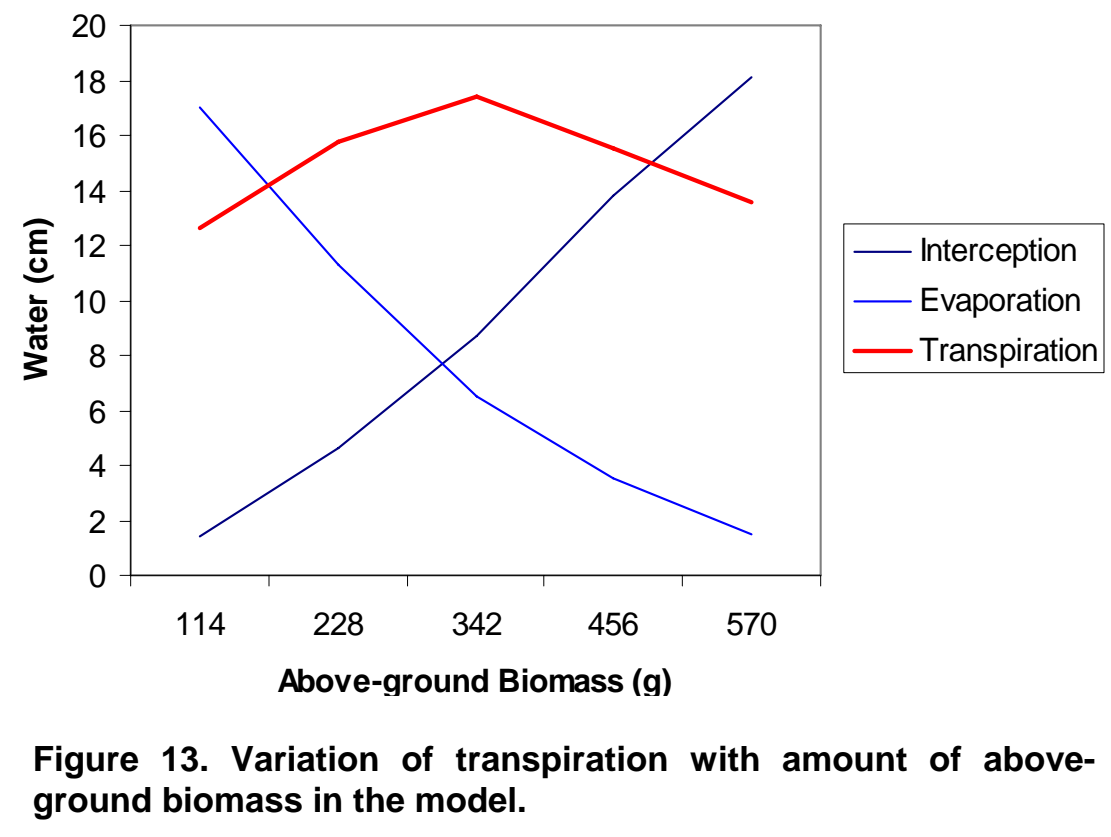

We also tested the temperature response curve in the model. This function drives the phenology of the plants in the model, which is crucial for plant growth. We found that the total amount of transpiration in a year is not sensitive to the phenology of the plant (i.e. its optimum temperature) (Fig. 14). However, the amount of transpiration in each month changes according to the optimum temperature for growth. 

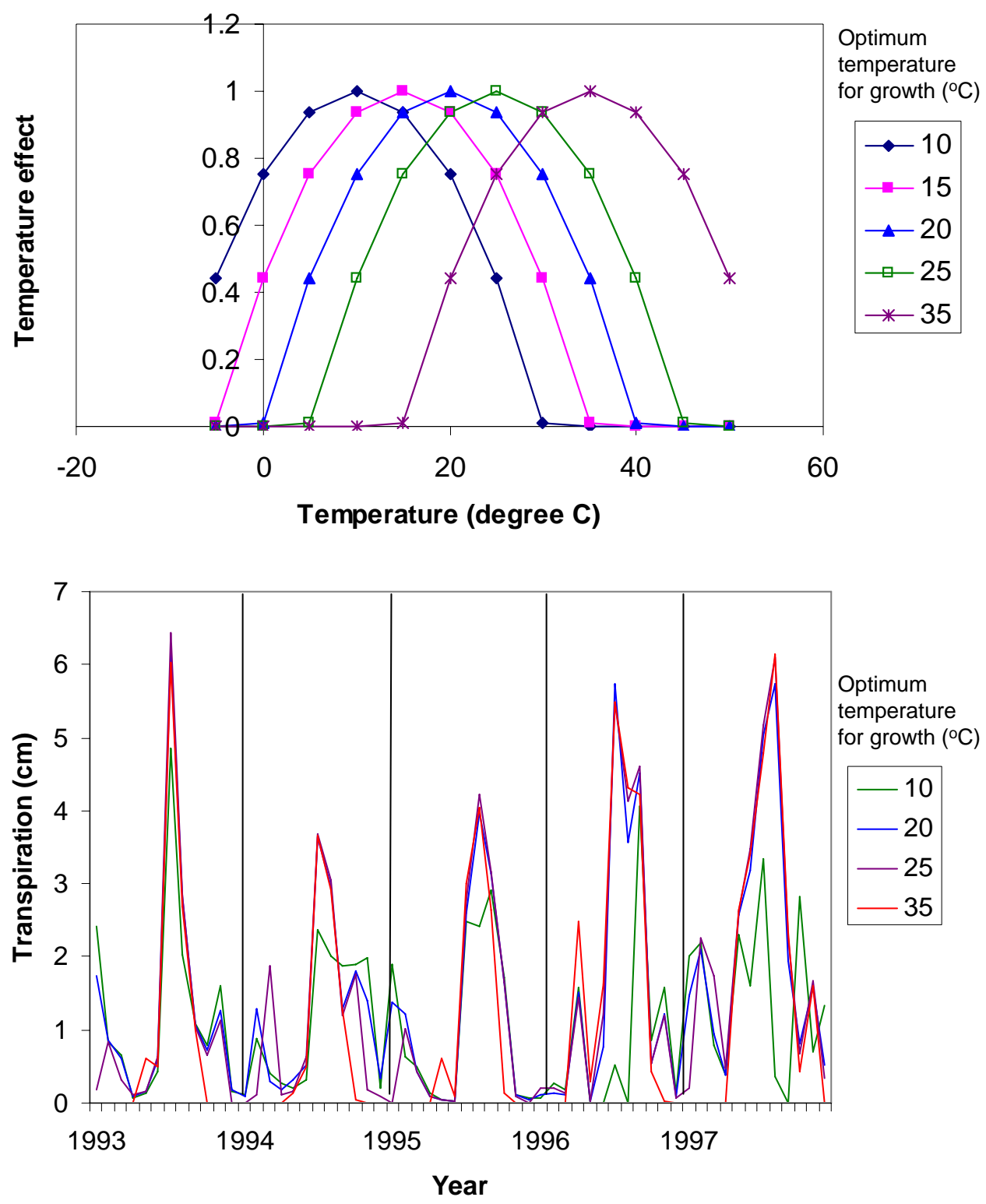

Figure 14. Temperature effect on plant activity and transpiration.

The sensitivity of the model to optimum temperature was compared to its sensitivity to other species characteristics. We found that the model was sensitive (in decreasing order) to the water-to-biomass conversion factor, optimum temperature, fine/coarse root proportion, and lifespan. The model was less sensitive to establishment probability and seed dispersal distance (results not shown). 


\section{Model parameters}

We extracted species characteristics from references in our literature review (Hochstrasser et al. 2002b). We also used existing reviews of species characteristics for information (http://www.fs.fed.us/database/feis/; Smith et al. 1997; Mabry et al. 1977; Simpson 1977). However, the published information was insufficient to fully parameterize the model, and we had to rely on expert knowledge to complete the parameterization.

\section{Analysis and Results}

We conducted a simulation experiment using ECOTONE to compare recovery time after human disturbance in desert grasslands and shrublands, both at the individual plant level and the population level.

\section{Parameterization of the model}

The model was parameterized for black grama grasslands and mesquite shrublands at the Jornada Experimental Range. Nine species and subdominant functional groups were simulated for each vegetation type. The soil was historically dominated by black grama (Bouteloua eriopoda) (Gill and Grossman 1997, Photo 1). Recent shrub encroachment has made mesquite (Prosopis glandulosa) the dominant vegetation. ${ }^{*}$ We compared the recovery dynamics of black grama grasslands versus mesquite shrublands for this selected soil.

Species parameters were derived from a literature survey of the dominant species (Hochstrasser et al. 2002b). For subdominant species, existing parameterizations of the model were used. Vegetation composition was matched with field records of the vegetation on the soil used in this model. Plot size was determined according to the resource space of a full-grown mesquite $\left(1.0 \mathrm{~m}^{2}\right)$ and black grama plant $\left(0.25 \mathrm{~m}^{2}\right)$.

Variation in the recovery time of vegetation following a disturbance can be caused by species differences relating to the amount of initial damage (resistance) and the amount of regrowth/recruitment after the disturbance (resilience).

Between lifeforms, the position of the perennating buds, the overall plant stature, and the leaf-stem architecture are important in explaining the resistance and resilience of the vegetation (Cole 1995). In general, grasses are both more resistant and more resilient to disturbance than other lifeforms (Yorks et al. 1997). Following these findings, we parameterized the model such that grass species were more resistant to disturbance (i.e. they had higher maximum pressure tolerance) than other lifeforms, shrub species were intermediate in resistance, and forbs were least resistant.

\footnotetext{
${ }^{*}$ Personal communication, B. Bestelmeyer.
} 
The model was driven by 80 years of daily weather data from the Jornada Experimental Range (1918-1997) in southern New Mexico, where black grama grasslands and mesquite shrublands are dominant vegetation types. Model simulations were for 200 years, during which the 80 -year sequence of historical weather was repeated.

\section{Simulation experiments}

Determining the recovery time of vegetation after a disturbance is difficult because of natural variation in the system. For experiments on trampling, it has been recommended that "recovery" be defined as the restoration of vegetation characteristics, not to pre-disturbance conditions, but rather to the current conditions of a control plot (Cole and Bayfield 1993). The comparison with the control plot takes into account the variation in vegetation due to climate and other factors not associated with the disturbance. We used this definition of recovery to evaluate our results.

Individual plant level. To determine disturbance effects on individual plants, we selected a dominant plant on a plot. We applied a one-time disturbance when this individual had reached an age corresponding to half its maximum lifespan. We repeated this experiment with a range of disturbance intensities, from a low-pressure impact (e.g. one passage of foot traffic) to a high-pressure impact greater than the plant's tolerance (e.g. one passage by a heavy vehicle). We measured the time it took the plant to reach the biomass represented in the nodisturbance control run. Recovery of black grama was compared to recovery of mesquite.

Plant population level. We indirectly simulated the effect of disturbance size on plant population recovery dynamics by simulating the effects of reduced seed availability on recruitment in large disturbances. Vegetation dynamics in a vegetation patch uniformly disturbed at high intensity (provoking plant mortality) were analyzed comparing unlimited seed availability (small disturbance) with a shortage of available seeds (large disturbance). The simulated vegetation patch was $5 \times 5 \mathrm{~m}$ in mesquite shrubland ( 25 plots $)$ and $2.5 \times 2.5 \mathrm{~m}$ (25 plots) in black grama grassland.

\section{Results: Recovery time in grasslands and shrublands}

Individual plant level. Significant differences were found between the recovery dynamics of a black grama grass and a mesquite shrub across a range of disturbance intensities (Fig. 15). Black grama grass recovered within a year from low-intensity disturbances and grew bigger than the control plant when the disturbance intensity was high. The latter result could be explained by the disturbance impact on competitors of black grama, which allows the already dominant 


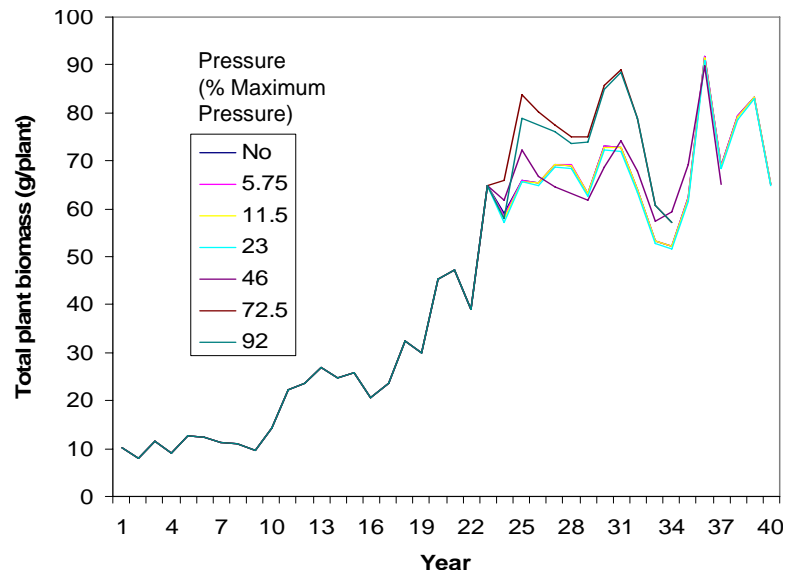

a. Total plant biomass over time for black grama.

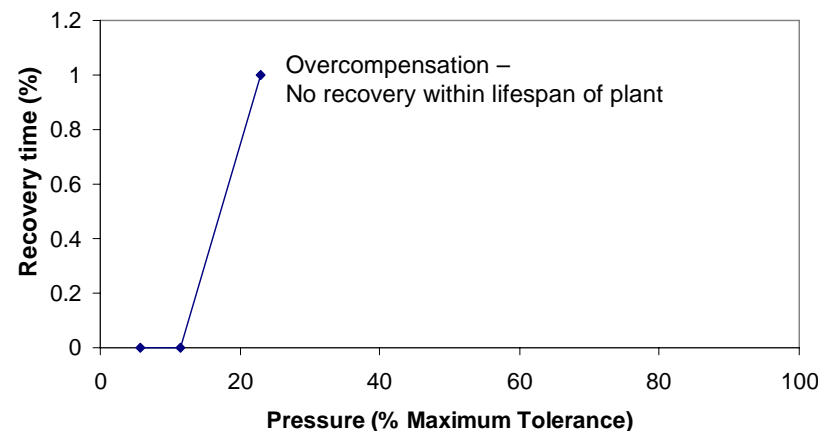

c. Recovery time for black grama.

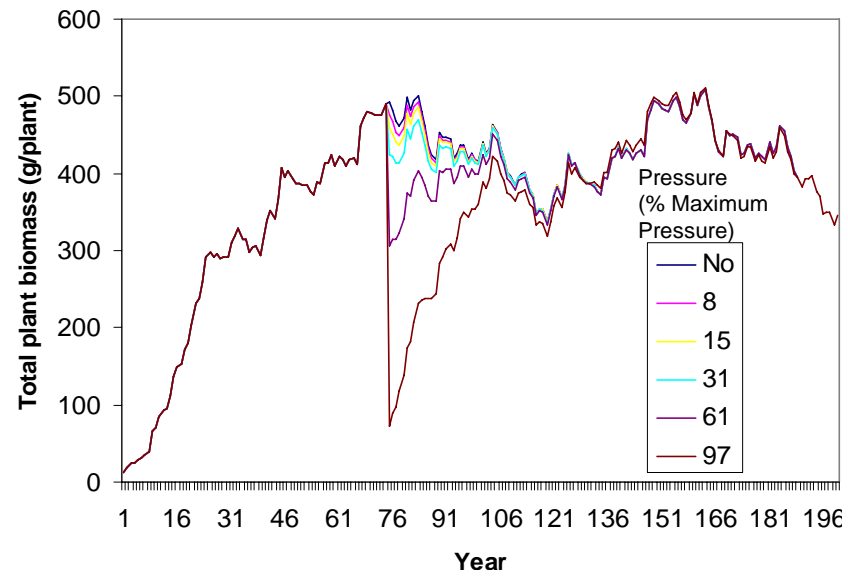

b. Total plant biomass over time for mesquite.

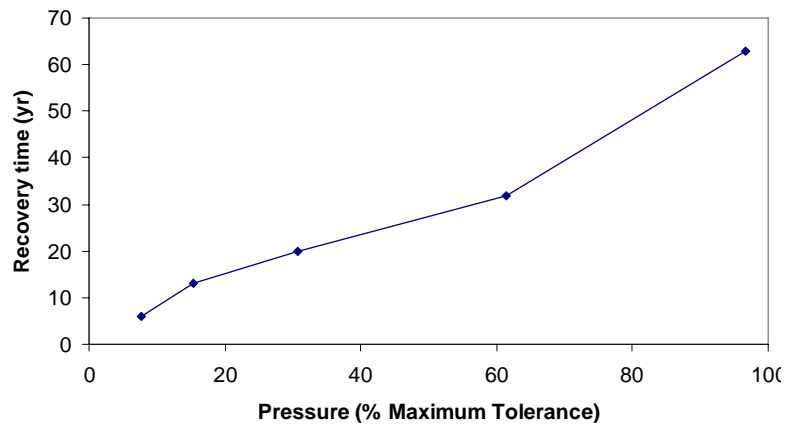

d. Recovery time for mesquite.

Figure 15. Model output: Recovery after a range of disturbance intensities of individual black grama and mesquite plants.

plant on the plot to capture more resources than were previously available. In contrast, the recovery time of a mesquite shrub increased with the disturbance intensity. At high intensities, the shrub took up to 60 years to recover from the disturbance. Differences in the recovery of these two species can be explained by the amount of biomass removed by the disturbance as well as their growth rate. Black grama loses less biomass during disturbance and has a higher growth rate than mesquite.

Plant population level. The black grama population was strongly reduced by the disturbance that killed all plants in the simulated grassland patch. After the disturbance, the black grama population took an average of 20 years to recover (Fig. 16a, b). In contrast, the mesquite population in the simulated shrubland patch took longer to recover to the control level (on average about 50 years). In the control simulation, mesquite biomass started to decline after year 150 as the 


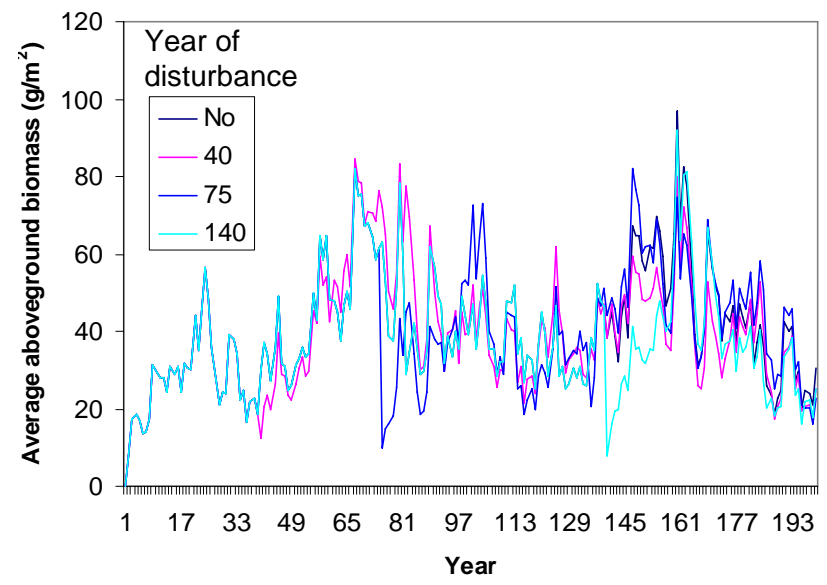

a. Black grama, unlimited dispersal.

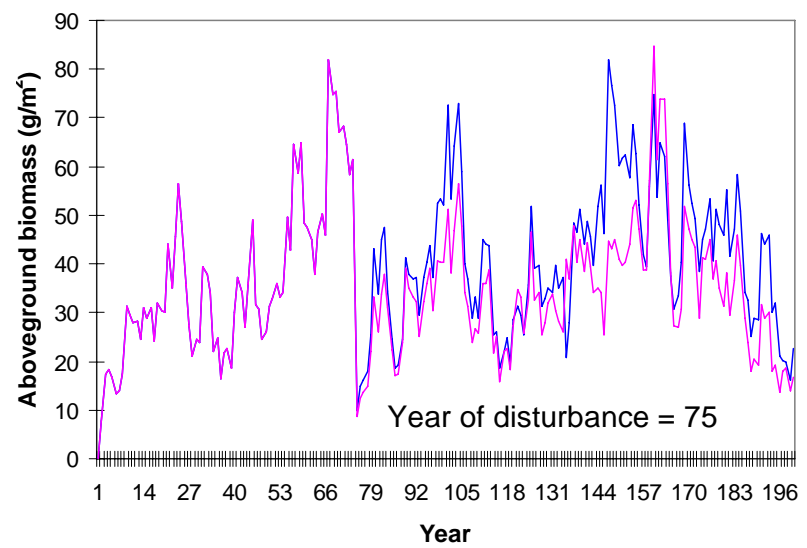

No limitation _- Dispersal limited

c. Black grama, limited dispersal

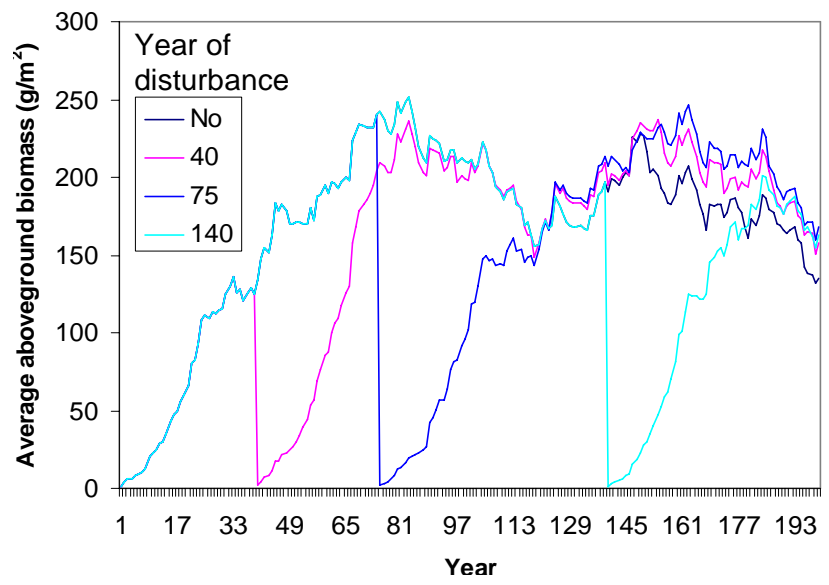

b. Mesquite, unlimited dispersal.

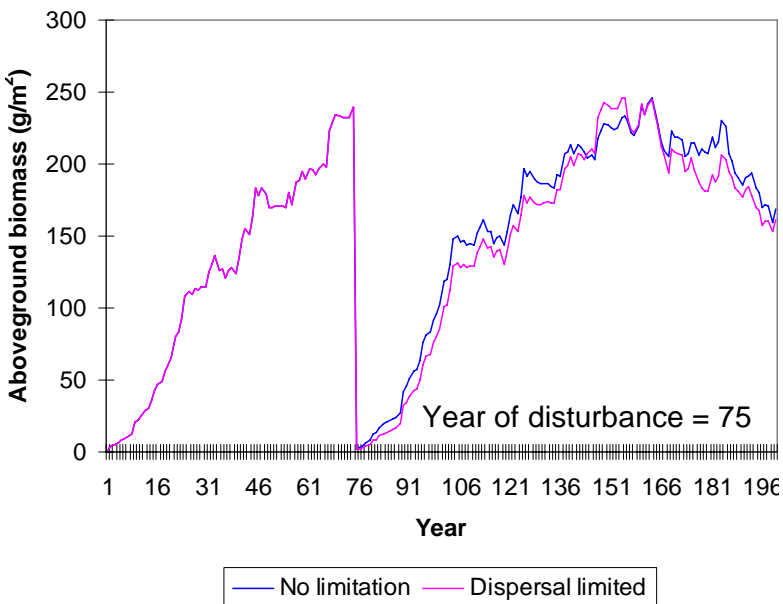

d. Mesquite, limited dispersal.

Figure 16. Recovery after a disturbance of high intensity (causing plant mortality) at the population level. Unlimited dispersal would occur at a small disturbance; limited dispersal would occur at a large disturbance.

population reached its maximum lifespan of 200 years. In contrast, the individuals in the disturbed populations were younger and maintained a high level of biomass at the end of the simulation run.

Dispersal limitation after the disturbance, as may occur in large disturbance patches, impacted the recovery dynamics of both dominants (Fig. 16b, c): the black grama population still recovered relatively rapidly but could not attain the average biomass of the plot without the dispersal limitation. This result indicates that black grama populations depend on relatively high recruitment rates to maintain 
their population size. In contrast, recovery in the mesquite population was slower than in a non-dispersal-limited situation, but the population could still attain and even surpass the average biomass that it maintained without the disturbance.

\section{Discussion}

These ECOTONE simulations allowed us to capture important differences in species characteristics between grasses and shrubs and to test how these two lifeforms react to disturbances of varying intensities and size. Our results correspond to previous experiments investigating the effects of trampling on different lifeforms (Cole 1995, Yorks et al. 1997, Herrick and Belnap 2002) but contradict long-term observations. Apart from the biological differences between shrubs and grasses as simulated in this work, the spatial distribution of anthropogenic disturbances may not uniformly impact all plants (as assumed in this model). In particular, mesquite shrubs are commonly avoided both by foot and vehicle traffic, which may explain why shrubs are usually found in disturbed situations despite their low resistance and resilience.

The estimates of recovery time observed in this research should only be considered guidelines as to the relative differences between grasses and shrubs in arid environments. Because long-term experiments are lacking, it is impossible to verify if the modeled estimates are accurate. Recovery times of vegetation also depend on the timing of the disturbance in connection with the phenology of the plant. ECOTONE currently simulates vegetation growth and mortality on a yearly timestep, such that seasonal dynamics could not be taken into consideration.

Disturbances in arid lands can also lead to soil compaction that depends on soil type and soil moisture content at the time of disturbance. Soil compaction leads to a decrease in infiltration and a decrease in plant-available water. Surface compaction can also inhibit germination and establishment of plants. These factors may alter vegetation dynamics after disturbance and shift species composition. Additional processes not simulated in the model may also change recovery dynamics. For example, a reduction of vegetative cover can lead to wind erosion.

\section{Conclusions}

Grasses recover more rapidly from disturbance than shrubs because of their high resistance and resilience, both at the individual plant level and the population level. Despite the high resistance and resilience of grass plants, they are more vulnerable to disturbance than shrubs because of their dependence on recruitment for maintaining their population size. Additional processes, such as the effects of wind erosion and human behavior, may further enhance the advantages of shrubs for surviving trampling and vehicle disturbances. 


\section{SUMMARY AND RECOMMENDATIONS}

In this work, we summarized the ecological characteristics of dominant shrubs and grasses at the Jornada Experimental Range. This information is relevant to Fort Bliss since these vegetation types can also be found there. We used the fundamental ecological differences between shrubs and grasses to test for differing reactions to disturbances. First, we developed a conceptual model of these differences. We also incorporated the insights from our shrub-grass comparisons into the simulation model ECOTONE in order to estimate recovery times from disturbances of different intensities and sizes. The results obtained from the simulation model indicate that this model is capable of capturing the main differences between grasses and shrubs. However, future work should focus on incorporating landscape-scale effects of disturbances and indirect processes.

\section{Research needs and recommendations}

The simulation model we used for this project has the plant-water relationships incorporated into it, but it lacks processes related to plant nutrient uptake. These processes may be important in arid lands, especially during times when water is available. More research on the disturbance effects on nutrient availability is needed.

Soil erosion by wind and water is often an important consequence of disturbances in arid lands. The redistribution and/or loss of resources for plants due to erosion can influence plant-plant interactions and future vegetation dynamics. Because of the strong effects of these processes on community composition, we recommend incorporating these effects into ECOTONE.

The damage caused by applying pressure to vegetation is not well understood, partly because it is difficult to determine how much pressure has been applied to any given spot in the vegetation, partly because the damage to the vegetation has not been well studied. Even though for agricultural vehicles the pressure distribution under the wheels has been extensively studied, less is known about the pressure under the tracks or wheels of military vehicles. Furthermore, it would be helpful to know how the pressure varies with the driving speed and style of the driver.

An alternative to learning more about the damage resulting from military vehicles at the plant scale may be to integrate processes at a higher organizational level (e.g. a patch, a landscape) and search for more simple relationships between the amount of training and damage to the vegetation. This will not foster a mechanistic understanding, but it can help to evaluate the amount of disturbance that can be supported by a certain type of vegetation. 
In this work we incorporated a study of the ecological characteristics of the dominant species. However, to fully understand vegetation dynamics after disturbances, it is important to incorporate subdominant plants into the study. This poses a particular challenge because less is known about the ecological characteristics of these plants than about dominants. Therefore, further studies on subdominant plants and their reactions to disturbances are needed. This can be particularly crucial when invasive species are present in the area and pose a threat to native communities.

\section{Management implications}

Even though shrubs are vulnerable to above-ground disturbances, such as those caused by military training, they are more resistant to erosional processes than grasses. Therefore, it is very important to prevent wind erosion whenever possible. This can be done by choosing areas that are less vulnerable to wind erosion (because of either their soil characteristics or their high vegetation cover) for military training (Gillette and Adams 1983). In contrast, grasses are more resistant to disturbances, but because of their high turnover rates and their dependence on soil resources, they are difficult to restore once the grass cover is lost. Therefore, it is best to avoid the combination of grazing with military disturbance. When grass cover is healthy, grasses likely can outcompete shrub seedlings (Brown and Archer 1989).

Plants also differ in their vulnerability to disturbance according to their size. In particular, shrub seedlings are more vulnerable to disturbances than adult shrubs, which suggests that if shrubs get established, it is important to remove the seedlings as soon as possible, while they are still susceptible to control measures. Once established, shrubs contribute to resource redistribution and loss and often make grass establishment impossible (Wilson and Agnew 1992). We recommend any measures that can keep the lifeform composition such that grasses are prevalent. The structural changes in the ecosystem with a shift in the dominant lifeform from grasses to shrub affect many ecosystem processes, including the resistance of the vegetation to future disturbance. 


\section{REFERENCES}

Archer, S., T.W. Boutton, and K.A. Hibbard (2001) Trees in grasslands: Biogeochemical consequences of woody plant expansion. In Global Biogeochemical Cycles in the Climate System (E.-D. Schulze, M. Heimann, S. Harrison, E. Holland, J. Lloyd, I. Prentice, and D. Schimel, ed.). San Diego: Academic Press, p. $115-138$.

Archer, S., C. Scifres, C.R. Bassham, and R. Maggio (1988) Autogenic succession in a subtropical savanna: Conversion of grassland to thorn woodland. Ecological Monographs, 58(2): 111-127.

BassiriRad, H., D.C. Tremmel, R.A. Virginia, J.F. Reynolds, A.G. de Soyza, and M.H. Brunell (1999) Short-term patterns in water and nitrogen acquisition by two desert shrubs following a simulated summer rain. Plant Ecology, 145: 2736.

Belsky, A.J. (1990) Tree/grass ratios in East African savannas: A comparison of existing models. Journal of Biogeography, 17: 483-489.

Belsky, A.J. (1994) Influences of trees on savanna productivity: Tests of shade, nutrients, and tree-grass competition. Ecology, 75: 922-932.

Boyd, R.S., and G.D. Brum (1983) Postdispersal reproductive biology of a Mojave desert population of Larrea tridentata (Zygophyllaceae). American Midland Naturalist, 110(1): 25-36.

Brown, J.R., and S. Archer (1989) Woody plant invasion of grasslands: Establishment of honey mesquite (Prosopis glandulosa var. glandulosa) on sites differing in herbaceous biomass and grazing history. Oecologia, 80(1): 19-26.

Buffington, L.C., and C.H. Herbel (1965) Vegetational changes on a semidesert grassland range from 1858 to 1963. Ecological Monographs, 35(2): 139164.

Bulloch, H.E., Jr., and R.E. Neher (1980) Soil survey of Dona Ana county area, New Mexico. Bulletin 177, U.S. Department of Agriculture, Soil Conservation Service, Washington, D.C.

Campbell, B.D., J.P. Grime, and J.M.L. Mackey (1991) A trade-off between scale and precision in resource foraging. Oecologia, 87: 532-538.

Canfield, R.H. (1957) Reproduction and life span of some perennial grasses of southern Arizona. Journal of Range Management, 10(5): 199-203.

Childress, W.M., C.L. Coldren, and T. McLendon (2002) Applying a complex, general ecosystem model (EDYS) in large-scale land management. Ecological Modelling, 153(1): 97-108. 
Coffin, D.P., and W.K. Lauenroth (1988) The effect of disturbance size and frequency on a shortgrass plant community. Ecology, 69: 1609-1617.

Coffin, D.P., and W.K. Lauenroth (1989) Disturbance and gap dynamics in a semiarid grassland: A landscape-level approach. Landscape Ecology, 3: 19-27.

Cole, D.N. (1995) Experimental trampling of vegetation: 2. Predictors of resistance and resilience. Journal of Applied Ecology, 32(1): 215-224.

Cole, D.N., and N.G. Bayfield (1993) Recreational trampling of vegetationStandard experimental procedures. Biological Conservation, 63(3): 209-215.

Dodd, M.B., W.K. Lauenroth, and J.M. Welker (1998) Differential water resource use by herbaceous and woody plant life-forms in a shortgrass steppe community. Oecologia, 117(4): 504-512.

Eissenstat, D.M., and M.M. Caldwell (1988) Competitive ability is linked to rates of water extraction: A field study of two arid land tussock grasses.

Oecologia, 75: 1-7.

Fehmi, J.S., T. Farmer, and J.A. Zimmerman (2001) Impacts of military vehicle training activities on vegetation: Bibliography with abstracts. ERDC/CERL SR-01-17, U.S. Army Engineer Research and Development Center, Construction Engineering Research Laboratory, Champaign, IL.

Fitter, A.H. (1994) Architecture and biomass allocation as components of the plastic response of root systems to soil heterogeneity. In Exploitation of Environmental Heterogeneity by Plants (M.M. Caldwell and R.W. Pearcy, ed.). San Diego: Academic Press, p. 305-323.

Gibbens, R.P., and J.M. Lenz (2001) Root systems of some Chihuahuan desert plants. Journal of Arid Environments, 49(2): 221-263.

Gibbens, R.P., and R.F. Beck (1988) Changes in grass basal area and forb densities over a 64-year period on grassland types of the Jornada Experimental Range. Journal of Range Management, 41(3): 186-192.

Gile, L.H., and R.B. Grossman (1997) The Desert Project Soil Monograph. Natural Resources Conservation Service, USDA National Soil Survey Center, Lincoln, NE.

Gill, R.A., and R.B. Jackson (2000) Global patterns of root turnover for terrestrial ecosystems. New Phytologist, 147(1): 13-31.

Gill, R.A., I.C. Burke, W.K. Lauenroth, and D.G. Milchunas (2002) Longevity and turnover of roots in the shortgrass steppe: Influence of diameter and depth. Plant Ecology, 159(2): 241-251 . 
Gillette, D.A., and J. Adams (1983) Accelerated wind erosion and prediction of rates. In Environmental Effects of Off-road Vehicles. Impacts and Management in Arid Regions (R.H. Webb and H.G. Wilshire, ed.). New York: Springer Verlag, p. $97-109$.

Goran, W.D., L.L. Radke, and W.D. Severinghaus (1983) An overview of the ecological effects of tracked vehicles on major U.S. Army installations. ERDC/CERL N-142, U.S. Army Engineer Research and Development Center, Construction Engineering Research Laboratory, Champaign, IL.

Grover, H.D., and H.B. Musick (1990) Shrubland encroachment in southern New Mexico, USA. An analysis of desertification processes in the American Southwest. Climatic Change, 17(2-3): 305-330.

Herbel, C.H., F.N. Ares, and R.A. Wright (1972) Drought effects on a semidesert grassland range. Ecology, 53(6): 1084-1093.

Herrick, J.E., and J. Belnap (2002) Sustainable disturbance levels of military training on gypsic soil (Phase II). Final report. Holloman Air Force Base.

Hochstrasser, T., G. Kröel-Dulay, D.P.C. Peters, and J.R. Gosz (2002a) Vegetation and climate characteristics of arid and semi-arid grasslands in North America and their biome transition zone. Journal of Arid Environments, 51(1): $55-78$.

Hochstrasser, T., D.P.C. Peters, J.S. Fehmi, and K. VonFinger (2002b) A bibliography of important plant species in the Chihuahuan Desert of North America (1904-2002). ERDC/CERL SR-02-08, U.S. Army Engineer Research and Development Center, Construction Engineering Research Laboratory, Champaign, IL.

Hochstrasser, T., and D.P.C. Peters (Submitted) Subdominant species distribution in microsites around two lifeforms at a desert grassland-shrubland transition zone. Journal of Vegetation Science.

Hochstrasser, T., D.P.C. Peters, and J.S. Fehmi (In prep.) Determining research gaps in disturbance data for Fort Bliss and a conceptual model. Technical Report, U.S. Army Engineer Research and Development Center, Construction Engineering Research Laboratory, Champaign, IL.

Jackson, R.B., J. Canadell, J.R. Ehleringer, H.A. Mooney, O.E. Sala, and E.D. Schulze (1996) A global analysis of root distributions for terrestrial biomes. Oecologia, 108(3): 389-411.

Jackson, R.B., H.A. Mooney, and E.-D. Schulze (1997) A global budget for fine root biomass, surface area, and nutrient contents. Proceedings of the National Academy of Science of the United States of America, 34: 7362-7366. 
Lathrop, E.W. (1983) The effect of vehicle use on desert vegetation. In Environmental Effects of Off-road Vehicles. Impacts and Management in Arid Regions (R.H. Webb and H.G. Wilshire, ed.). New York: Springer Verlag, p. 153-166.

Luo, Y., P.A. Meyerhoff, and R.S. Loomis (1995) Seasonal patterns and vertical distributions of fine roots of alfalfa (Medicago sativa L.). Field Crops Research, 40(2): 119-127.

Mabry, T.J., J.H. Hunziker, and D.R. DiFeo, Jr. (1977) Larrea and its Role in Desert Ecosystems. Stroudsburg, PA: Dowden, Hutchinson and Ross.

McIntyre, S., S. Lavorel, J. Landsberg, and T.D.A. Forbes (1999) Disturbance response in vegetation-Towards a global perspective on functional traits. Journal of Vegetation Science, 10(5): 621-630.

Miller, R.E., and L.F. Huenneke (2000) Demographic variation in a desert shrub, Larrea tridentata, in response to a thinning treatment. Journal of Arid Environments, 45: 315-323.

Neilson, R.P. (1986) High-resolution climatic analysis and southwest biogeography. Science, 232: 27-34.

Nelson, E.W. (1934) The influence of precipitation and grazing upon black grama grass range. Technical Bulletin no. 409, U.S. Dept. of Agriculture, p. 132.

Neuenschwander, L.H., S.H. Sharrow, and H.A. Wright (1975) Review of Tobosa grass (Hilaria mutica). Southwestern Naturalist, 20(2): 255-263.

Parmenter, R.R., and J.A. MacMahon (1983) Factors determining the abundance and distribution of rodents in a shrub-steppe ecosystem: The role of shrubs. Oecologia, 59: 145-156.

Partel, M., and S.D. Wilson (2002) Root dynamics and spatial pattern in prairie and forest. Ecology, 83(5): 1199-1203.

Parton, W.J. (1978) Abiotic section of ELM. In Grassland Simulation Model (G.S. Innis, ed.). New York: Springer Verlag, p. 31-53.

Paulsen, H.A., Jr., and F.N. Ares (1962) Grazing values and management of black grama and tobosa grasslands and associated shrub ranges of the Southwest. Technical Bulletin no. 1270, U.S. Dept. of Agriculture, Forest Service.

Peltzer, D.A., and M. Köchy (2001) Competitive effects of grasses and woody plants in mixed-grass prairie. Journal of Ecology, 89(4): 519-527. 
Peters, D.P.C. (2002) Plant species dominance at a grassland-shrubland ecotone: An individual-based gap dynamics model of herbaceous and woody species.

Ecological Modelling, 152(1): 5-32.

Peters, D.P.C., and J.E. Herrick (2002) Modelling vegetation change and land degradation in semiarid and arid ecosystems: An integrated hierarchical approach. Advances in Environmental Monitoring and Modelling, http://www.kcl.ac.uk/advances.

Pidgeon, A.M., N.E. Mathews, R. Benoit, and E.V. Nordheim (2001) Response of avian communities to historic habitat change in the northern Chihuahuan Desert. Conservation Biology, 15(6): 1772-1788.

Pidgeon, A.M. (2000) Avian abundance and productivity at the landscape scale in the northern Chihuahuan Desert. Ph.D. dissertation, University of Wisconsin.

Sala, O.E., W.K. Lauenroth, and R.A. Golluscio (1997) Plant functional types in temperate arid regions. In Plant Functional Types: Their Relevance to Ecosystem Properties and Global Change (T.M. Smith, H.H. Shugart, and F.I. Woodward, ed.). Cambridge, New York: Cambridge University Press, p. 217233.

Schlesinger, W.H., J.F. Reynolds, G.L. Cunningham, L.F. Huenneke, W.M. Jarrell, R.A. Virginia, and W.G. Whitford (1990) Biological feedbacks in global desertification. Science, 247: 1043-1048.

Schlesinger, W.H., J.A. Raikes, A.E. Hartley, and A.F. Cross (1996) On the spatial pattern of soil nutrients in desert ecosystems. Ecology, 77(2): 364-374.

Shugart, H.H. (1984) A Theory of Forest Dynamics. New York: Springer.

Simpson, B.B. (1977) Mesquite, Its Biology in Two Desert Scrub Ecosystems. US/IBP Synthesis Series, 4. Stroudsburg, Pa., New York: Dowden, Hutchinson and Ross; exclusive distribution, Halsted Press.

Smith, S.D., R.K. Monson, and J.E. Anderson (1997) Physiological Ecology of North American Desert Plants. Adaptations of Desert Organisms (J.L.

Cloudsley-Thompson, ed.). Berlin: Springer.

Sun, G., D.P. Coffin, and W.K. Lauenroth (1997) Comparison of root distributions of species in North American grasslands using GIS. Journal of Vegetation Science, 8(4): 587-596.

Taylor Soltero, H. (1996) Comparison of field methods and procedures to estimate termite activity in the Northern Chihuahuan desert. M.S. Thesis. University of Texas, El Paso. 
Walker, B.H., and I. Noy-Meir (1982) Aspects of the stability and resilience of savanna ecosystems. Ecology of Tropical Savannas (B.J. Huntley and B. H. Walker, ed.). New York: Springer Verlag, p. 556-590.

Webb, R.H., J.W. Steiger, and H.G. Wilshire (1986) Recovery of compacted soils in Mojave Desert ghost towns. Soil Science Society of America Journal, 50(5): 1341-1344.

Weiher, E., A. van der Werf, K. Thompson, M. Roderick, E. Garnier, and O. Eriksson (1999) Challenging Theophrastus: A common core list of plant traits for functional ecology. Journal of Vegetation Science, 10(5): 609-620.

Whitford, W.G. (1997) Desertification and animal biodiversity in the desert grasslands of North America. Journal of Arid Environments, 37(4): 709-720.

Wierenga, P.J., J.M.H. Hendrickx, M.H. Nash, J. Ludwig, and L.A.

Daugherty (1987) Variation of soil and vegetation with distance along a transect in the Chihuahuan Desert. Journal of Arid Environments, 13: 53-63.

Wilson, J.B., and A.D.Q. Agnew (1992) Positive-feedback switches in plant communities. In Advances in Ecological Research, 23 ed. (M. Begon and A.H. Fitter, ed.). London: Academic Press, p. 263-336.

Wilson, S.D. (1998) Competition between grasses and woody plants. In Population Biology of Grasses (G.P. Cheplick, ed.). Cambridge, UK: Cambridge University Press, p.231-254.

Wondzell, S.M., G.L. Cunningham, and D. Bachelet (1996) Relationships between landforms, geomorphic processes, and plant communities on a watershed in the northern Chihuahuan Desert. Landscape Ecology, 11(6): 351-362.

Wright, R.G., and G.M. Van Dyne (1976) Environmental factors influencing semidesert grassland perennial grass demography. Southwestern Naturalist, 21(3): 259-274.

Yorks, T.P., N.E. West, R.J. Mueller, and S.D. Warren (1997) Tolerance of traffic by vegetation: Life form conclusions and summary extracts from a comprehensive database. Environmental Management, 21(1): 121-131. 


\section{APPENDIX A. KEYWORDS FOR LITERATURE DATABASE ON DOMINANT SPECIES AT THE JORNADA EXPERIMENTAL RANGE}

These keywords were used for the ProCite database (named SPECIES) assembled by Tamara Hochstrasser, 2002-2003. Since the objective of this database was to gather ecological information on dominant plant species at the Jornada Experimental Range, the classification of keywords was done from the perspective of plant ecology, i.e. categories get broader as the focus shifts away from the plant. For some keywords we entered alternative keywords into this document to show how references were grouped. When this is the case, the keyword used is underlined.

The purpose of the assignment of keywords was to create broad classes of publications. To achieve this we devised a hierarchical system of keywords. There are three broad categories that have variable keyword entries. They are to give a general description of the study system and the organisms studied. These three categories are:

Scientific name, or Mosses, Lichens, Soil crust

Location: Country/U.S. state, Name of desert, Continent (if NOT North

America), Study site (e.g. Jornada, Sevilleta, Santa Rita, etc.)

Vegetation type (as precisely as possible): e.g. grasslands, steppe, desert grasslands

Apart from these three broad categories with variable entries, there are also another five broad categories that have fixed entries. These eight categories are considered the "top level." The five categories with fixed keyword entries are Species characteristics, Community characteristics, Kind of study, Disturbance, and Land use. Within each of these five categories, attempts have been made to arrange fixed keywords in a hierarchical fashion. Each reference is assigned keywords at the highest hierarchical level first (i.e. from the top level). If there is more precise information, keywords from lower hierarchical levels are added until further resolution does not improve information. The idea is to give the user a way to roughly classify references, before more detail is added. To prevent the classification of references into these broad categories from being made unclear, a reference in one broad category may contain low-level keywords from some other broad category. For example, a reference that belongs in the broad category of "Plant physiology," may also contain the keyword "soil water content."

These broad classifications will help people who are looking for references concerning some subject matter for which we have not used a keyword. In such a case the user can choose the broad categories that fit the references he/she is 
looking for and add their own lower-level keyword as they find references relevant to the subject matter. References that are very narrow in focus will have a keyword from one of the top levels and then the lower-level specific keyword, without all the intermediary categories. For example, if a reference reports the specific leaf area of a plant, it will be classified in "Morphology: Leaf area index" and NOT in "Morphology: Plant architecture: Surface: biomass ratio: Leaf area index."

The hierarchical classification of keywords may cause trouble, because the classification is obviously quite subjective, and other people may come up with a different hierarchy. When looking for a specific keyword, it is therefore recommended to use this list electronically such that keywords can be identified regardless of their hierarchical level. The same is true for the ProCite database, which should be able to search for specific keywords (as long as they are in the list), regardless of their hierarchical level.

\section{SPECIES CHARACTERISTICS}

1. Morphology

2. Life History, Demography

3. Physiology, Growth

4. Chemistry

5. Genetics

6. Effects on Environmental Fluxes

7. Distribution

8. Mutualism

\section{I.1. Morphology}

\section{I.1.1. Lifeform}

Raunkiaer lifeform

I.1.2. Plant size

(Position of dormant buds)

Biomass

above-ground biomass

below-ground biomass

total biomass

biomass of seedling

Size distribution

within population

age-size distribution

I.1.3. Plant architecture

size-biomass relationship

Canopy architecture

branching angles 
plant height

leaf morphology

Root distribution

depth of maximum root biomass

maximum rooting depth

root biomass distribution function

Surface: biomass ratio

leaf area index

specific leaf area

root surface:biomass ratio

Size of different plant organs

root:shoot ratio

leaf:stem ratio

reproductive:vegetative

fine:coarse root ratio

1.1.4. Seed morphology

Seed mass, seed weight

Seed shape

Seed surface

1.1.5. Plasticity

\section{I.2. Life History, Demography}

\section{I.2.1. Regeneration}

Reproductive age

Pollination

pollination mode

pollination efficiency

Dispersal

dispersal mode

dispersal distance

Seed bank

spatial distribution

seed bank persistence

Germination

minimum water potential for germination

temperature for germination

time of germination

Establishment

(seedling survival)

germination:establishment ratio

time of establishment

weather conditions for establishment

Vegetative reproduction

importance of vegetative reproduction

Sprouting

amount of resprouting 
I.2.2. Mortality

(see also DISTURBANCE)

Lifespan

Plasticity

Timing of mortality

I.2.3. Population dynamics

Reproductive rate

Life stages

Growth rate

Mortality rate

\section{I.3. Physiology, Growth}

\section{I.3.1. Phenology}

Leaf production

Root production fine root production coarse root production

Flowering

Seed production timing amount of seed production

Leaf turnover leaf longevity

leaf age timing

Root turnover total root turnover fine root turnover coarse root turnover

Timing of seed release

I.3.2. Carbon fixation

Primary productivity

Photosynthesis photosynthetic pathway optimal temperature for growth effect of shading

Respiration photoperiod

Transpiration

WUE

water uptake

plant water potential

\section{I.3.3 Nutrient uptake}

Nitrogen fixation

Nitrogen uptake

NUE

Phosphorus uptake 
Potassium uptake

1.3.4. Allocation

Carbon allocation carbon storage carbon transport

Nitrogen allocation nitrogen reabsorption nitrogen transport

Plant hormones

I.3.5 Trade-off

\section{I.4. Chemistry}

I.4.1. Biomass composition

$\mathrm{C}: \mathrm{N}$ ratio

Lignin content

Carbon content

Nitrogen content, amino acids

Litter composition

I.4.2. Secondary compounds

1.4.3. Caloric content

\section{I.5. Genetics}

1.5.1. Ecotypes

1.5.2. Population level variability

I.5.3. Species level variability

\section{I.6. Effects on Environmental Fluxes}

\subsubsection{Effects of canopy} Interception

Shading

1.6.2. Effects of litter

1.6.3. Effects of roots

\section{I.7. Distribution}

I.7.1. Range

I.7.2. Climatic constraints

I.7.3. Soil constraints

Soil texture

Caliche

I.7.4 Elevation

I.7.5. Spatial pattern

1.7.6. Aspect

\section{I.8. Mutualism}

I.8.1. Mycorrhizae

I.8.2. Plant-animal interaction 


\section{COMMUNITY CHARACTERISTICS}

1. Vegetation structure

2. Soil properties

3. Animal community

4. Microsites

5. Plant-plant interaction

6. Carbon dynamics

7. Water dynamics

8. Nutrient dynamics

9. Light

10. Biotic-abiotic feedbacks

\section{II.1. Vegetation structure}

II.1.1. Community composition

Cover

Density

Species richness

Functional groups

Species list

Exotics

II.1.2. Succession

State and transition model

Shrub encroachment

Ecotone

\section{II.2. Soil properties}

II.2.1 Surface soil

II.2.2. Soil profile

II.2.3. Geomorphology

\section{II.3. Animal community}

II.3.1. Micro-arthropods

II.3.2. Rodents

\section{II.4. Microsites}

II.4.1. Plant coexistence pattern

II.4.2. Micrometeorology

Temperature

Soil moisture

II.4.3. Microtopography 


\title{
II.5. Plant-plant interaction
}

\author{
II.5.1. Competition \\ Water relations \\ Allelopathy \\ II.5.2. Facilitation
}

\section{II.6. Carbon dynamics}

\section{II.6.1. Amount of litter}

II.6.2. Litter decomposition

Buried

fungal microbial

Surface

termites abiotic decomposition

II.6.3. Carbon distribution

Microbial biomass

II.6.4. Carbon cycling in soil

Microbial

Fungal

II.6.5. Carbon dioxide fluxes

\section{II.7. Water dynamics}

\section{II.7.1 Evapotranspiration}

Potential

Actual

II.7.2. Water balance

Actual evaporation

Run-off

(for Transpiration see Species Characteristics $\rightarrow$ Physiology)

(for Interception see Species Characteristics $\rightarrow$ Effects on

Infiltration environmental fluxes)

Soil water dynamics

II.7.3. Soil water content, Soil moisture content

Content

Soil water potential

Soil moisture-soil water potential

Groundwater table

II.7.4. Climate data

Precipitation

Temperature

soil temperature

Relative humidity, vapor pressure deficit

Wind speed 


\section{II.8. Nutrient dynamics}

II.8.1. Nitrogen

Nitrogen distribution

Nitrogen cycling in soil

Ammonium volatilization

II.8.2. Phosphorus

Phosphorus distribution

Phosphorus cycling

II.8.3. Potassium

Potassium distribution

Potassium cycling in soil

II.8.4. Other chemical elements in soil

\section{II.9. Light}

II.9.1. Albedo

II.9.2. Light absorption

\section{II.10. Biotic-abiotic feedbacks}

II.10.1. Desertification

II.10.2. Indirect effects

\section{KIND OF STUDY}
1. Observation
2. Experiment
3. Modeling
4. Review

\section{III.1. Observation}

Field survey

Remote sensing

Label

Long-term

III.2. Experiment

Greenhouse

Plant removal

Amendment 
Exclosure

Isotopes

Rainfall simulation, irrigation

Remediation

\section{III.3. Modelling}

Deterministic

Stochastic

III.4 Review

\section{DISTURBANCE}

1. Generic disturbance

2. Fire

3. Herbivory

4. Granivory

5. Digging

6. Extreme events

7. Erosion

8. Dust

9. Restoration

\section{IV.1. Generic disturbance}

IV.1.1. General disturbance characteristics

IV.1.2. Disturbance history

IV.1.3. Disturbance interaction (i.e. interaction between disturbances)

IV.2. Fire

IV.3. Herbivory

Clipping

Insects

Rodents

kangaroo rats

Lagomorphs 
IV.4. Granivory

Insects

Rodents

kangaroo rats

Ants

IV.5. Digging

Rodents

kangaroo rats

Lagomorphs

IV.6. Extreme events

Drought

Temperature stress

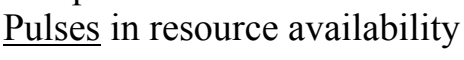

IV.7. Erosion

Wind, aeolian

Water

IV.8. Dust

IV.9. Restoration

\section{LAND USE}

1. Grazing

2. Military

3. Roads

4. Brush control

5. Multiple land use

V.1. Grazing

V.1.1. Cattle

Nutrition

diet needs 


\author{
diet composition \\ palatability \\ Toxicity \\ Behavior \\ Trampling effects \\ Management \\ V.1.2. Sheep \\ V.1.3. Goats \\ V.1.4. Plant response \\ Hormonal responses \\ Chemical responses
}

\title{
V.2. Military
}

V.2.1. Tanks

V.2.2. Bombs

V.2.3. Infantry

\section{V.3. Roads}

V.3.1. Off-road vehicles

V.3.2. Hiking trails

\section{V.4. Brush control}

V.4.1. Mechanical

V.4.2. Herbicide

V.4.3. Techniques

\section{V.5. Multiple land use}

V.5.1. Land use - disturbance interaction

V.5.2. Land use history

V.5.3. Interactive effects of different land management 


\section{APPENDIX B. SPECIES CHARACTERISTICS OF THE DOMINANT SPECIES AT THE JORNADA EXPERIMENTAL RANGE}

The tables contain information on the ecological characteristics of the dominant species of the Jornada as found in the literature.

List of tables:

Table B1. Key references

Table B2. Habitat of species

Table B3. Life history and morphology

Table B4. Root distribution

Table B5. Seed production, dispersal

Table B6. Recruitment characteristics

Table B7. Phenology and growth

Table B1. Key references.

\begin{tabular}{|c|c|}
\hline Species name & References \\
\hline $\begin{array}{l}\text { Bouteloua eriopoda } \\
\text { (BOER) }\end{array}$ & $\begin{array}{l}\text { 1. Simonin, K.A. (2000) U.S. Department of Agriculture, Forest Services, Rocky } \\
\text { Mountain Research Station, FSL. http://www.fs.fed.us/database/feis/ } \\
\text { 2. }(84) \\
\text { 3. }(85,86) \\
\text { 4. (73) } \\
\text { 5. (69) }\end{array}$ \\
\hline $\begin{array}{l}\text { Pleuraphis mutica } \\
\text { (PLMU) }\end{array}$ & $\begin{array}{l}\text { 1. Uchytil, R.J. (1988) U.S. Department of Agriculture, Forest Services, Rocky } \\
\text { Mountain Research Station, FSL. http://www.fs.fed.us/database/feis/ } \\
\text { 2. (73) } \\
\text { 3. (70) }\end{array}$ \\
\hline $\begin{array}{l}\text { Flourensia cernua } \\
\text { (FLCE) }\end{array}$ & $\begin{array}{l}\text { 1. Korthuis, S.L. (1988) U.S. Department of Agriculture, Forest Services, Rocky } \\
\text { Mountain Research Station, FSL. http://www.fs.fed.us/database/feis/ }\end{array}$ \\
\hline $\begin{array}{l}\text { Prosopis glandulosa } \\
\text { (PRGL) }\end{array}$ & $\begin{array}{l}\text { 1. Steinberg, P. (2001). U.S. Department of Agriculture, Forest Services, Rocky } \\
\text { Mountain Research Station, FSL. http://www.fs.fed.us/database/feis/ } \\
\text { 2. (83) p. 167-174 } \\
\text { 3. (77) } \\
\text { 4. (82) }\end{array}$ \\
\hline $\begin{array}{l}\text { Larrea tridentata } \\
\text { (LATR) }\end{array}$ & $\begin{array}{l}\text { 1. Marshall, K.A. (1995) Korthuis, S.L. (1988) U.S. Department of Agriculture, } \\
\text { Forest Services, Rocky Mountain Research Station, FSL. } \\
\text { http://www.fs.fed.us/database/feis/ } \\
\text { 2. (83) p. 93-106 } \\
\text { 3. (76) } \\
\text { 4. (92) } \\
\text { 5. (10) }\end{array}$ \\
\hline
\end{tabular}


Table B2. Habitat of species.

\begin{tabular}{|c|c|c|c|}
\hline Abbrev. & Habitat & Soil types & Elevation \\
\hline BOER & Desert grasslands* & Well-drained sandy and gravelly soils ${ }^{\dagger}$ & $\begin{array}{l}\text { AZ: } 914-1524 \mathrm{~m} \\
\text { CA: } 800-1,900 \mathrm{~m} \\
\text { CO: } 1,340-1,460 \mathrm{~m}\end{array}$ \\
\hline PLMU & Playa grasslands ${ }^{\dagger}$ & Relatively impervious clay soils** & $\begin{array}{l}\text { AZ: } 750-1800 \mathrm{~m} \\
\text { NM: } 914-1,981 \mathrm{~m} \\
\text { UT: } 488-853 \mathrm{~m}\end{array}$ \\
\hline FLCE & Desert shrublands ${ }^{\star \star}$ & Clay - clay loam soils ${ }^{\dagger \dagger}$ & $\begin{array}{l}400-1,981 \mathrm{~m} \text { in } \\
\text { Chihuahuan desert }\end{array}$ \\
\hline PRGL & Desert shrublands ${ }^{\dagger \dagger}$ & $\begin{array}{l}\text { Wide variety of soils including loamy sand, sandy } \\
\text { loam, calcareous silt loam, noncalcareous silt } \\
\text { loam, gravelly sand loam, deep sandy loam, and } \\
\text { calcareous clay*** } \\
\text { Positively correlated with soil depth (65) }\end{array}$ & $<1,387 \mathrm{~m}$ \\
\hline LATR & Desert shrublands*** & $\begin{array}{l}\text { Calcareous, sandy, and alluvial soils with underlain } \\
\text { caliche hardpan }{ }^{\star \star \star} \\
\text { Absent from soils with strong argilic horizon (59) }\end{array}$ & $\begin{array}{l}<1,515 \mathrm{~m} \text { in all } \\
\text { deserts }\end{array}$ \\
\hline
\end{tabular}

*Simonin, K. A. (2000). U.S. Department of Agriculture, Forest Services, Rocky Mountain Research Station, FSL. http://www.fs.fed.us/database/feis/

†Uchytil, R. J. (1988). U.S. Department of Agriculture, Forest Services, Rocky Mountain Research Station, FSL. http://www.fs.fed.us/database/feis/

**Korthuis, S. L. (1988). U.S. Department of Agriculture, Forest Services, Rocky Mountain Research Station, FSL. http://www.fs.fed.us/database/feis/

${ }^{\dagger \dagger}$ Steinberg, P. (2001). U.S. Department of Agriculture, Forest Services, Rocky Mountain Research Station, FSL. http://www.fs.fed.us/database/feis/

${ }^{\star * \star M}$ Marshall, K. A. (1995). Korthuis, S. L. (1988). U.S. Department of Agriculture, Forest Services, Rocky Mountain Research Station, FSL. http://www.fs.fed.us/database/feis/ 
Table B3. Life history and morphology.

\begin{tabular}{|c|c|c|c|c|c|c|c|c|}
\hline Abbrev. & Lifespan & Lifeform & $\begin{array}{l}\text { Plant size } \\
\text { distrib. }\end{array}$ & $\begin{array}{l}\text { Net primary } \\
\text { productivity }\end{array}$ & $\begin{array}{c}\text { Size/biomass } \\
\text { relationship }\end{array}$ & Full-grown above-ground biomass & $\begin{array}{l}\text { Root:shoot } \\
\text { ratio }\end{array}$ & Leaf: stem ratio \\
\hline BOER & $\begin{array}{l}35-40 \text { years* } \\
\text { Individual tillers seem to live } \\
\text { about } 2 \text { years (43) } \\
\text { Max. } 28 \text { years (98) } \\
4 \% \text { of a cohort lived for } 14 \\
\text { years (31) }\end{array}$ & \begin{tabular}{|l|} 
Perennial \\
grass
\end{tabular} & $\begin{array}{l}(75) \\
(69)\end{array}$ & $\begin{array}{l}38-63 \mathrm{~g} / \mathrm{m}^{2} / \\
\text { growing } \\
\text { season (6) }\end{array}$ & (86) & $\begin{array}{l}371.98 \mathrm{~g} / \mathrm{m}^{2}(33) \\
262 \mathrm{~g} / \mathrm{m}^{2}(79) \\
19.8-72.8 \mathrm{~g} / \mathrm{m}^{2} \text { (depending on } \\
\text { cover) }(96) \\
378 \mathrm{~g} / \text { plant (85) }\end{array}$ & $\begin{array}{l}1.45(79) \\
0.3(86)\end{array}$ & \\
\hline PLMU & $\begin{array}{l}\text { Max. } 7 \text { years }(98) \\
\text { Pleuraphis rigida lives over } \\
100 \text { years (24) }\end{array}$ & \begin{tabular}{|l|} 
Perennial \\
grass
\end{tabular} & & $\begin{array}{l}112.2 \mathrm{~g} / \mathrm{m}^{2} \\
\text { (yields) }(70)\end{array}$ & & $\begin{array}{l}311 \mathrm{~g} / \mathrm{m}^{2}(51) \\
136 \mathrm{~g} / \mathrm{m}^{2}(37) \\
207 \mathrm{~g} / \mathrm{m}^{2}(1) \\
204 \mathrm{~g} / \mathrm{m}^{2}\left(1980,26 \mathrm{~g} / \mathrm{m}^{2} \text { green }\right), 210 \\
\mathrm{~g} / \mathrm{m}^{2}\left(1981,23 \mathrm{~g} / \mathrm{m}^{2} \text { green }\right)(2)\end{array}$ & & \\
\hline FLCE & & $\begin{array}{l}\text { Perennial } \\
\text { shrub }\end{array}$ & & & (56) & $164 \mathrm{~g} / \mathrm{m}^{2}(79)$ & & \\
\hline PRGL & $100-200$ years $^{\dagger}$ & $\begin{array}{l}\text { Perennial } \\
\text { shrub }\end{array}$ & $\begin{array}{l}\text { (81) } \\
(5)\end{array}$ & $\begin{array}{l}17.8 \mathrm{~kg} / \mathrm{plant} / \mathrm{yr} \\
\text { or } 0.78 \\
\mathrm{~kg} / \mathrm{m}^{2} / \mathrm{yr}(81)\end{array}$ & $\begin{array}{l}(14) \\
(56)\end{array}$ & $\begin{array}{l}258 \mathrm{~g} / \mathrm{m}^{2}(79) \\
6.2 \mathrm{~kg} / \mathrm{shrub} \text { or } 155.2 \mathrm{~g} / \mathrm{m}^{2}(14) \\
219 \mathrm{~kg} \text { (big shrub) }(50) \\
43-760 \mathrm{~kg} / \mathrm{shrub} \text { or } 1.9-8.5 \mathrm{~kg} / \mathrm{m}^{2} \text { of } \\
\text { canopy area (81) }\end{array}$ & & $\begin{array}{l}0.19(14) \\
0.03(50) \\
0.12, \text { but leaf production } \\
\text { is } 31.6 \% \text { of total } \\
\text { production (81) } \\
\text { (current growth \& } \\
\text { leaves) } / \text { (branches and } \\
\text { wood) }=0.17 \text { (Jornada) } \\
(15)\end{array}$ \\
\hline LATR & $\begin{array}{l}\text { very long lived }{ }^{\star \star} \\
\text { (Chihuahuan Desert } \\
\text { ca. } 430 \text { years) }(61) \\
\text { Over } 100 \text { years }(24) \\
11,700(94) \\
1,250(58)\end{array}$ & $\begin{array}{l}\text { Perennial } \\
\text { shrub }\end{array}$ & $\begin{array}{l}(75) \\
(41) \\
(59) \\
(13) \\
(49) \\
(7) \\
(9) \\
(11) \\
(28)\end{array}$ & $\begin{array}{l}350-385 \mathrm{~kg} \text { dry } \\
\text { wt / ha }(10) \\
910 \mathrm{~kg} / \mathrm{ha} / \mathrm{yr} \\
\text { (California) or } \\
917 \mathrm{~kg} / \mathrm{ha} / \mathrm{yr} \\
\text { (Arizona) (81) }\end{array}$ & $\begin{array}{l}(62) \\
(29) \\
(56)\end{array}$ & $\begin{array}{l}60-299 \mathrm{~kg} / \mathrm{ha} \text { (Mojave) (13) } \\
252.56 \mathrm{~g} / \mathrm{m}^{2}(33) \\
204 \mathrm{~g} / \mathrm{m}^{2}(79) \\
330 \mathrm{~g} / \mathrm{m}^{2} \text { (California) } 389 \mathrm{~g} / \mathrm{m}^{2} \\
\text { (Arizona) (81) } \\
120-1,820 \mathrm{~g} / \text { plant (29) }\end{array}$ & $\begin{array}{l}0.64-6.78 \\
(\text { mean } 2.4) \text { or } \\
0.2-2.7 \\
(\text { mean } 0.9) \\
(10) \\
0.22-2.5(76) \\
0.33(44)\end{array}$ & $\begin{array}{l}45-70 \% \text { of above-ground } \\
\text { vegetative production is } \\
\text { allocated to leaves (10) } \\
0.42(44)\end{array}$ \\
\hline
\end{tabular}

* Simonin, K. A. (2000). U.S. Department of Agriculture, Forest Services, Rocky Mountain Research Station, FSL. http://www.fs.fed.us/database/feis/

† Steinberg, P. (2001). U.S. Department of Agriculture, Forest Services, Rocky Mountain Research Station, FSL. http://www.fs.fed.us/database/feis/

** Marshall, K. A. (1995). Korthuis, S. L. (1988). U.S. Department of Agriculture, Forest Services, Rocky Mountain Research Station, FSL. http://www.fs.fed.us/database/feis/ 
Table B4. Root distribution. We did not find any information on fine:coarse root ratio, Fine root surface: biomass ratio, Coarse root surface: biomass ratio, or fine root turnover rate. This is why we used more general information from the literature as described in the comparison between grasses and shrubs section.

\begin{tabular}{|c|c|c|c|}
\hline Abbrev. & $\begin{array}{c}\text { Depth of maximum } \\
\text { root biomass }\end{array}$ & Maximum rooting depth & $\begin{array}{l}\text { Root biomass distribution } \\
\text { function }\end{array}$ \\
\hline BOER & $5-25 \mathrm{~cm}^{*}$ & $\begin{array}{l}1.2 \mathrm{~m}^{\star} \\
1.6 \mathrm{~m} / \text { depth to caliche layer (45) } \\
1.22 \mathrm{~cm} \text { or more (73) }\end{array}$ & \\
\hline PLMU & 0-90 cm (73) & $\begin{array}{l}1.8 \mathrm{~m}^{\dagger}(73) \\
\text { Over } 1 \mathrm{~m} \text { (with caliche) (45) }\end{array}$ & $(66)$ \\
\hline FLCE & & $>5 \mathrm{~m} \mathrm{(45)}$ & $(66)$ \\
\hline PRGL & $\begin{array}{l}30 \mathrm{~cm}^{\star \star} \\
0-33 \mathrm{~cm}(50)\end{array}$ & $\begin{array}{l}12 m^{\star \star} \\
6-12 m \text { are common (78) }\end{array}$ & $(50,66)$ \\
\hline LATR & $20-35 \mathrm{~cm}^{\dagger \dagger}$ & $\begin{array}{l}80 \mathrm{~cm}^{\dagger \dagger} \\
>5 \mathrm{~m}(45)\end{array}$ & $(66)$ \\
\hline
\end{tabular}

*Simonin, K. A. (2000). U.S. Department of Agriculture, Forest Services, Rocky Mountain Research Station, FSL. http://www.fs.fed.us/database/feis/

Uchytil, R. J. (1988). U.S. Department of Agriculture, Forest Services, Rocky Mountain Research Station, FSL. http://www.fs.fed.us/database/feis/

**Steinberg, P. (2001). U.S. Department of Agriculture, Forest Services, Rocky Mountain Research Station, FSL. http://www.fs.fed.us/database/feis/

"Marshall, K. A. (1995). Korthuis, S. L. (1988). U.S. Department of Agriculture, Forest Services, Rocky Mountain Research Station, FSL. http://www.fs.fed.us/database/feis/ 
Table B5. Seed production and dispersal. Dispersal distance is an input parameter for ECOTONE that needs to be deduced from seed mass and falling velocity. There is no direct information on seed dispersal distance for these species.

\begin{tabular}{|c|c|c|c|c|c|c|c|c|c|c|}
\hline Abbrev. & $\begin{array}{c}\text { Main regeneration } \\
\text { mode }\end{array}$ & $\begin{array}{l}\text { Vegetative } \\
\text { reproduction? }\end{array}$ & $\begin{array}{c}\text { Reproductive } \\
\text { age }\end{array}$ & $\begin{array}{c}\text { Reproductive } \\
\text { allocation }\end{array}$ & $\begin{array}{c}\text { Pollination } \\
\text { mode }\end{array}$ & $\begin{array}{c}\text { Amount of seed } \\
\text { production }\end{array}$ & $\begin{array}{c}\text { Timing of } \\
\text { seed release }\end{array}$ & $\begin{array}{l}\text { Dispersal } \\
\text { mode }\end{array}$ & Seed mass & $\begin{array}{c}\text { Seed shapel } \\
\text { falling } \\
\text { velocity }\end{array}$ \\
\hline BOER & Stolons* (69) & $\begin{array}{l}\text { Stolons (30) } \\
\text { About } 10 \\
\text { stolons } / \mathrm{m}^{2} / \text { year } \\
(69) \\
8.3 \\
\text { stolons } / \mathrm{m}^{2} / \text { year } \\
\text { (63) }\end{array}$ & $\begin{array}{l}2 \text { years }^{\star} \\
51-74 \text { days after } \\
\text { germination in } \\
\text { green house } \\
\text { (natural } \\
\text { environment } 2 \\
\text { years) (72) }\end{array}$ & & & & $\begin{array}{l}\text { October - } \\
\text { early } \\
\text { November } \\
(69)\end{array}$ & & & \\
\hline PLMU & $\begin{array}{l}\text { Rhizomes }^{\dagger} \\
\text { In the field few } \\
\text { seedlings survive } \\
(70)\end{array}$ & $\begin{array}{l}\text { Rhizomes (30, } \\
73 \text { ) }\end{array}$ & & & & $\begin{array}{l}\text { Few fertile seeds, } \\
\text { because of high } \\
\text { fungal infection } \\
\text { rate }(70)\end{array}$ & & & & \\
\hline FLCE & \begin{tabular}{|l|} 
Seeds/ \\
vegetative \\
spread $^{\star \star}$
\end{tabular} & & & & & & & Wind, Water** & & \\
\hline PRGL & $\begin{array}{l}\text { Seeds }{ }^{\dagger \dagger} \\
\text { Seeds only (90) }\end{array}$ & $\begin{array}{l}\text { Sprouting of } \\
\text { buried stems } \\
\text { (48) }\end{array}$ & 3 years & & $\begin{array}{l}\text { insects } \\
\text { (bees)* }^{*}\end{array}$ & $\begin{array}{l}\text { Can be reduced } \\
\text { by drought or } \\
\text { freezing (48) }\end{array}$ & $\begin{array}{l}\text { Late spring/ } \\
\text { early summer } \\
\text { (AZ, NM) (48) }\end{array}$ & $\begin{array}{l}\text { Animals* } \\
\text { Domestic } \\
\text { livestock, } \\
\text { rodents, water } \\
\text { (48) } \\
\text { Livestock (25, } \\
28 \text { ) }\end{array}$ & & \\
\hline LATR & $\begin{array}{l}\text { Vegetative } \\
\text { growth / } \\
\text { rarely seeds } \\
\text { Mostly seeds (48) }\end{array}$ & $\begin{array}{l}\text { Sprouting of } \\
\text { buried stems } \\
\text { and exposed } \\
\text { roots (48) }\end{array}$ & $\begin{array}{l}\text { Shrubs }<40 \mathrm{~cm} \\
\text { high did not } \\
\text { produce flowers } \\
\text { (42) } \\
\text { After } 5-13 \text { years } \\
\text { (48) } \\
13 \text { years (32) }\end{array}$ & $\begin{array}{l}\text { Reproductive } \\
\text { growth/ total } \\
\text { growth } 0.18- \\
0.8(35) \\
\text { Reproductive } \\
\text { growth/ total } \\
\text { growth } 0.1 \text { - } \\
0.8(40)\end{array}$ & $\begin{array}{l}\text { Insects (74\% } \\
\text { Hymenoptera) } \\
\text { (23); pollina- } \\
\text { tion neces- } \\
\text { sary for fruit } \\
\text { production } \\
\text { (23) } \\
1^{\prime} 700-1 ' 900 \\
\text { seeds/ shrub } \\
\text { (23) }\end{array}$ & $\begin{array}{l}\text { Viable seeds at } \\
\text { dispersal } \\
\text { represent only } 8 \% \\
\text { of the total } \\
\text { reproductive } \\
\text { potential }(23) \\
\text { Fruits/bush = } 205 \\
+66(\text { age of shrub } \\
-20)(32)\end{array}$ & $\begin{array}{l}\text { Spring and } \\
\text { early fall } \\
\text { (Mojave and } \\
\text { Sonoran)early } \\
\text { fall (Chihua- } \\
\text { huan) }(8,10) \\
\text { Within } 1 \\
\text { month (in } \\
\text { July) } 94 \% \text { of } \\
\text { seed were } \\
\text { dispersed } \\
\text { (after bloom } \\
\text { in May) (22) }\end{array}$ & $\begin{array}{l}\text { Wind, water } \\
\text { sheet wash, } \\
\text { strong winds, } \\
\text { caching of } \\
\text { seeds by } \\
\text { rodents (48) }\end{array}$ & $\begin{array}{l}3.5 \\
\mathrm{mg} / \mathrm{seed} \\
\text { (Sonoran), } \\
2.8 \\
\mathrm{mg} / \mathrm{seed} \\
\text { (Mojave), } \\
1.6 \mathrm{mg} / \\
\text { seed } \\
\text { (Chihua- } \\
\text { huan) (95) } \\
1.89 \mathrm{mg} / \\
\text { seed (32) }\end{array}$ & $\begin{array}{l}\text { Threshold } \\
\text { velocity for } \\
\text { wind: } 3.9 \\
\mathrm{~km} / \mathrm{h}(36)\end{array}$ \\
\hline
\end{tabular}

Simonin, K. A. (2000). U.S. Department of Agriculture, Forest Services, Rocky Mountain Research Station, FSL. http://www.fs.fed.uS/database/feis/
Uchytil, R. J. (1988). U.S. Department of Agriculture, Forest Services, Rocky Mountain Research Station, FSL. http://www.fs.fed.us/database/feis/

Korthuis, S. L. (1988). U.S. Department of Agriculture, Forest Services, Rocky Mountain Research Station, FSL. http://www.fs.fed.us/database/feis/

Steinberg, P. (2001). U.S. Department of Agriculture, Forest Services, Rocky Mountain Research Station, FSL. http://www.fs.fed.us/database/feis/

Marshall, K. A. (1995). Korthuis, S. L. (1988). U.S. Department of Agriculture, Forest Services, Rocky Mountain Research Station, FSL. http://www.fs.fed.us/database/feis/ 
Table B6. Recruitment characteristics.

\begin{tabular}{|c|c|c|c|c|c|c|c|c|c|}
\hline Abbrev. & $\begin{array}{c}\text { Minimum } \\
\text { water pot. for } \\
\text { germination }\end{array}$ & $\begin{array}{l}\text { Temp. range } \\
\text { for } \\
\text { germination }\end{array}$ & $\begin{array}{c}\text { Optimum } \\
\text { temp. for } \\
\text { germination }\end{array}$ & Sprouting? & $\begin{array}{c}\text { Seed bank } \\
\text { persistence }\end{array}$ & $\begin{array}{l}\text { Viability } \\
\text { of seeds }\end{array}$ & $\begin{array}{l}\text { Establishment } \\
\text { probability }\end{array}$ & Seedling biomass & $\begin{array}{c}\text { Root : Shoot } \\
\text { seedling biomass }\end{array}$ \\
\hline BOER & $\begin{array}{l}-1.0 \mathrm{Mpa} \\
(64)\end{array}$ & $\begin{array}{l}20-35^{\circ} \mathrm{C} \\
(64)\end{array}$ & & & & $\begin{array}{l}2 \%-41 \% \\
\text { germinated in } \\
\text { different years } \\
\text { (69) } \\
\text { No seeds were } \\
\text { found at the } \\
\text { Jornada } 1926 \\
\text { (52) }\end{array}$ & $\begin{array}{l}6.4 \text { seedlings/ } \\
\mathrm{m}^{2} / \mathrm{yr} \text { (Arizona) } \\
(31) \\
\text { Seedlings in } 7 \text { out } \\
\text { of } 54 \text { years }(68)\end{array}$ & 3.5 months old $30 \mathrm{~g}(16)$ & $\begin{array}{l}\text { Root: shoot of } 5 \text { months old } \\
\text { plants: } 1.2 \text { (38) } \\
5 \text { weeks after development } \\
\text { of secondary roots: } 0.4-0.6 \\
\text { (39) } \\
3.5 \text { months old } 0.17(16)\end{array}$ \\
\hline PLMU & & $\begin{array}{l}\text { up to } 53^{\circ} \mathrm{C}^{*} \\
\text { good under } \\
39^{\circ} \mathrm{C}(70)\end{array}$ & $39^{\circ} \mathrm{C}$ & Yes & & $\begin{array}{l}10 \%-40 \% \\
\text { (according to } \\
\text { medium) } \\
\text { germinated of } \\
\text { the seed crop } \\
\text { from } 1926 \text { (52) }\end{array}$ & & & $\begin{array}{l}5 \text { weeks after development } \\
\text { of secondary roots: } 0.4-0.8 \\
\text { (39) }\end{array}$ \\
\hline \multicolumn{10}{|l|}{ FLCE } \\
\hline PRGL & & $\begin{array}{l}21-38^{\circ} \mathrm{C} \\
(80)\end{array}$ & $\begin{array}{l}24- \\
27^{\circ} \mathrm{C}^{\dagger}(89) \\
29^{\circ} \mathrm{C}(80)\end{array}$ & $\begin{array}{l}\text { Yes, with } \\
\text { 3-5 years } \\
\text { lag if dry }\end{array}$ & $\begin{array}{l}\text { Seeds remained } \\
\text { viable for } 10 \\
\text { years in the soil } \\
(90) \\
42 \% \text { germinated } \\
\text { in the field } \\
\text { (Texas) (26) }\end{array}$ & & $\begin{array}{l}\text { Over } 17 \text { years } \\
\text { about } 1 \text { new tree } \\
\text { established in } \\
\text { every } 2 \mathrm{~m}^{2}(47)\end{array}$ & $\begin{array}{l}0.8 \mathrm{~g} \text { dry mass/plant in } \\
\text { one growing season (93) } \\
\text { Around } 0.5 \mathrm{~g} \text { in } 4 \text { months } \\
(74) \\
4 \text { months old } 20 \mathrm{~g}(16) \\
4 \text { months old } 1.41 \mathrm{~g} \mathrm{(5)} \\
0.84-2.42 \mathrm{~g} / \text { plant after } \\
60 \text { days according to soil } \\
\text { texture (27) }\end{array}$ & $\begin{array}{l}0.6 \mathrm{~g} \text { abg, } 0.2 \mathrm{~g} \text { blg (93) } \\
\text { Root:shoot of } 4 \text { months old } \\
\text { plants } 0.675 \text { ( } 74 \text { ) } \\
14 \text { weeks old } 0.4-0.6 \text { (60) } \\
4 \text { months old } 0.3 \text { (16) } \\
4 \text { months old } 1.07 \text { (up to } 50 \\
\text { cm depth for roots) (5) } \\
0.18-0.75 \text { according to soil } \\
\text { texture (27) }\end{array}$ \\
\hline LATR & $\begin{array}{l}\text { needs }>2.5 \\
\text { cm rain** } \\
\text { After heavy } \\
\text { rains (19) }\end{array}$ & \begin{tabular}{|l} 
Nighttime \\
temperature \\
$>20^{\circ} \mathrm{C}(10)$ \\
$20-33^{\circ} \mathrm{C}(8)$
\end{tabular} & $\begin{array}{l}23^{\circ} \mathrm{C}^{1}(8) \\
24.5^{\circ} \mathrm{C}(7) \\
\text { late } \\
\text { summer } \\
(22)\end{array}$ & \begin{tabular}{|l} 
Yes $^{1}$, \\
between \\
$33.3-$ \\
$100 \%$ of \\
plants re- \\
sprouted \\
after fire \\
$(17)$
\end{tabular} & $\begin{array}{l}\text { No viable } \\
\text { mericarps were } \\
\text { found } 10 \text { months } \\
\text { after dispersal } \\
\text { (22) } \\
\text { If stored at } 37^{\circ} \mathrm{C} \\
\text { for } 30 \text { days } \\
\text { germinability of } \\
\text { seeds } \\
\text { significantly } \\
\text { decreased } \\
\text { (Chihuahuan) } \\
\text { (7) }\end{array}$ & \begin{tabular}{|l}
$41 \%$ of \\
developed \\
seeds were \\
viable (23) \\
$51 \%$ \\
(Chihuahuan) \\
$37 \%$ (Sonoran) \\
$42 \%$ (Mojave) \\
$(7)$ \\
$45.4 \%(61)$ \\
$15-76 \%(8)$
\end{tabular} & $\begin{array}{l}\text { Low, especially in } \\
\text { dense grass cover } \\
\text { and creosote areas } \\
\text { (97) } \\
66 \% \text { of seedlings } \\
\text { (6 months in } \\
\text { greenhouse) }(7,8) \\
8,16 \text { seedlings } \\
\text { established }(335 \\
\mathrm{m}, 8 \text { yrs) }(18) \\
7 \% / 3 \% \text { over } 100 \\
\text { years }(24)\end{array}$ & $\begin{array}{l}1.31 \mathrm{~g}(3 \mathrm{mo} . \\
\text { seedling }(10)(12) \\
\text { After } 1-3 \text { years } 4.5-15 \\
\mathrm{~cm} \text { in height }(22) \\
4 \text { months old } 10 \mathrm{~g} \mathrm{(16)}\end{array}$ & $\begin{array}{l}0.19(0.22-1.08)(3 \mathrm{mo} . \\
\text { seedling }(10,12) \\
0.33-0.52(95) \\
4 \text { months old } 0.3(16) \\
0.5 \text { (Chihuahuan) }(7)\end{array}$ \\
\hline
\end{tabular}

* Uchytil, R. J. (1988). U.S. Department of Agriculture, Forest Services, Rocky Mountain Research Station, FSL. http://www.fs.fed.us/database/feis/

** Marshall, K. A. (1995). Korthuis, S. L. (1988). U.S. Department of Agriculture, Forest Services, Rocky Mountain Research Station, FSL. http://www.fs.fed.us/database/feis/ 
Table B7. Phenology and growth. Turnover rates of above-ground biomass and estimates of the amount of photosynthate needed for the maintenance of perennial biomass were not found in the literature. They have to be deduced from water use efficiency (WUE), respiration rates, and growth rates.

\begin{tabular}{|c|c|c|c|c|c|c|c|c|}
\hline Abbrev. & $\begin{array}{l}\text { Phen- } \\
\text { ology }\end{array}$ & $\begin{array}{l}\text { Optimum temp. for } \\
\text { growth }\end{array}$ & Flowering & \begin{tabular}{|l|} 
Photo- \\
synthetic \\
pathway
\end{tabular} & Deciduous? & Leafing out & Growth rate & WUE \\
\hline BOER & SU* & $33^{\circ} \mathrm{C}(21)$ & $\begin{array}{l}\text { August-September } \\
\text { (5-7 weeks after } \\
\text { summer rains) }{ }^{\dagger} \text { (69) } \\
\text { Eight weeks after } \\
\text { initiation of growth (43) } \\
\text { July-September (after } \\
\text { rainfall) (46) }\end{array}$ & C4 & $\begin{array}{l}\text { remains green over } \\
\text { winter }(43,73)\end{array}$ & $\begin{array}{l}\text { Late June/ early July } \\
\text { depending on rainfall (43) } \\
\text { First growth can be } \\
\text { observed in late April/May } \\
\text { if year is wet (54) }\end{array}$ & $\begin{array}{l}\text { Mean growth rate of } \\
\text { crowns ranged between }- \\
0.6-+1.4 \mathrm{~cm} / \text { year }(63)\end{array}$ & $\begin{array}{l}437.7 \mathrm{~g} \mathrm{H}_{2} \mathrm{O} / \mathrm{g} \\
\text { biomass }(38) \\
476437.7 \mathrm{~g} \mathrm{H}_{2} \mathrm{O} / \mathrm{g} \\
\text { biomass }(73)\end{array}$ \\
\hline PLMU & SU & $35^{\circ} \mathrm{C}(34)$ & & C4 & $\begin{array}{l}\text { keeps growing over } \\
\text { the winter if } \\
\text { conditions are mild**}\end{array}$ & & $4.73 \mathrm{~g} / \mathrm{m}^{2} /$ day (66) & $\begin{array}{l}\text { 439.1 } \mathrm{g} \mathrm{H}_{2} \mathrm{O} / \mathrm{g} \\
\text { biomass(38) }\end{array}$ \\
\hline FLCE & SU & & $\begin{array}{l}\text { late fall, fruits mature } \\
\text { Jan-March }^{\dagger \dagger}\end{array}$ & C3 & & & $\begin{array}{l}\text { Slow } \\
0.2 \mathrm{~mm} / \text { day (66) }\end{array}$ & \\
\hline PRGL & SP-SU* & $\begin{array}{l}29^{\circ} \mathrm{C} \text { soil temperature } \\
(60) \\
\text { Below } 32^{\circ} \mathrm{C}(57)\end{array}$ & $\begin{array}{l}\text { April-May } \star \star \star \\
\text { Follows the same } \\
\text { pattern as leaf } \\
\text { production, triggered by } \\
\text { photoperiod (91) }\end{array}$ & C3 & $\begin{array}{l}\text { loose leaves } \\
\text { November - } \\
\text { December } \\
\text { leave senescence in } \\
\text { September (71) } \\
\text { loses leaves when } \\
\text { temperature drop } \\
\text { below freezing (55) }\end{array}$ & $\begin{array}{l}\text { March-April, second cohort } \\
\text { in August (71) } \\
\text { Soil tempe-ratures }>18- \\
21^{\circ} \mathrm{C}(89) \\
\text { End of March, occasionally } \\
\text { after summer rains (91) } \\
\text { Budbreak mid-March - } \\
\text { mid April (Texas) (4) }\end{array}$ & $\begin{array}{l}0.1 \mathrm{~mm} / \text { day }(66) \\
\text { annual percentage } \\
\text { volume increase } 5.7 \% \\
(3)\end{array}$ & $\begin{array}{l}1,431.7 \mathrm{~g} \mathrm{H}_{2} \mathrm{O} / \mathrm{g} \\
\text { biomass(38) }\end{array}$ \\
\hline LATR & SP-SU ${ }^{1}$ & $\begin{array}{l}15^{\circ} \mathrm{C} \text {. Can be as high } \\
\text { as } 25^{\circ} \mathrm{C} \text { after } \\
\text { acclimation (88) } \\
\text { Photosynthesis is } \\
\text { virtually the same in } \\
\text { January and July (87) } \\
\text { Different T according } \\
\text { to season (67) }\end{array}$ & $\begin{array}{l}\text { after rain }^{\dagger \dagger} \\
\text { July-August (42) } \\
\text { spring and late summer } \\
\text { (Chihuahuan) (10) } \\
\text { after }>20 \mathrm{~mm} \text { rain and } \\
\text { a heat sum of about } 443 \\
\text { degree-days above } \\
10^{\circ} \mathrm{C}(20)\end{array}$ & $\begin{array}{l}\text { C3 (10, } \\
12)\end{array}$ & $\begin{array}{l}\text { Evergreen } \\
\text { Stops growth if } \\
\text { temperature is } \\
\text { below } 0^{\circ} \mathrm{C}(55) \\
\text { Leaves live } 1-2 \\
\text { years (10) }\end{array}$ & $\begin{array}{l}\text { Is able to 'green up' within } \\
10-20 \text { days after rainfall } \\
(53) \\
\text { Mainly in March-May and } \\
\text { August - October (40) } \\
\text { Spring after wet winter (19) }\end{array}$ & $\begin{array}{l}\text { Slow }^{3} \\
\text { Optimum growth rate: } 4.6 \\
\mathrm{~kg} \mathrm{ha}^{-1} \text { day }^{-1}(55) \\
\text { Seedlings: } 3 \% / \text { day (95) } \\
\text { Total abg growth/ leaf } \\
\text { biomass } 0.01-0.18 \text { (35) } \\
0.1 \text { mm/day (66) }\end{array}$ & $\begin{array}{l}1,628.9 \mathrm{~g} \mathrm{H}_{2} \mathrm{O} / \mathrm{g} \\
\text { biomass(38) } \\
0.3-1.5 \mathrm{mg} \mathrm{CO}_{2} / \mathrm{mg} \\
\mathrm{H}_{2} \mathrm{O}(10)\end{array}$ \\
\hline
\end{tabular}

* Jornada Species List, Jornada LTER program, http://jornada-www.nmsu.edu/

† Simonin, K. A. (2000). U.S. Department of Agriculture, Forest Services, Rocky Mountain Research Station, FSL. http://www.fs.fed.us/database/feis/

** Uchytil, R. J. (1988). U.S. Department of Agriculture, Forest Services, Rocky Mountain Research Station, FSL. http://www.fs.fed.us/database/feis/

${ }^{\dagger}$ Korthuis, S. L. (1988). U.S. Department of Agriculture, Forest Services, Rocky Mountain Research Station, FSL. http://www.fs.fed.us/database/feis/

*** Steinberg, P. (2001). U.S. Department of Agriculture, Forest Services, Rocky Mountain Research Station, FSL. http://www.fs.fed.us/database/feis/

${ }^{\dagger \dagger}$ Marshall, K. A. (1995). Korthuis, S. L. (1988). U.S. Department of Agriculture, Forest Services, Rocky Mountain Research Station, FSL. http://www.fs.fed.us/database/feis/ 


\section{Literature Cited}

1. Anderson, D.M. (1982) Seasonal grazing of semidesert tobosa rangeland in southern New Mexico. Proceedings of the National Conference on Grazing Management and Technology (D.D. Briske and M.M. Kothmann, ed.), Department of Range Sciences, Texas A\&M University, p. 137-142.

2. Anderson, D.M. (1988) Seasonal stocking of tobosa managed under continuous and rotation grazing. Journal of Range Management, 41:78-82

3. Andrews, S.A. (1988) Volume estimation and multi-purpose management of Prosopis velutina in southern Arizona. PhD Thesis, University of Arizona.

4. Ansley, R.J., P.W. Jacoby, and R.A. Hicks (1991) Leaf and whole plant transpiration in honey mesquite following severing of lateral roots. Journal of Range Management, 44: 577-83

5. Archer, S. (1990) Development and stability of grass/woody mosaics in a subtropical savanna parkland, Texas, U.S.A. Journal of Biogeography, 17: 453-462.

6. Baggs, J.E. (1997) The role of Bouteloua eriopoda in the community structure and ecosystem function of a semi-arid grassland. PhD Thesis, New Mexico State University.

7. Barbour, M.G. (1967) Ecoclinal patterns in the physiological ecology of a desert shrub, Larrea divaricata. PhD Thesis, Duke University.

8. Barbour, M.G. (1968) Germination requirements of the desert shrub Larrea divaricata. Ecology, 49: 915-923.

9. Barbour, M.G. (1969) Age and space distribution of the desert shrub Larrea divaricata. Ecology, 50: 679-685

10. Barbour, M.G., G. Cunningham, W.C. Oechel, and S.A. Bamberg (1977) Growth and development, form and function. In Creosotebush: Biology and Chemistry of Larrea in New World Deserts (T.J. Mabry, J.H. Hunziker, and D.R. DiFeo, Jr., ed.). Stroudsburg, Pennsylvania: Dowden, Hutchinson and Ross, Inc., p. 48-91.

11. Barbour, M.G., and D.V. Diaz (1973) Larrea plant communities on bajada and moisture gradients in the United States and Argentina. Vegetatio, 28: $335-352$

12. Barbour, M.G., D.V. Diaz, and R.W. Breidenbach (1974) Contributions to the biology of Larrea species. Ecology, 55: 1199-1215 
13. Barbour, M.G., J.A. MacMahon, S.A. Bamberg, and J.A. Ludwig (1977) The structure and distribution of Larrea communities. In Creosotebush: Biology and Chemistry of Larrea in New World Deserts (T.J. Mabry, J.H. Hunziker, and D.R. DiFeo, Jr., ed.). Stroudsburg, Pennsylvania: Dowden, Hutchinson and Ross, Inc., p. 227-276.

14. Barth, R.C., and J.O. Klemmedson (1982) Amount and distribution of dry matter, nitrogen, and organic carbon in soilplant systems of mesquite and palo verde. Journal of Range Management, 35: 412-418.

15. Barth, R.C. (1975) Spatial distribution of carbon and nitrogen in some desert shrub ecosystems. PhD Thesis, University of Arizona.

16. BassiriRad, H., J.F. Reynolds, R.A. Virginia, and M.H. Brunelle (1997) Growth and root $\mathrm{NO}_{3}{ }^{-}$and $\mathrm{PO}_{4}{ }^{3-}$ uptake capacity of three desert species in response to atmospheric $\mathrm{CO}_{2}$ enrichment. Australian Journal of Plant Physiology, 24: 353-358.

17. Bazzell, M.T. (1988) Postfire recovery of creosote bush scrub in the Mojave desert of Southern California. PhD Thesis, University of California.

18. Beatley, J.C. (1974) Effects of rainfall and temperature on the distribution and behavior of Larrea tridentata (creosote-bush) in the Mojave desert of Nevada. Ecology, 55: 245-261.

19. Beatley, J.C. (1974) Phenological events and their environmental triggers in Mojave desert ecosystems. Ecology, 55: 856-863.

20. Bowers, J.E., and M.A. Dimmitt (1994) Flowering phenology of six woody plants in the northern Sonoran Desert. Bulletin of the Torrey Botanical Club, 121: 215-229.

21. Bowman, W.D., and L. Turner (1993) Photosynthetic sensitivity to temperature in populations of two C4 Bouteloua (Poaceae) species native to different altitudes. American Journal of Botany, 80: 369-374.

22. Boyd, R.S., and G.D. Brum (1983) Postdispersal reproductive biology of a Mojave desert population of Larrea tridentata (Zygophyllaceae). American Midland Naturalist, 110: 25-36.

23. Boydn, R.S., and G.D. Brum (1983) Predispersal reproductive attrition in a Mojave desert population of Larrea tridentata (Zygophyllaceae). American Midland Naturalist, 110: 14-24.

24. Brock, J.H. (1986) Velvet mesquite seedling development in three Southwestern soils. Journal of Range Management, 39: 331-334. 
25. Brown, J.R., and S. Archer (1987) Woody plant seed dispersal and gap formation in a North American subtropical savanna woodland: The role of domestic herbivores. Vegetatio, 73: 73-80.

26. Brown, J.R., and S. Archer (1988) Establishment of mesquite in grasslands: Effects of herbaceous plant density, standing crop, and soil moisture enhancement. Rep. CPR-4592, College Station, TX

27. Buffington, L.C., and C.H. Herbel (1965) Vegetational changes on a semidesert grassland range from 1858 to 1963 . Ecological Monographs, 35 : 139-164.

28. Burk, J.H., and W.A. Dick-Peddie (1973) Comparative production of Larrea divaricata Cav. on three geomorphic surfaces in southern New Mexico. Ecology, 54: 1094-1102.

29. Bush, J.K., and O.W. Van Auken (1991) Importance of time of germination and soil depth on growth of Prosopis glandulosa (Leguminosae) seedlings in the presence of a C4 grass. American Journal of Botany, 78: 1732-1739.

30. Canfield, R.H. (1939) The effect of intensity and frequency of clipping on density and yield of black grama and tobosa grass. U.S. Dept. of Agriculture, Washington, D.C. 32 p.

31. Canfield, R.H. (1957) Reproduction and life span of some perennial grasses of southern Arizona. Journal of Range Management, 10: 199-203.

32. Chew, R.M., and A.E. Chew (1965) The primary productivity of a desert shrub (Larrea tridentata) community. Ecological Monographs, 35: 355-375.

33. Cross, A.F., and W.H. Schlesinger (1999) Plant regulation of soil nutrient distribution in the northern Chihuahuan desert. Plant Ecology, 145: 11-25.

34. Cunningham, G.L., F.R. Balding, and J.P. Syvertsen (1974) A net $\mathrm{CO}_{2}$ exchange model for C4-grasses. Photosynthetica, 8: 28-33.

35. Cunningham, G.L., J.P. Syvertsen, J.F. Reynolds, and J.M. Willson (1979) Some effects of soil-moisture availability on above-ground production and reproductive allocation in Larrea tridentata (DC) Cov. Oecologia, 40: 113-123.

36. de Soyza, A.G., W.G. Whitford, E. Martinez-Meza, and J.W. Van Zee (1997) Variation in creosotebush (Larrea tridentata) canopy morphology in relation to habitat, soil fertility and associated annual plant communities. American Midland Naturalist, 137: 13-25. 
37. Dwyer, D.D. (1972) Burning and nitrogen fertilization of tobosa grass. Bulletin No. 595, New Mexico Agricultural Experiment Station.

38. Dwyer, D.D., and H.C. DeGarmo (1970) Greenhouse productivity and water-use efficiency of selected desert shrubs and grasses under four soilmoisture levels. Bulletin No. 570, New Mexico Agricultural Experiment Station.

39. Fernández, R.J., and J.F. Reynolds (2000) Potential growth and drought tolerance of eight desert grasses: Lack of a trade-off? Oecologia, 123: 90-98.

40. Fisher, F.M., J.C. Zak, G.L. Cunningham, and W.G. Whitford (1988) Water and nitrogen effects on growth and allocation patterns of creosotebush in the northern Chihuahuan Desert. Journal of Range Management, 41: 387391.

41. Fonteyn, P.J., and B.E. Mahall (1981) An experimental analysis of structure in a desert plant community. Journal of Ecology, 69: 883-896.

42. Franco, A.C., A.G. de Soyza, R.A. Virginia, J.F. Reynolds, and W.G. Whitford (1994) Effects of plant size and water relations on gas exchange and growth of the desert shrub Larrea tridentata. Oecologia, 97: 171-178.

43. Gadzia, K.L. (1979) Growth and development patterns of black grama in southern New Mexico. PhD Thesis, New Mexico State University.

44. Garcia-Moya, E., and C.M. McKell (1970) Contribution of shrubs to the nitrogen economy of a desert-wash plant community. Ecology, 51: 81-88.

45. Gibbens, R.P., and J.M. Lenz (2001) Root systems of some Chihuahuan desert plants. Journal of Arid Environments, 49: 221-263.

46. Gibbens, R.P. (1989) Phenology of native and introduced grasses in southern New Mexico. Abstract No. 061, 42nd Annual Meeting of the Society of Range Management.

47. Glendening, G.E. (1952) Some quantitative data on the increase of mesquite and cactus on a desert grassland range in southern Arizona. Ecology, 33: 319-328.

48. Grover, H.D., and H.B. Musick (1990) Shrubland encroachment in southern New Mexico, USA. An analysis of desertification processes in the American Southwest. Climatic Change, 17: 305-330.

49. Hamerlynck, E.P., J.R. McAuliffe, E.V. McDonald, and S.D. Smith (2002) Ecological responses of two Mojave desert shrubs to soil horizon development and soil water dynamics. Ecology, 83: 768-779. 
50. Heitschmidt, R.K., R.J. Ansley, S.L. Dowhower, P.W. Jacoby, and D.L. Price (1988) Some observations from the excavation of honey mesquite root systems. Journal of Range Management, 41: 227-231.

51. Herbel, C.H. (1963) Fertilizing tobosa on flood plains in the semidesert grassland. Journal of Range Management, 16: 133-138.

52. Jackson, C.V. (1928) Seed germination in certain New Mexico range grasses. Botanical Gazette, 86: 270-294.

53. Johnson, H.B., F.C. Vasek, and T. Yonkers (1978) Residual effects of summer irrigation on Mojave desert annuals. Bulletin of the Southern California Academy of Science, 77: 95-108.

54. Kemp, P.R. (1983) Phenological patterns of Chihuahuan desert plants in relation to the timing of water availability. Journal of Ecology, 71: 427-43.

55. Ludwig, J.A., and W.G. Whitford (1981) Short-term water and energy flow in arid ecosystems. In Arid Land Ecosystems: Structure, Function and Management (D.W. Goodall and RA Perry, ed., with the assistance of K.M.W. Howes). Great Britain: Cambridge University Press, p. 271-299.

56. Ludwig, J.A., J.F. Reynolds, and P.D. Whitson (1975) Size-biomass relations of several Chihuahuan Desert shrubs. The American Midland Naturalist, 94: 451-461.

57. Maynard, M.L. (1970) Some effects of heat on the physiology of mesquite (Prosopis juliflora). PhD Thesis, University of Arizona.

58. McAuliffe, J.R. (1988) Markovian dynamics of simple and complex desert plant communities. American Naturalist, 131: 459-490.

59. McAuliffe, J.R. (1994) Landscape evolution, soil formation, and ecological patterns and processes in Sonoran desert bajadas. Ecological Monographs, 64: 111-148.

60. Meyer, R.E., R.H. Haas, and C.W. Wendt (1973) Interaction of environmental variables on growth and development of honey mesquite. Botanical Gazette, 134: 173-178

61. Miller, R.E., and L.F. Huenneke (2000) Demographic variation in a desert shrub, Larrea tridentata, in response to a thinning treatment. Journal of Arid Environments, 45: 315-323.

62. Miller, R.E., and L.F. Huenneke (2000) The relationship between density and demographic variation within a population of Larrea tridentata. The Southwestern Naturalist, 45: 313-321. 
63. Miller, R.F., and G.B. Donart (1979) Response of Bouteloua eriopoda (Torr.) Torr. and Sporobolus flexuosus (Thurb.) Rybd. to season of defoliation. Journal of Range Management, 32: 63-67.

64. Minnick, T.J., and D.P. Coffin (1999) Geographic patterns of simulated establishment of two Bouteloua species: Implications for distributions of dominants and ecotones. Journal of Vegetation Science, 10: 343-356.

65. Molinar, F., J. Holechek, D. Galt, and M. Thomas (2002) Soil depth effects on Chihuahuan desert vegetation. Western North American Naturalist, 62: 300-306.

66. Montańa, C., B. Cavagnaro, and O. Briones (1995) Soil water use by coexisting shrubs and grasses in the southern Chihuahuan Desert, Mexico. Journal of Arid Environments, 31: 1-13.

67. Mooney, H.A., O. Björkman, and G.J. Collatz (1978) Photosynthetic acclimation of temperature in the desert shrub, Larrea divaricata. Plant Physiology, 61: 406-410.

68. Neilson, R.P. (1986) High-resolution climatic analysis and Southwest biogeography. Science, 232: 27-34.

69. Nelson, E.W. (1934) The influence of precipitation and grazing upon black grama grass range. Technical bulletin no. 409, U.S. Dept. of Agriculture, p. $1-32$.

70. Neuenschwander, L.H., S.H. Sharrow, and H.A. Wright (1975) Review of Tobosa grass (Hilaria mutica). Southwestern Naturalist, 20: 255-263.

71. Nilsen, E.T., M.R. Sharifi, P.W. Rundel, W.M. Jarrell, and R.A. Virginia (1983) Diurnal and seasonal water relations of the desert phreatophyte Prosopis glandulosa (honey mesquite) in the Sonoran desert of California. Ecology, 64: 1381-1393.

72. Olmsted, C.E. (1943) Growth and development in range grasses. III. Photoperiodic response in the genus Bouteloua. Botanical Gazette, 105: 165181.

73. Paulsen, H.A., Jr., and F.N. Ares (1962) Grazing values and management of black grama and tobosa grasslands and associated shrub ranges of the Southwest. U.S. Dept. of Agriculture, Forest Service, Washington. D.C. 56 p.

74. Perkins, S.R., and M.K. Owens (2003) Growth and biomass allocation of shrub and grass seedlings in response to predicted changes in precipitation seasonality. Plant Ecology, 168: 107-120. 
75. Peters, D.P.C. (2002) Plant species dominance at a grassland-shrubland ecotone: An individual-based gap dynamics model of herbaceous and woody species. Ecological Modelling, 152: 5-32.

76. Reynold, J.F. (1986) Adaptive strategies of desert shrubs with special reference to the creosotebush (Larrea tridentata [DC] Cov.). In Pattern and Process in Desert Ecosystems (W.G. Whitford, ed.). Albuquerque, New Mexico: University of New Mexico Press, p. 19-49.

77. Rogers, K.E. (2000) The Magnificent Mesquite. Austin, Texas: University of Texas Press. The Corrie Herring Hooks series.

78. Rundel, P.W., and P.S. Nobel (1991) Stucture and function in desert root systems. In Plant Root Growth: An Ecological Perspective (D. Atkinson, ed.). London, UK: Blackwell Scientific Publications, p. 349-378.

79. Schlesinger, W.H., and A.M. Pilmanis (1998) Plant-soil interactions in deserts. Biogeochemistry, 42: 169-187.

80. Scifres, C.J., and J.H. Brock (1969) Moisture-temperature interrelations in germination and early seedling development of honey mesquite. Journal of Range Management, 22: 334-337.

81. Sharifi, M.R., E.T. Nilsen, and P.W. Rundel (1982) Biomass and net primary production of Prosopis glandulosa (Fabaceae) in the Sonoran Desert of California. American Journal of Botany, 69: 760-767.

82. Simpson, B.B. (1977) Mesquite, Its Biology in Two Desert Scrub Ecosystems. Stroudsburg, Pa.: Dowden, Hutchinson and Ross; exclusively distributed by Halsted Press. 250 p.

83. Smith, S.D., R.K. Monson, and J.E. Anderson (1997) Physiological Ecology of North American Desert Plants. Berlin: Springer. 275 p.

84. Smith, S.E., M.R. Haferkamp, and P.W. Voigt (In press) Grama grasses. In Warm Season Grasses (B. Burson, ed.). Madison, WI: Crop Science Society of America, p. 1-46.

85. Stephens, G., and W.G. Whitford (1993) Responses of Bouteloua eriopoda to irrigation and nitrogen fertilization in a Chihuahuan Desert grassland. Journal of Arid Environments, 24: 415-421.

86. Stephens, G.A. (1989) Response of black grama grass, Bouteloua eriopoda, to water and nitrogen in a northern Chihuahuan Desert grassland. PhD Thesis, New Mexico State University.

87. Strain, B.R. (1969) Seasonal adaptations in photosynthesis and respiration in four desert shrubs growing in situ. Ecology, 50: 511-513. 
88. Strain, B.R., and V.C. Chase (1966) Effect of past and prevailing temperatures on the carbon dioxide exchange capacities of some woody desert perennials. Ecology, 47: 1043-1045.

89. Texas Agricultural Experiment Station (1974) Mesquite: Growth and Development, Management, Economics, Control, Uses. College Station, Texas: Texas Agricultural Experiment Station.

90. Tschirley, F.H., and S.C. Martin (1960) Germination and longevity of velvet mesquite seed in the soil. Journal of Range Management, 13: 94-97.

91. Turner, R.M. (1963) Growth in four species of Sonoran desert trees. Ecology, 44: 760-765.

92. Valentine, K.A., and J.B. Gerard (1969) Life-history characteristics of the creosotebush, Larrea tridentata. Bulletin No. 526, New Mexico Agricultural Experiment Station, p. 1-32.

93. Van Auken, O.W., and J.K. Bush (1997) Growth of Prosopis glandulosa in response to changes in aboveground and belowground interference. Ecology, 78: $1222-1229$.

94. Vasek, F.C. (1980) Creosote bush: Long-lived clones in the Mojave desert. American Journal of Botany, 67: 246-255.

95. Walters, J.P., and E.C. Freeman (1983) Growth rates and root:shoot ratios in seedlings of the desert shrub Larrea tridentata. Southwestern Naturalist, 28: $357-363$.

96. Warren, A., J. Holechek, and M. Cardenas (1996) Honey mesquite influences on Chihuahuan Desert vegetation. Journal of Range Management, 49: 46-52.

97. Whitford, W.G., R. Nielson, and A. de Soyza (2001) Establishment and effects of establishment of creosotebush, Larrea tridentata, on a Chihuahuan Desert watershed. Journal of Arid Environments, 47: 1-10.

98. Wright, R.G., and G.M. Van Dyne (1981) Population age structure and its relationship to the maintenance of a semidesert grassland undergoing invasion by mesquite. The Southwestern Naturalist, 26: 13-22. 


\section{APPENDIX C. DESCRIPTION OF SOILWAT}

This description is based on code (stand-alone version 1996) and Parton (1978).

\section{Introduction}

SOILWAT is essentially what was called the water-flow submodel of the ELM model, which was a grassland simulation model for the shortgrass steppe in northern Colorado. It is a tipping-bucket soilwater model (Fig. C1). The vegetation parameters are community-level input, including total standing live and dead biomass $/ \mathrm{m}^{2}$, litter, biomass-to-leaf-area conversion factor, and root distribution. The soil characteristics are soil texture and water content at field capacity and at the wilting point.

The processes simulated on a daily time step are interception, percolation of water through the soil (by fast and by slow drainage), evaporation of intercepted water, bare-soil evaporation, and transpiration. Actual evapotranspiration is calculated based on potential evapotranspiration (according to Penman's equation) and water potential in each soil layer. Actual evapotranspiration is partitioned between transpiration and bare-soil evaporation based on active leaf area. Transpiration is a function of active leaf area; it occurs from all soil layers where there are roots present. Bare-soil evaporation can occur from the upper soil layers as specified by the user (i.e. the depth of bare-soil evaporation can be varied).

SOILWAT has been used for a long time for numerous simulation tasks, in particular a number of studies on germination and establishment probabilities of blue grama and black grama (Sala et al. 1992; Lauenroth et al. 1994; Minnick and Coffin 1999; Peters 2000).

\section{Detailed description of processes}

The stand-alone version from 1996 shows slight differences from the original publication of the model in 1978 (Parton 1978). In what follows the stand-alone version is described. For literature citations, see Parton (1978).

\section{Interception}

Interception is a function of precipitation and vegetation cover $(=$ interception by the standing biomass) or the amount of litter (= litter interception). The equations are based on Corbett and Crouse (1968), who predicted interception for an annual grassland. 


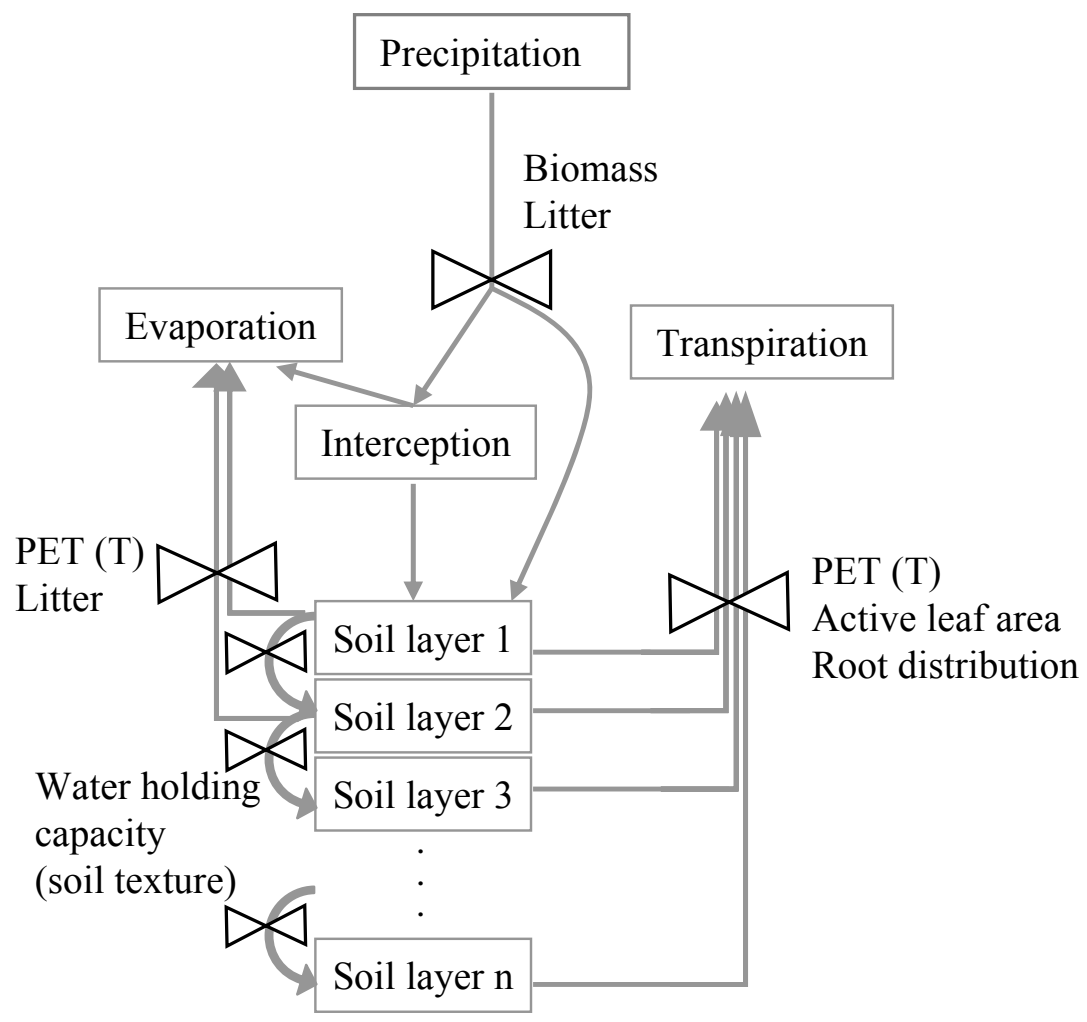

Figure C1. Flow diagram of SOILWAT.

It is calculated in the following way:

Interception by the standing biomass (live and dead):

wintstcr $=\operatorname{par} 1 * 0.026 * \mathrm{ppt}+0.094 *$ par2

if $($ wintstcr $>$ ppt $)$ then wintstcr $=p p t$

where $\mathrm{ppt}=$ precipitation and melted snow of the day

parl: if $(\operatorname{vegcov}<8.5)$ then parl $=0.9+0.04 *$ vegcov

else par1 $=1.24+(\operatorname{vegcov}-8.5) * 0.35$

par2: if $(\operatorname{vegcov}<3.0)$ then par2 $=$ vegcov $* 0.333$

else par2 $=1+(\operatorname{vegcov}-3.0) * 0.182$

where vegcov $($ month $)=$ pctcover $($ month $) *$ canopyht $($ month $)$

where pctcover $($ month $)=$ percent cover $=$ biomass $/$ convlai $/ 3$

where biomass $=$ standing live and dead biomass of the month

convlai $($ month $)=$ monthly amount of biomass needed to produce an

LAI of 1 , usually convlai $=195.5$ (for arid systems)

canopyht $($ month $)=12+(34 / 3.14159) *$

$\operatorname{atan}(3.14159 * 0.002 *($ biomass -300$))$

based on Conant (1972). 
Litter interception:

wintlit(NDAY) $=(0.015 *$ pptleft +0.0635$) * \exp (\operatorname{par} 1)$

where par $1=\left(-1+0.45^{*}\right.$ alog $10($ blitter $($ month $\left.)+1)\right) * \operatorname{alog}(10)$

and pptleft $=p p t-$ wintstcr (i.e. precipitation left from precipitation after

standing biomass interception)

blitter(month $)=$ biomass of the litter for the current month.

\section{Water percolation in the soil}

The water is moved down through the soil according to the principle of a tipping bucket, i.e. each layer of the soil is conceptualized as a bucket, which can hold only the amount of water that can be held at field capacity. Any water flowing into the layer in excess of that amount is moved to the next deeper layer on a daily time step (fast drainage). The water remaining in layers is then slowly percolating into the next deeper layer (slow drainage). Upward flow of the water occurs only through transpiration and evaporation. Each layer maintains a minimum soilwater content. If water flow beyond the deepest layer is allowed, deep drainage occurs; otherwise, water is accumulating in the deepest layer.

Slow drainage is a function of the difference between the current water content of the soil layer and the water content at field capacity, according to the following equation:

Slow drainage $=\operatorname{sdrainpar} * \exp ((\operatorname{swc}(\operatorname{lyr})-\operatorname{swcfc}(\operatorname{lyr})) * 40 /$ width $(l y r))$

where sdrainpar $=$ slow drainage coefficient (usually 0.06 )

$$
\begin{aligned}
\operatorname{swc}(\operatorname{lyr}) & =\text { actual soilwater content of the layer } \\
\operatorname{swcfc}(\operatorname{lyr}) & =\text { soilwater content the layer can hold at field capacity } \\
\operatorname{width}(\mathrm{lyr}) & =\text { width of the layer. }
\end{aligned}
$$

\section{Water retention curve}

For the calculation of evaporation and transpiration soil water potential is used. Based on the soil water content and the texture, this is calculated according to a fitted power function from Cosby et al. (1984):

$$
\text { swpotent }=(\operatorname{psis}(\mathrm{lyr}) /(\text { theta } / \text { thetas }(\text { lyr })) * * b / 1024
$$

where theta $=$ soilwater content (in percent volume) to be converted 


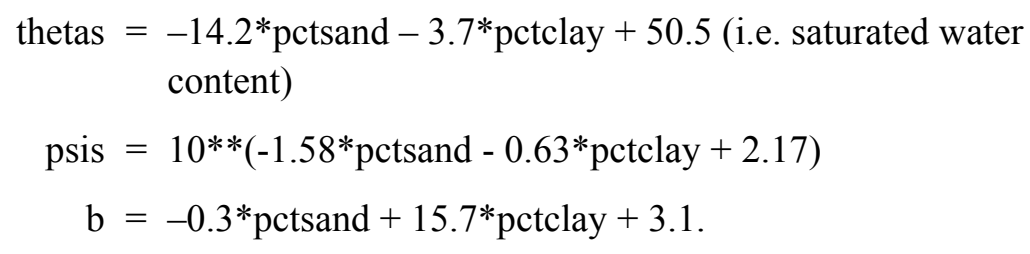

Potential evapotranspiration (PET)

Potential evapotranspiration depends on monthly input, except for temperature, which varies daily. Latitude and albedo (fraction of light reflected by the vegetation) vary only between sites for which the model is used. It is calculated using Penman's equation:

$$
\begin{gathered}
\text { petfunc }=((\operatorname{arads} * \text { parA }+0.27 * \text { parB }) /(\operatorname{arads}+0.27)) / 10 . \\
\text { if }(\text { petfunc }<0.01) \text { then petfunc }=0.01
\end{gathered}
$$

where

$$
\begin{aligned}
& \text { parA }=0.35 *(\text { svapor }(\text { avgtemp }(\text { jday }))-\text { fhumid }) *(1 .+0.0098 * \\
& \text { (windsp (month) *24. )) } \\
& \text { parB }=\operatorname{shwave}^{*}(1-\text { reflec }) *\left(0.18+0.55^{*} \text { clrsky }\right)-\text { ftemp* }(0.56- \\
& 0.092 * \operatorname{sqrt}(\text { fhumid }) *(0.10+0.90 * \text { clrsky }) \\
& \text { arads }=\text { svapor }(\operatorname{avgtemp}(\text { jday }))^{*} 3010.21 /(\text { kelvin } * \text { kelvin }) \\
& \text { svapor }=\text { saturated vapor pressure for the average temperature of the } \\
& \text { day [calculated using the Clausius-Clapeyron equation (Hess } \\
& \text { 1959)] } \\
& \text { kelvin }=\text { avgtemp }(\text { jday })+273 \text { (i.e. average temperature of the day in } \\
& \text { kelvins) } \\
& \text { windsp }=\text { average wind speed of the month (user input) } \\
& \text { clrsk }=\text { fraction clear sky based on the } \% \text { cloud cover for the month } \\
& \text { shwave }=\text { short-wave solar radiation on a clear day according to Sellers } \\
& \text { (1965) (Inputs: monthly light transmission, Julian day, the } \\
& \text { latitude of the site) }
\end{aligned}
$$




\section{Evaporation}

First, intercepted water (by the canopy and litter) is evaporated. If PET is bigger than the amount of water intercepted, all of it evaporates. PET is then reduced by the amount of water evaporated from interception. This constitutes atmospheric demand for total transpiration and bare-soil evaporation.

Second, bare-soil evaporation is calculated as a function of atmospheric demand, the inverse of the soil water potential in layers from which it can occur, the total biomass (including litter), and the active leaf area. The calculation involves determining the total amount of water lost from the soil through evaporation and partitioning this total amount amongst soil layers from which it is evaporating:

Total bare soil evaporation loss

$$
\begin{gathered}
\text { bserate }=0.5+(1.1 / 3.14159) * \operatorname{atan}(3.14159 * 0.06 *(\operatorname{par} 2- \\
\text { par1 }))^{*} \text { pet }(\text { jday }) * \text { shadeef*fbse }
\end{gathered}
$$

where $\quad$ if $($ pet $($ jday $)<0.2)$ parl $=3.0$

$$
\begin{aligned}
& \text { if }(\operatorname{pet}(\text { jday })<0.4) \operatorname{par} 1=(0.4-\operatorname{pet}(\text { jday })) *(-10)+5 \\
& \text { if }(\operatorname{pet}(\text { jday })<0.6) \operatorname{par} 1=(0.6-\operatorname{pet}(\text { jday })) *(-15)+8 \\
& \text { if }(\operatorname{pet}(\text { day })>=0.6) \operatorname{par} 1=8 \\
& \text { par2 }=15-\text { avswp } \\
& \text { avswp }=\text { average soil water potential over all layers } \\
& =\sum(\mathrm{i}=1, \text { nelyrs }) \text { width(i)*ecoeff(i)*swpotent/sumecoeff } \\
& \text { swpotent }=\text { soilwater potential } \\
& \text { ecoeff(i) = evaporation coefficient for the current soil layer } \\
& \text { width(i) }=\text { width of the current soil layer } \\
& \text { sumecoeff }=\text { sum of all the evaporation coefficients } \\
& \operatorname{pet}(\text { jday })=\text { potential evapotranspiration of the day } \\
& \text { shadeef }=(1-(\text { totagb/999) })(\text { effect of shading by the above-ground } \\
& \text { biomass) } \\
& \text { totagb }=\text { total above-ground biomass, i.e. the sum of the standing live } \\
& \text { and dead biomass plus the biomass of the litter, if } \\
& \text { (totagb }>999) \text { bserate }=0 \\
& \text { fbse }=\text { fraction of water loss from bare soil evaporation }
\end{aligned}
$$




$$
\begin{aligned}
\text { fbse } & =\exp (- \text { blivelai*1 })+0, \text { if }(\text { fbse }>0.995) \text { fbse }=0.995 \\
\text { blivelai } & =\text { active leaf area. }
\end{aligned}
$$

This evaporation loss is then adjusted so that is does not exceed the atmospheric demand.

\section{Actual evaporation from each soil layer}

evap $=(\operatorname{swpfrac}(\mathrm{lyr}) / \text { sumswp })^{*}$ bserate

where swpfrac(lyr) $=$ ecoeff(lyr $) /$ swpotent

$$
\begin{aligned}
\text { ecoeff(lyr }) & =\text { evaporation coefficient for the current soil layer } \\
\text { swpotent } & =\text { soilwater potential } \\
\text { sumswp } & =\sum(\mathrm{i}=1, \text { numlyrs }) \text { swpfrac(lyr) } \\
\text { bserate } & =\text { total evaporation loss as described above. }
\end{aligned}
$$

\section{Transpiration}

Transpiration depends on soil texture, the amount of water in the soil, the evaporative demand (PET), and a number of vegetation characteristics. The calculation of transpiration is analogous to the calculation of evaporation: first, the total transpiration loss is determined as a function of PET, the inverse of soil water potential in different soil layers, root distribution, and the active leaf area. Second, the transpiration is partitioned by layer. Both the amount of roots in each soil layer and the active leaf area are given as a percentage (0-1).

\section{Total transpiration loss}

$$
\begin{gathered}
\text { bstrate }=0.5+(1.1 / 3.14159) * \operatorname{atan}(3.14159 * 0.07 *(\text { par2 }- \\
\text { par1 })) * \text { PET }(\text { jday }) * \text { fbst }
\end{gathered}
$$

where

$$
\begin{aligned}
& \text { if }(\operatorname{PET}(\text { jday })<0.2) \text { par } 1=3.0 \\
& \text { if }(\operatorname{PET}(\text { jday })<0.4) \text { par } 1=(0.4-\operatorname{PET}(\text { jday }))^{*}(-10)+5 \\
& \text { if }(\operatorname{PET}(\text { jday })<0.6) \operatorname{par} 1=(0.6-\operatorname{PET}(\text { jday }))^{*}(-15)+8 \\
& \text { if }(\operatorname{PET}(\text { jday })>=0.6) \operatorname{par} 1=8 \\
& \operatorname{par} 2=28-\operatorname{swpavg} \\
& \text { swpavg }=\min (\text { trwtavg }(\text { iregion }))
\end{aligned}
$$




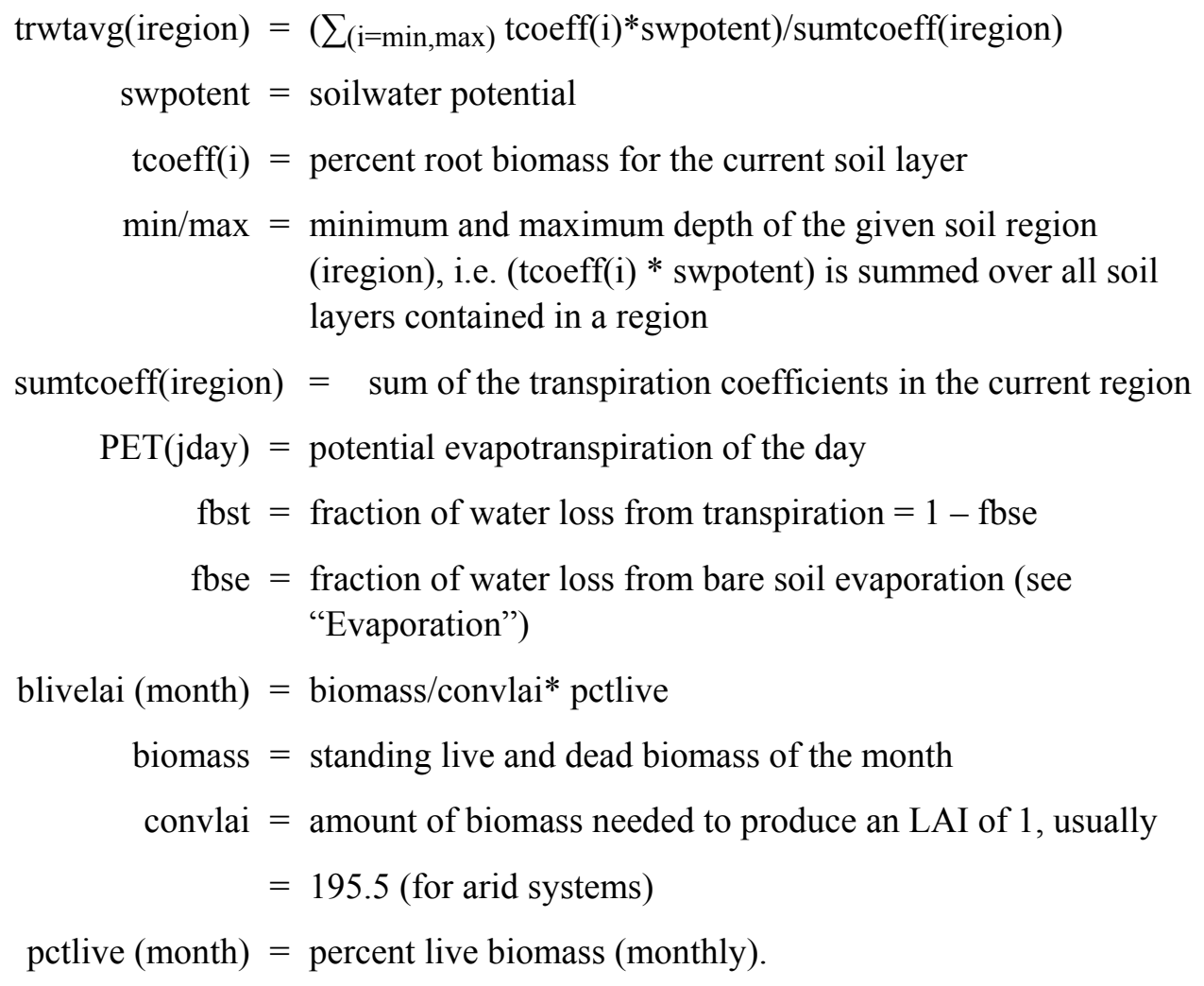

Actual transpiration from each soil layer

trans $=(\operatorname{swpfrac}($ lyr $) /$ sumswp $) *$ bstrate

where swpfrac $($ lyr $)=$ tcoeff(lyr)/swpotent

tcoeff(lyr $)=$ percentage of roots in the current soil layer

swpotent $=$ soilwater potential

bstrate $=$ total transpiration loss as described above

sumswp $=\sum(\mathrm{i}=1$, numlyrs $) \operatorname{swpfrac}(1 \mathrm{yr})$. 


\section{References}

Corbett, E.S. and R.P. Crouse (1968) Rainfall interception by annual grass and Chapparal. USDA Forest Ser. Res. Pap. PSW-48

Cosby, B.J., R.B. Clapp, G.M. Hornberger, and T.R. Ginn (1984) A Statistical exploration into the relationships of soil moisture characteristics to the physical properties of soils. Water Resources Research, 20(6): 682-690.

Hess, S. L., 1959: Introduction to Theoretical Meteorology. New York:Holt, Rhinehart and Winston, $362 \mathrm{pp}$.

Lauenroth, W.K., O.E. Sala, D.P. Coffin, and T.B. Kirchner (1994) The importance of soil water in the recruitment of Bouteloua gracilis in the shortgrass steppe. Ecological Applications, 4: 741-749.

Minnick, T.J., and D.P. Coffin (1999) Geographic patterns of simulated establishment of two Bouteloua species: Implications for distributions of dominants and ecotones. Journal of Vegetation Science, 10 (3): 343-356.

Parton, W.J. (1978) Abiotic section of ELM. In Grassland Simulation Model (G.S. Innis, ed.). New York: Springer Verlag, p. 31-53.

Peters, D.P.C. (2000) Climatic variation and simulated patterns in seedling establishment of two dominant grasses at a semi-arid-arid grassland ecotone. Journal of Vegetation Science, 11: 493-504.

Sala, O.E., W.K. Lauenroth, and W.J. Parton (1992) Long-term soil water dynamics in the shortgrass steppe. Ecology, 73: 1175-1181.

Sellers, W. D. (1965) Physical Climatology, University of Chicago Press. 


\section{APPENDIX D. TRAMPLING DISTURBANCE ROUTINE DEVELOPED FOR ECOTONE}

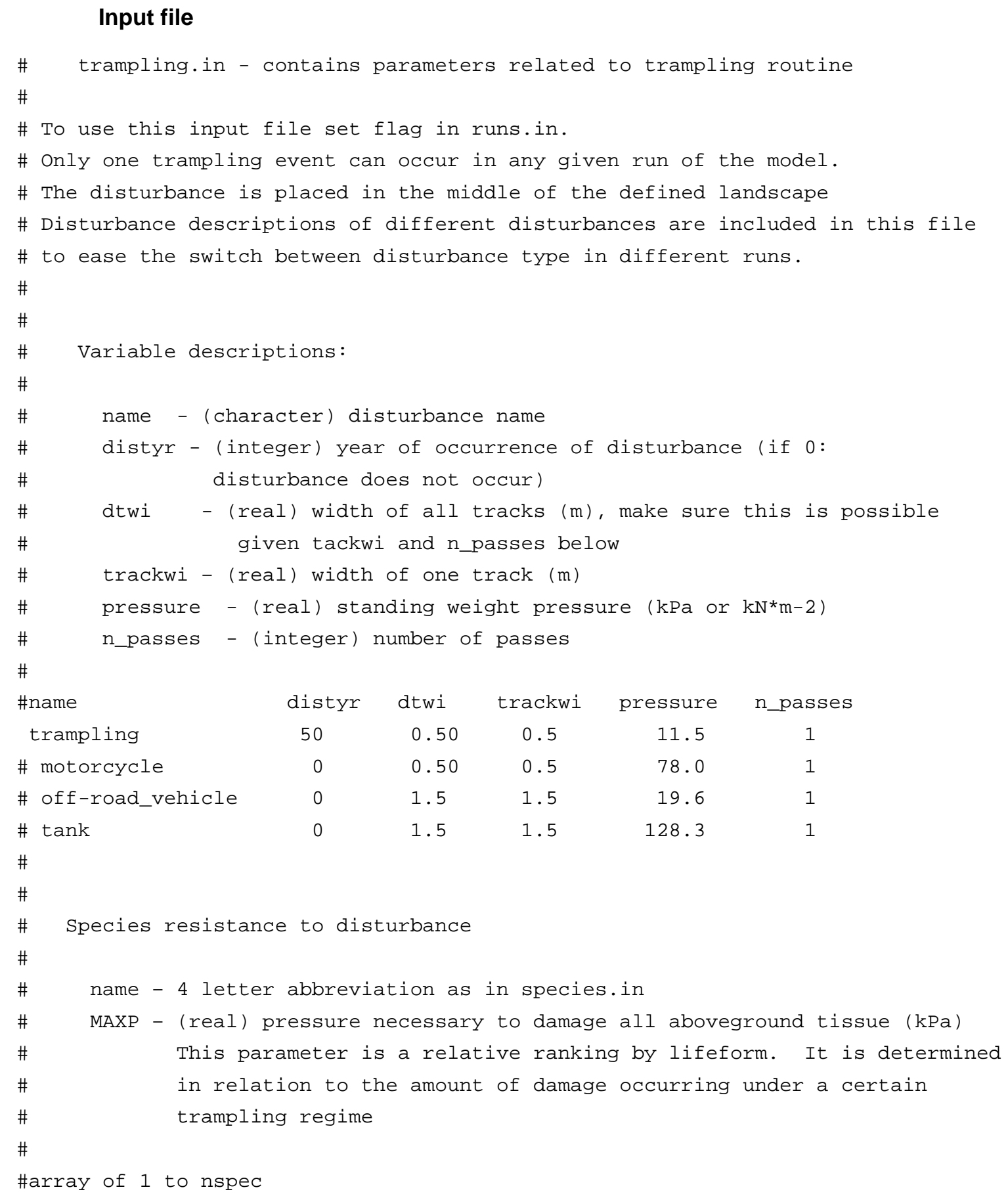




$\begin{array}{cc}\text { \# } & \text { MAXP } \\ \text { bogr } & 250 . \\ \text { boer } & 200 . \\ \text { arlo } & 250 . \\ \text { spcr } & 250 . \\ \text { stco } & 250 . \\ \text { latr } & 150 . \\ \text { gusa } & 100 . \\ \text { wpfb } & 100 . \\ \text { wafb } & 100 . \\ \text { wags } & 100 .\end{array}$

\section{Description of the disturbance routine}

In a user-defined year, the disturbance routine places a track of the desired width across the middle of the simulated landscape (Fig. D1a). More than one passage of a person or a vehicle can occur. By defining the disturbance width, the user can define if additional passages (after the first one) will occur on the same track as the first passage or immediately adjacent to it. Subsequent passages will all be adjacent to each other until the disturbance width is filled (Fig. D1b). In the latter case the area in the middle will be disturbed a second time, until all passages have been placed in the landscape (Fig. D1c).

Each disturbance agent will exert a certain weight, calculated according to its weight and the size of its "footprint." This weight is compared to the weight that the plant can withstand, and the biomass is reduced according to the following function (Fig. D2):

$$
\% \text { biomass reduction above ground }=\text { Pressure exerted } / \text { Maxpressure }
$$

If Pressure exerted/Maxpressure $<0.5$, then $\%$ biomass reduction below ground $=0$.

Otherwise $\%$ biomass reduction below ground $=2 *$ Pressure exerted/Maxpressure -1 .

This gives plants with a higher root:shoot ratio an advantage over plants with a lower root:shoot ratio, when the disturbance occurs.

All the plants on the plot are disturbed, but the effect varies between species according the pressure they can withstand. 


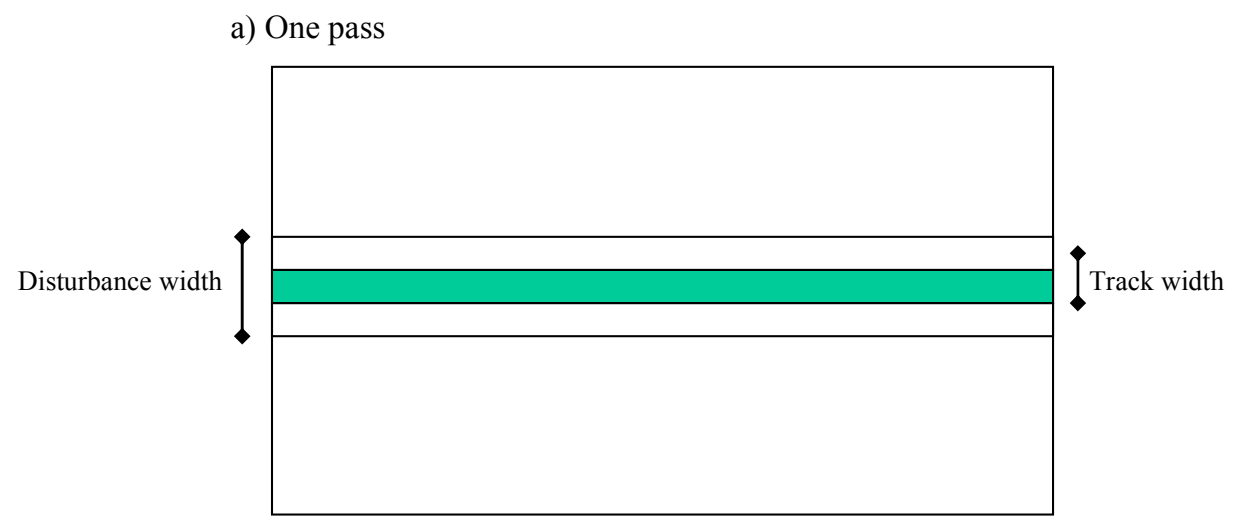

b) Three passes

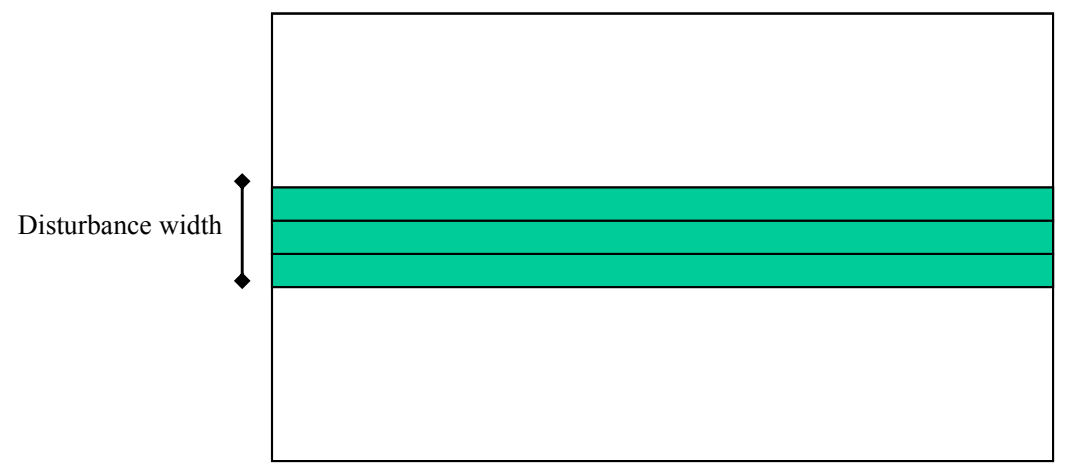

c) Four passes

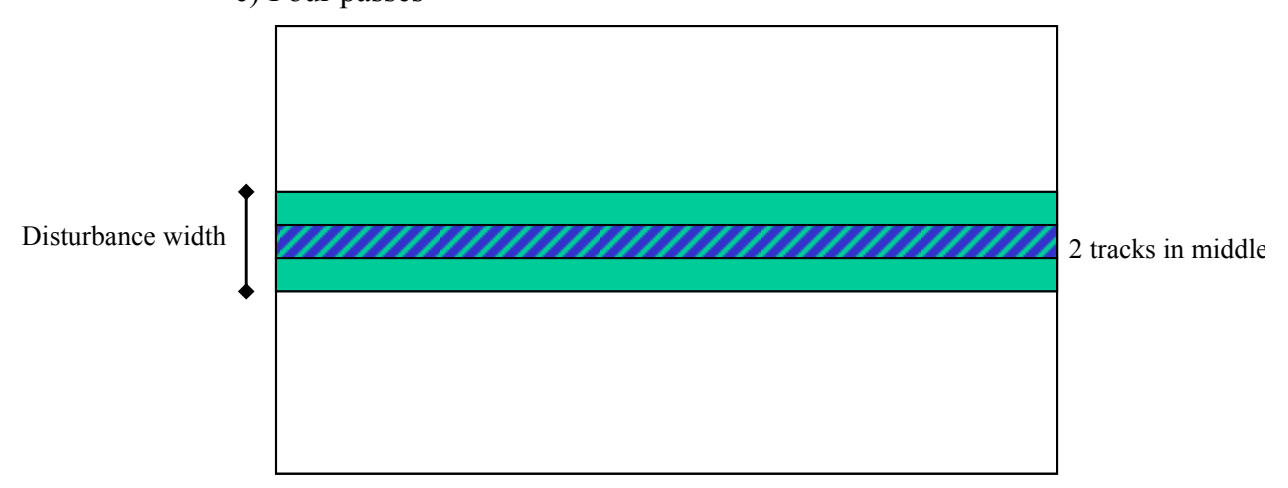

Figure D!. Distribution of tracks in landscape as simulated by trampling disturbance routine. 


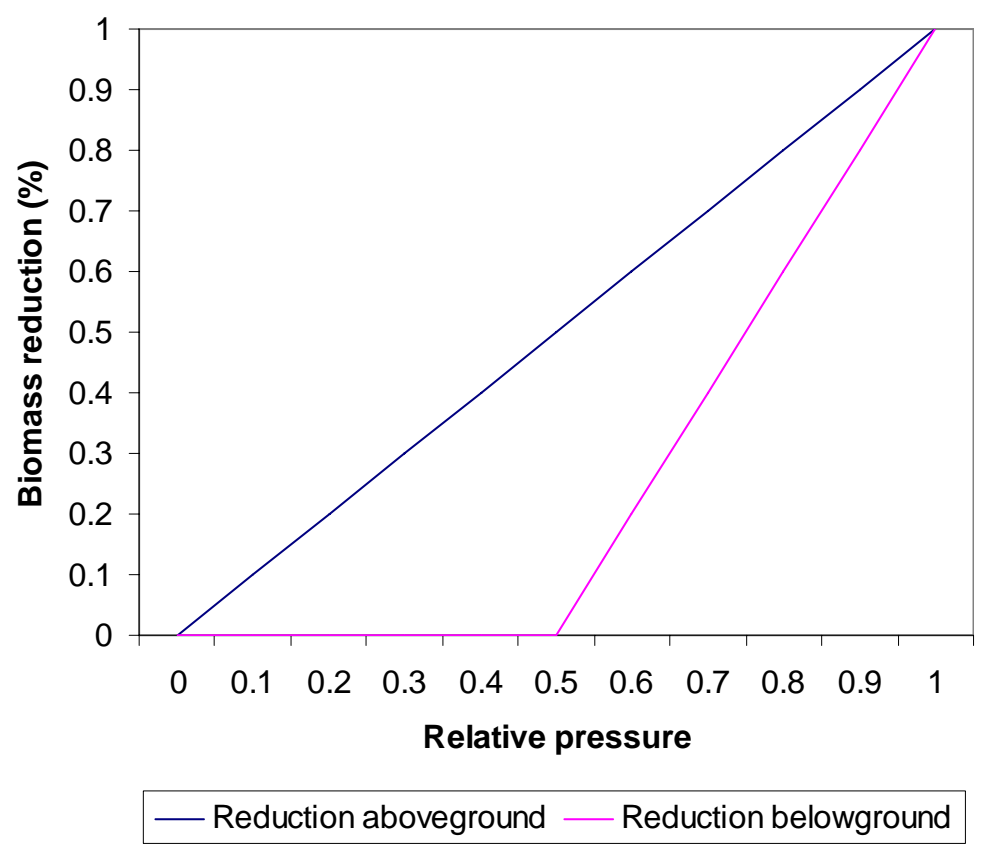

Figure D2. Damage to a plant in relation to the pressure exerted on the plant. 


\section{REPORT DOCUMENTATION PAGE}

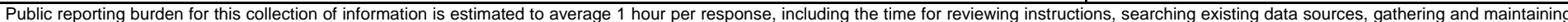

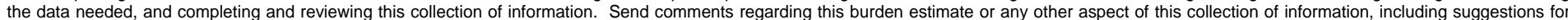

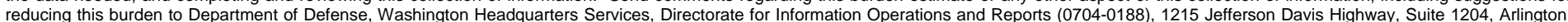

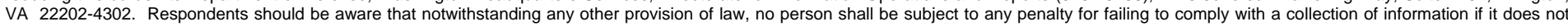
display a currently valid OMB control number. PLEASE DO NOT RETURN YOUR FORM TO THE ABOVE ADDRESS.
1. REPORT DATE (DD-MM-YYYY) 2. REPORT TYPE
November 2005
Technical Report

4. TITLE AND SUBTITLE

Simulation of Vegetation Recovery from Military Disturbances on Fort Bliss

6. AUTHOR(S)

Tamara Hochstrasser, Debra Peters, and Jeffrey Fehmi

\section{PERFORMING ORGANIZATION NAME(S) AND ADDRESS(ES)}

USDA-ARS Jornada Experimental Range

Box 30003, MSC 3 JER

New Mexico State University

Las Cruces, NM 88003

\section{SPONSORING / MONITORING AGENCY NAME(S) AND ADDRESS(ES)}

U.S. Army Engineer Research and Development Center

Construction Engineering Research Laboratory

2902 Newmark Drive

Champaign, Illinois 61826-9005

\section{DISTRIBUTION / AVAILABILITY STATEMENT}

Approved for public release; distribution is unlimited

\section{SUPPLEMENTARY NOTES}

\section{ABSTRACT}

This report covers two years of work by the Jornada Experimental Range Department at New Mexico State University and the U.S.Army ERDC/CERL. The overall goal of the project was to enhance the vegetation simulation modeling capabilities of Fort Bliss, Texas, for evaluating the effects of military disturbances on arid land vegetation. The aim of this work was to mechanistically predict shifts from one community type to another by determining primary linkages between community types.

\section{SUBJECT TERMS}

Disturbance

Fort Bliss

16. SECURITY CLASSIFICATION OF:

\section{a. REPORT}

$\mathrm{U}$

b. ABSTRACT

$\mathrm{U}$

c. THIS PAGE
Recovery

Vegetation

\begin{tabular}{|c|c|}
$\begin{array}{l}\text { 17. LIMITATION } \\
\text { OF ABSTRACT }\end{array}$ & $\begin{array}{c}\text { 18. NUMBER } \\
\text { OF PAGES }\end{array}$ \\
U & 88 \\
\hline
\end{tabular}

Vegetation modleing 19a. NAME OF RESPONSIBLE PERSON

19b. TELEPHONE NUMBER (include area code) 